http://kitaibelia.unideb.hu/

ISSN 2064-4507 (Online) • ISSN 1219-9672 (Print)

(C) Department of Botany, University of Debrecen, Hungary

26(2): 165-198.; 2021

DOI: $10.17542 /$ kit.26.165

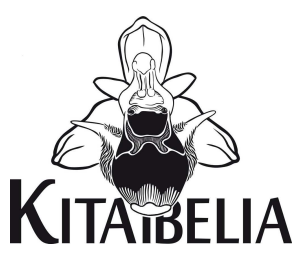

\title{
Adatok a sásfajok (Carex, Cyperaceae) előfordulásához a Dél-Nyírségben és környékén
}

\author{
DEMETER László* \& SzÉL László \\ Hortobágyi Nemzeti Park Igazgatóság, H-4024 Debrecen, Sumen u. 2.; *demeterlaszlo@hnp.hu
}

\section{Data on the occurrence of sedge species (Carex, Cyperaceae) in and around South Nyírség (East Hungary)}

\begin{abstract}
We provide floristic data on a total of 38 sedge species in the area of South Nyírség and its immediate surroundings. We also detected some populations of previously undescribed or rare species in the Hungarian Great Plain, such as Carex buxbaumii, Carex hartmanii, Carex umbrosa, and Carex paniculata. We report several new occurrences of species with little literature data from the area, such as Carex brizoides, Carex michelii, Carex pallescens, Carex elongata. However, during the last 13 years, we were not able to detect seven species previously mentioned in the literature. Herbarium data confirmed that some of the older Carex nigra occurrences for the area actually refer to Carex cespitosa. Based on herbarium data and the literature, we think that local data on Carex pairaei may largely refer to Carex divulsa subsp. leersii and/or Carex spicata. Contrary to many pieces of literature, Carex vulpina was not observed inside the sandy area.
\end{abstract}

Keywords: distribution, fens, flora mapping, Great Plain, herbarium revision, legally protected plants, sandy region

Összefoglalás - Összesen 38 sásfajról közlünk adatokat a Dél-Nyírség és közvetlen környezete területéről. Az Alföldön korábban le nem írt vagy ritkaságnak számító fajok néhány állományát is kimutattuk, mint a Buxbaum-sás (Carex buxbaumii), az északi sás (Carex hartmanii), az árnyéki sás (Carex umbrosa) és a bugás sás (Carex paniculata). Számos új előfordulást közlünk a térségből kevés irodalmi adattal rendelkező fajokról, például a rezgő sásról (Carex brizoides), sárgás sásról (Carex michelii), sápadt sásról (Carex pallescens), nyúlánk sásról (Carex elongata). A korábbi irodalmakban említett hét fajt viszont nem sikerült észlelnünk az elmúlt 13 év során. Herbáriumi adatok igazolták, hogy a fekete sás (Carex nigra) régebbi helyi adatainak egy része valójában a gyepes sásra (Carex cespitosa) vonatkozik. Herbáriumi adatok és az irodalom alapján úgy gondoljuk, hogy a berzedt sás (Carex pairaei) helyi adatai nagyrészt a tölgyes sásra (Carex divulsa subsp. leersii) és sulymos sásra (Carex spicata) vonatkozhatnak. Eltérően számos irodalmi adattól a rókasást (Carex vulpina) a homokvidék belsejében nem észleltük.

Kulcsszavak: Alföld, elterjedés, flóratérképezés, herbáriumi revízió, homokvidék, lápok, védett növényfajok

\section{Bevezetés}

A Nyírség sásflórájáról számos forrás áll rendelkezésünkre. Boros Ádámtól (BoRos 1932) monografikus összefoglalást olvashatunk a Nyírség flórájáról. Ehhez jelentős kiegészítést adott Soó Rezső és tanítványai munkássága (pl. Soó 1932, 1934, 1937a, 1939, 1942). Van néhány kisebb terület is a tájon belül, melyekről részletesebb feltárások is születtek, illetve 
cönológiai felvételek fajlistáit is közzéteszik. Példaként említhetjük RAPAICS (1916a) Debrecen flórájáról, NAGY et al. (1990) és MATUS \& PAPP (2001) bagaméri Daru-hegyekről, STANDOVÁR et al. in MAHUNKA (1991) Bátorligeti Őslápról, PAPP et al. (1996/97) penészleki legelőről, JAKAB \& LESKU (1996) piricsei Júlia-ligetről, MATUS \& PAPP (2003) hajdúsámsoni Martinkai-legelőről és vámospércsi Villongóról, KEVEY et al. $(2017 a, 2017 b)$ nyírségi erdőkről, illetve KARÁCSONYI (1995) és ADRELEAN \& KARÁCSONYI (2005) határon túli nyírségi területről készült munkáit. Vannak olyan közlemények is, melyek egy kisebb térség ritkább, illetve védett fajairól sorolnak fontos adatokat. Ide tartoznak például PAPP \& DuDás $(1988,1989,1990,1992)$ kutatási területünket, a Dél-Nyírséget érintő munkái. Létezik továbbá számos olyan közlemény is, ami szórványosabb adatokat jelez (pl. SIROKI 1965, TAKÁcS et al. 2016, KORDA et al. 2017, MATUS et al. 2019), illetve nem florisztikai jellegű munka, mely előfordulási adatokat tartalmaz (pl. MATUS et al. 2005, TöRÖK et al. 2009), és ismeretterjesztő jellegü kiadványokban is találunk sásokra vonatkozó adatokat (pl. PAPP 2003, PAPP 2010). Ezekkel együtt is elmondható, hogy a Nyírségben jó néhány kevéssé vagy egyáltalán nem kutatott, de florisztikai szempontból érdekes terület maradt, és persze van esély a jobban kutatott területeken is eddig nem észlelt fajok kimutatására. Ezt támasztják alá a Dél-Nyírség kistáján végzett természetvédelmi őri munkánk tapasztalatai. A térség lápjainak feltárása és ellenőrzése során többek között olyan az Alföldön nagy ritkaságnak számító sásfajokat találtunk, mint a Buxbaum-sás (Carex buxbaumii Wahlenb.), az északi sás (Carex hartmanii Cajander), az árnyéki sás (Carex umbrosa Host.) vagy a bugás sás (Carex paniculata L.). Ez a tapasztalat indította el a sásfajok adatainak több mint tíz évre visszanyúló gyüjtését. Közleményünk egyik célja tehát a ritkaságok adatainak közzététele. Másrészt azt láttuk, hogy Magyarország edényes növényfajainak elterjedési atlaszában (BARTHA et al. 2015), illetve annak online változatában (BARTHA et al. 2021) az általunk vizsgált térség sok faja igen alulreprezentált. Ezek között még olyan, egyébként gyakori fajok is akadnak, mint a parti sás (Carex riparia Curtis) és a korai sás (Carex praecox Schreb.). Továbbá számos, általunk számontartott fajt egyáltalán nem jelölnek a térképek, mint például a rezgő sás (Carex brizoides L.), nyúlánk sás (Carex elongata L.), sárgás sás (Carex michelii Host.), sápadt sás (Carex pallescens L.). Célunk tehát az atlasz hiányainak pótlása is. Ez kiegészül azzal, hogy adataink egy jó része más irodalmi említések megerősítéseként is szolgál, és az itt megadott kódok alapján közvetve azok is felkerülhetnek az elterjedési térképekre. Harmadrészt pedig kísérletet teszünk néhány korábban tisztázatlan taxonómiai és nevezéktani helyzetű, s ezért részben adathiányos vagy félreismert fajpár homályos helyi elterjedési viszonyainak megvilágítására. Ezek közé tartozik a rókasás (Carex vulpina L. s. str.) és berki sás (Carex otrubae Podp.), a fekete sás (Carex nigra (L.) Reichard) és gyepes sás (Carex cespitosa L.), valamint a berzedt sás (Carex pairaei F.W. Schultz) és tölgyes sás (Carex divulsa Stokes subsp. leersii (Kneucker) W. Koch) párosa.

\section{Terület és módszer}

A kutatási terület fóként a Dél-Nyírség kistájára terjedt ki, az alábbi települések határában: Álmosd, Bagamér, Debrecen, Fülöp, Hajdúbagos, Hajdúböszörmény, Hajdúhadház, Hajdúsámson, Hosszúpályi, Kokad, Létavértes, Mikepércs, Monostorpályi, Nyíracsád, Nyíradony, Nyírábrány, Nyírlugos, Nyírmártonfalva, Penészlek, Téglás, Újléta, Vámospércs. Nyírbéltekről mindössze egy adatot közlünk. Az Enumerációban felsorolt irodalmak is alapvetően erre a területre vonatkoznak. Fontos azonban kiemelni, hogy a települések határai nyugaton a Hajdúhátat és a Dél-Hajdúhátságot, délen a Berettyó-Kálló köze kistájat, keleten pedig az Érmelléki löszös hátat is érintik (DövÉNYI 2010). Ennek köszönhetően adataink egy kis része kitekint a szomszédos kistájakra is, ezek tehát nem homokterületről származnak. 


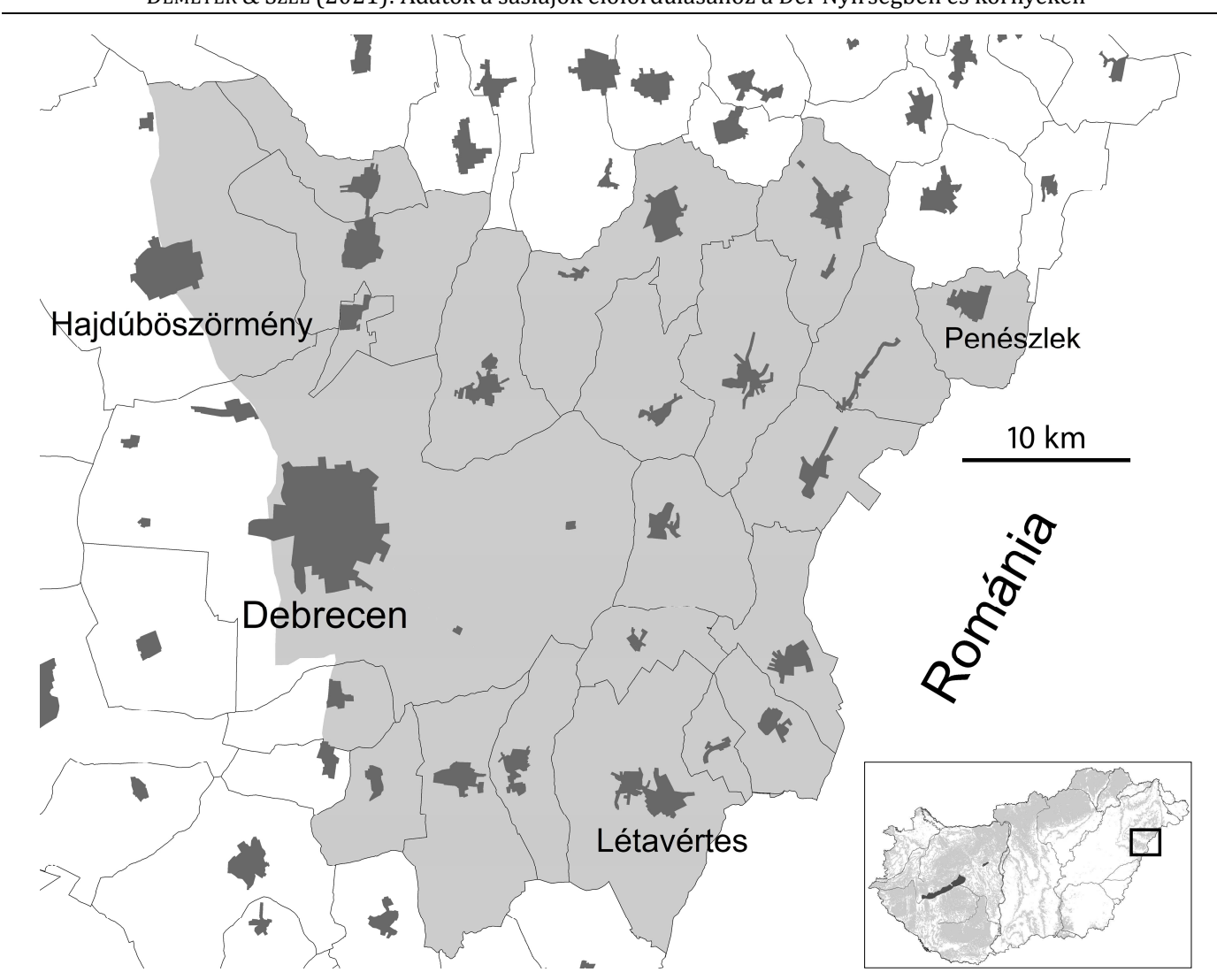

1. ábra A vizsgálati terület

Fig. 1 Study area

A fajok keresésére elsősorban a Hajdúsági Tájvédelmi Körzethez tartozó védett természeti területeken, Natura 2000 területeken, a földművelési miniszter által tájékoztató listában kihirdetett úgynevezett „ex lege” védett láppal érintett területeken, valamint kisebb részben a természetvédelmi őri munka során felkeresett, nem védett területeken került sor 2007-től 2021 júliusáig. A védett fajok GPS-szel rögzített részletes adatai a Hortobágyi Nemzeti Park Igazgatóság nyilvántartásába kerültek. A védett és ritkább fajokról - valamint esetenként a gyakoribbakról is - fényképeket készítettünk, herbáriumi példányokat nem gyüjtöttünk. A fotókból egy válogatás az elektronikus mellékletben látható.

Az egyes fajok adatainak itt közölt mennyisége természetesen nem tükrözi gyakoriságuk egymáshoz viszonyított arányát, bár van olyan fajpár, amellyel kapcsolatban később teszünk erre vonatkozó megállapítást. Általában jellemző, hogy a védett, illetve zsombékoló fajokat nagyobb valószínűséggel rögzítettük. Ellenpéldaként említhető a Carex acuta L., ami minden bizonnyal gyakoribb a területen, mint amit az itt közölt adataink száma sugall. A leggyakoribb fajok (pl. Carex hirta L., C. acutiformis Ehrh., C. riparia Curtis) adatainak rögzítésére kevésbé törekedtünk.

A lelőhelyek településhatáron belüli megnevezéséhez elsősorban a Magyarország Földrajzinév-tára térképét, az 1:10 000 méretarányú topográfiai térkép, valamint turistatérkép helyneveit használtuk. Helyenként zárójelben térképeken nem látható, de helyben használt neveket, vagy a terület pontosítását szolgáló és egyéb megjegyzéseket is feltüntettünk. Zárójelben adtuk meg az adott állományt megtaláló szerző monogramját az adat rögzítésének évével együtt. Ahol a megtaláló más személy, ott a teljes nevét kiírtuk. Szögletes zárójelben 
adtuk meg az előfordulási helyet lefedő KEF-kvadrát kódját. A kódokból összesített listát is készítettünk. Ebben vastagbetűs kiemeléssel jeleztük azokat, melyek a közlemény készítésekor nem szerepeltek Magyarország edényes növényfajainak online adatbázisában (BARTHA et al. 2021). Az enumerációban a sorszámozás és a nevezéktan KIRÁlY (2009) munkáját követi. Alfaji elkülönítést csak a Carex divulsa Stokes subsp. divulsa és Carex divulsa Stokes subsp. leersii (Kneucker) W. Koch esetén teszünk részben azért, mert LÁjER (2009) szerint pontos elterjedésük tisztázandó, valamint arra tekintettel, hogy a Carex divulsa subsp. leersii taxont az utóbbi időben már a $C$. divulsa-tól elkülönítve Carex leersii F.W. Schultz néven önálló fajként említik az irodalmak (MolinA et al. 2008a, 2008b, KoOPMAN 2015, KoOPMAN \& WiĘCŁAW 2017) (TURLAND et al. 2018). A vizsgált területre vonatkozó korábbi irodalmak megadásánál viszont ilyen alfaji elkülönítést nem tudtunk alkalmazni, ezért azokat a Carex divulsa Stokes név alatt listáztuk.

Nem tűztük ki célul a területre vonatkozó herbáriumi anyag teljes áttekintését. Néhány fajnál azonban olyan kérdések merültek fel, melyek megítéléséhez hasznos segítséget adott a Debreceni Egyetem Herbáriumában (DE) és a Magyar Természettudományi Múzeum Növénytárában (BP), illetve néhány esetben az ELTE Füvészkert herbáriumában (BPU) őrött lapok tanulmányozása, amit Demeter László végzett el. Az enumerációban tehát herbáriumi adatokat csak kivételesen közlünk. Ilyen a Carex hartmanii esetén eddig rejtve maradt két archív adat, valamint a Carex brizoides egy adata.

\section{Enumeráció}

\section{Carex remota $\mathrm{L}$.}

Lit.: KEVEY et al. (2017a) cönológiai felvételekben: Debrecen: Nagycsere, Nyírábrány: „Kiskőrises” és Mogyorós-erdő; egy flóratérképezési adata ismert Debrecen területéről (BARTHA et al. 2021), vélhetően Nagycseréről, a Kőrises Arborétumból.

Ined.: Debrecen: Nagycserei Kőrises Arborétum, az idős ligeterdőben kiterjedt állományokat alkot, valamint kissé keletre egy égeresen áthaladó árok mentén is szórványos [8496.4] (DL 2010-2020); Nyírábrány: Mogyorós-erdő, néhány tő a déli részén [8498.1] (DL 2020).

A Nyírségben igen ritka. Mi is csak a régi adatok megerősítését tudjuk közölni.

Az érintett KEF-kvadrátok listája: 8496.4, 8498.1

\section{Carex ovalis Gooden.}

Lit.: Soó (1932): Haláp; Soó (1934): Vámospércs, Penészlek: Pecestó, Debrecen: Pac-erdő; Soó (1937a): Debrecen (Haláp-Kalánhegy); Soó (1937b): Haláp-Nagycsere keményfás ligeterdőben, Peces-tó rekettyés füzlápban; SIROKI (1970): Újléta-Létavértes között, Debrecen: Sámsoni úti láp; PAPP et al. (1996/97): Penészlek: Veres-rét; MATUS \& PAPP (2001): Bagamér: Daru-hegyek; PAPP (2010): Álmosd: Daru-láp; MATuS et al. (2019): Bagamér, Daru-hegyek (Malom-gát) magkészletből; 6 flóratérképezési adata ismert Debrecen, Monostorpályi, Nyírmártonfalva, Penészlek területéről (BARTHA et al. 2021).

Ined.: Álmosd: Daru-láp [8597.2] (DL 2009); Bagamér: Gyula-tag [8597.2] (DL 2018); Debrecen: Nyárfa-lapos-dûlő [8596.4] (DL 2011), Paci-erdő [8596.1] (DL 2019), a Sámsoni út menti lápmaradvány [8496.1] (DL, 2011), Mézeshegyi-tölgyes [8596.3] (DL 2013), Erőslyuk [8496.2] (DL, 2017), Nagy-tag és Lukaháza (Hármashegyi-tölgyesek) tölgyeseiben [8496.2] (DL 2018, 2019, 2020), Rauchbauer-erdő és Hosszú-dűlő [8497.1] (DL 2018, 2019), Álló-hegy [8497.3] (DL 2018), Halápi-erdő [8596.2] (DL 2018) és [8597.1] (DL 2019), Haláp a Malomgáti-ér mentén [8496.4] (DL 2009), Martinkai-tölgyes Természetvédelmi Terület (a Panoráma úttól keletre) [8496.2] (DL 2021); Fülöp: Százholdas 
[8498.2] (DL 2019); Hajdúbagos: Földikutya Rezervátum [8596.3] (DL 2011); Hajdúhadház: Nagy-erdő [8396.1] (DL 2020); Hajdúsámson: Martinkai-legelő [8496.2] (DL 2018); Kokad: Konyári-Kálló völgye [8597.4] (DL 2018); Létavértes: Nagy-legelő és Csohos-tó [8597.3] (DL 2017); Mikepércs: Nyárfás-hegyi-legelő [8595.4] (DL 2011); Monostorpályi: Csík-gát tölgyese [8596.4] (DL 2018); Nyíracsád: Külső-Gút, Várhegyi-dűlő [8397.2] (DL 2018), Balkányi-rész [8397.4] (DL 2017); Nyíradony: Gúti-erdő [8397.2] (DL 2019); Nyírábrány: Káposztás-lapos [8497.2] (DL 2017), Dallárrész [8498.1] (DL 2017), Keszler-tag [8498.1] (DL 2018); Nyírmártonfalva: Szőlő-alja (Bagos-kert mellett) [8497.1] (DL 2020), Belső-Gút [8397.3] (DL 2021); Penészlek: Veres-rét [8398.4] (DL 2017); Újléta: Kis-erdő [8597.3] (DL 2019); Vámospércs: Bólya-dúlő [8597.2] (DL 2019).

Noha viszonylag kevés helyi adata volt ismert, a térségben elterjedt. Jellemzően kisebb csoportokban találtuk, főleg tölgyesekben, erdei nyiladékokon, erdőszéleken és helyenként nedves réteken.

Az érintett KEF-kvadrátok listája: 8396.1, 8397.2, 8397.3, 8397.4, 8398.4, 8496.1, 8496.2, 8496.4, 8497.1, 8497.2, 8497.3, 8498.1, 8498.2, 8595.4, 8596.1, 8596.2, 8596.3, 8596.4, 8597.1, 8597.2, 8597.3, 8597.4

\section{Carex praecox Schreb.}

Lit.: RAPAICS (1916b): Debrecen: Pallag; RAPAICS (1925): Debreceni Nagyerdő; Soó (1937b): Debrecen: Haláp-Nagycsere pusztai tölgyesekben; PAPP L. (1989): Debrecen: Nagyerdő; NAGY et al. (1990): Bagamér: Daru-hegyek; MATuS et al. (2005): Bagamér: Daru-hegyek; PAPP (2010): Kék-Kálló-völgy pontosabb helymegjelölés nélkül; MATUS \& PAPP (2003): Vámospércs: Villongó, Hajdúsámson: Martinkai-legelő; flóratérképezési adatok ismertek Debrecen, Hajdúbagos, Hajdúböszörmény, Hajdúhadház, Mikepércs, Nyírlugos, Nyírmártonfalva, Penészlek területéről (BARTHA et al. 2021).

Ined.: Bagamér: Malom-gát, Csonka-fűz [8597.2] (DL 2017, 2019); Debrecen: Álló-hegy [8497.3] (DL 2010-2016), Hosszú-dúlő, Nagy-tag [8497.1] (DL 2019), Nyárfa-lapos-dúlő [8596.4] (DL 2013), Nyárfa-lapos-dúlő [8596.2] (DL 2013), Paci-erdő [8596.1] (DL 2019), Szepes [8595.2] és [8595.4] (DL 2014), Sámsoni úti Bellegelő [8496.1] (DL 2017), Erőslyuk kaszáló [8496.2] (DL 2017), Vénházi játszótér a Panoráma úton, a Panoráma út vasúti átjárójánál, Cserei-dűlő északi részén, a Bál-hegy északi oldalán [8496.3] (DL 2017, 2018, 2019, 2020), Nagycserei Kőrises Arborétum déli oldalán, és Nagycsere a Panoráma úttól keletre [8496.4] (DL 2017, 2021), Bánki-erdőben több helyen [8596.2] (DL 2017, 2020), Dombostanyai-legelő [8396.3] (DL 2020); Hajdúbagos: Földikutya Rezervátum [8596.3] (DL 2011, 2017), Sárándi-Külső-határ [8695.2] (DL 2020); Hajdúböszörmény: Nagy-Nyerges [8295.1] (DL 2017), Városerdő (gázvezeték nyiladékán) [8395.4] (DL 2020); Hajdúhadház: Liget-legelő (lőtér) [8396.1] (DL 2021); Létavértes: Nagy-legelő [8597.3] (DL 2017); Hajdúsámson: Martinkai-legelő [8496.2] (DL 2013, 2017); Hosszúpályi: Fehértói-tározó északi végénél [8696.3] (DL 2011), Szabó-tiszta [8696.3] (DL 2011), Kis-Fehér-tó [8596.3] (DL 2020); Mikepércs: Nyárfás-hegyi-legelő [8595.4] (DL 2011, 2017); Monostorpályi: Monostorpályi-legelő keleti részén [8596.4] (DL 2010); Nyíracsád: Jónásrész buckája [8497.4] (DL 2017), Külső-Gút [8397.2] (DL 2020); Nyírábrány: KisMogyorós [8498.1] (DL 2020); Nyírmártonfalva: Büdös-kút (Gúti-erdő) [8397.3] (DL 2017), Bagos-kert [8497.1] (DL 2020); Téglás: Angolkert [8295.4] (DL 2019), Lápos-rét [8395.2] (DL 2019); Vámospércs: Bólya-dúlő sokfelé [8597.2] (DL 2017).

Általános elterjedtségéhez képest a vizsgált térségből viszonylag kevés adata volt.

Az érintett KEF-kvadrátok listája: 8295.1, 8295.4, 8395.2, 8395.4, 8396.1, 8396.3, 8397.2, 8397.3, 8496.1, 8496.2, 8496.3, 8496.4, 8497.1, 8497.3, 8497.4, 8498.1, 8595.2, 8595.4, 8596.1, 8596.2, 8596.3, 8596.4, 8597.2, 8597.3, 8695.2, 8696.3, 8696.4 


\section{Carex brizoides L.}

Lit.: KeveY et al. (2017a) cönológiai felvételben: Nyíradony: Gúti-erdő.

Herb.: Siroki Z. (1950. 04. 27.): Debrecen, Nagyerdő (DE).

Ined.: Bagamér: Nagy-erdő, kisebb-nagyobb foltokban [8597.2] (DL 2018); Debrecen: Mézeshegyi-tölgyes [8596.3] (DL 2013), Halápi-erdő, a Halápi-tározó déli végétől keletre fiatal tölgyesben [8596.2] (DL 2015), Erős-lyuk, egy tölgyesben kevés [8496.2] (DL 2017), Bánki-erdő, foltokban [8596.2] (DL 2017), Álló-hegy, 150-200 négyzetméternyi állomány [8497.3] (DL 2018), Halápi-erdő, 300 négyzetméteren [8596.2] (DL 2018), Nagyerdő, egy erdőfelújítási területen [8495.2] (DL, 2020); Hajdúhadház: Csereerdő északi részén tölgyesben [8395.2] (DL 2021)Nyírmártonfalva: Berek-szilas (Gúti-erdő) egy tölgyesben sok foltban, valamint a Gúti-ér mentén keményfás ligeterdő jellegű állományban [8397.4] (DL 2012, 2021); Nyíradony: Gömöri-gaz (Gúti-erdő) [8397.4] (DL 2012); Nyíracsád: KülsőGút északi részén egy tölgyes erdőrészletben [8397.2] (DL 2012); Nyírlugos: Fülöpi-oldal [8398.1] (DL 2016).

Meglehetősen ritka fajnak számít a Dél-Nyírségben, amit a korábbi adatok hiányossága is tükröz. Ennek ellenére kisebb-nagyobb foltjait felleltük a térség régi erdőtömbjeiben. Zárt homoki tölgyesekben és keményfás ligeterdőkben bukkantunk rá. Külön öröm, hogy a debreceni Nagyerdőben 70 év után meg tudtuk erősíteni Siroki Zoltán adatát. Magyarország edényes növényfajainak online adatbázisa (BARTHA et al. 2021) nem jelzi a vizsgált területről.

Az érintett KEF-kvadrátok listája: 8395.2, 8397.2, 8397.4, 8398.1, 8495.2, 8496.2, 8497.3, 8596.2, 8596.3, 8597.2

\section{Carex elongata L.}

Lit.: PAPP \& DUDÁS (1990, 1992): Nyírábrány: Nagy- és Kisláprét; PAPP (2010): Álmosd: Daru-láp.

Ined.: Álmosd: Daru-láp [8597.2] (DL 2009, 2017), Kék-Kálló [8597.4] (DL 2016); Debrecen: Hármas-hegy alja, fúzlápban több helyen [8496.4] (DL 2013, 2017); Nyíradony: Tivorány égerlápja [8397.2] (DL 2019); Nyírábrány: Kisasszony-rész, fúzlápban a KisVillongó-ér mentén [8497.4] (DL 2016), Káposztás-lapos [8497.2] (DL 2019); Nyírmártonfalva: Cseres-hegy alatti égerlápban néhány [8497.1] (DL 2017); Létavértes: Nagylegelő égerlápja (Toszorka-rét) [8597.3] (DL, SZL 2012).

Ritka sás a térség égerlápjaiban és füzlápjain. A nagyobb füzlápok még bizonyára több szórványos állományt rejtenek. Magyarország edényes növényfajainak online adatbázisa (BARTHA et al. 2021) nem jelzi a vizsgált területről.

Az érintett KEF-kvadrátok listája: 8397.2, 8496.4, 8497.1, 8497.2, 8497.4, 8597.2, 8597.3, 8597.4

\section{Carex divulsa Stokes}

Lit.: RAPAICS (1916a) a debreceni Nagyerdőben gyűjtötte (C. leersii néven); Soó (1934): Debrecen: Hajdúszentgyörgy, Pac, valamint Sáránd és Hajdúbagosi-erdő; Soó (1937b): Debreceni Nagyerdő; Soó (1939) és Soó (1942): Hajdúhadház; Aszód (1936): Debreceni Nagyerdő; KEVEY et al. $(2017 a, b)$ cönológiai felvételekben a subsp. divulsa alfajra vonatkozóan: Debrecen: Nagyerdő, Monostori-erdő, Nagycsere, Halápi-erdő, Nyíradony: Gúti-erdő, Nyírábrány: Mogyorós-erdő; flóratérképezési adatok ismertek Bocskaikert és Hajdúhadház területéről (BARTHA et al. 2021).

\subsection{Carex divulsa Stokes subsp. divulsa}

Ined.: Bagamér, Nagy-erdő [8597.2] (DL 2020); Bocskaikert, Nagy-erdő [8396.3] (DL 2020); Debrecen: Nagyerdő, foltokban [8495.2] (DL, 2010), Nagycsere, Kőrises Arborétum [8496.4] (DL 2019), Mézeshegyi-tölgyes [8596.3] (DL 2013), Apafai-erdő [8496.1] (DL 2020), Haláp, a falu melletti ligeterdőkben szórványos [8496.4] (DL 2017, 2020), Monos- 
tori-erdő [8395.4] és [8495.2] (DL 2017), Szentgyörgyi-erdő (C. sylvatica mellett) [8395.4] (2020), Bánki-erdő, több helyen [8596.2] (DL 2020), Cserei-dűlő, a Nagycserei Erdészlaktól északra [8496.3] (2020); Hajdúbagos: Sűrű tisztája [8596.3] (DL 2018); Hajdúhadház: Csereerdő (Bocskaikert mellett) [8395.2] (DL 2019), Nagy-erdő [8396.1] (2020); Hajdúsámson: Savós-Kút (vagy Savós-Gút) és Tiszti lakótelep mellett [8396.3] (DL 2020); Monostorpályi: Csík-gát tölgyese, kisebb foltban [8596.4] (DL, 2018); Nyíracsád: Külső-Gút [8397.4] (DL 2012), Jónásrész [8497.2] (DL 2019); Nyírmártonfalva: Megyerihegy keleti oldalán (Belső-Gút) [8397.3] (DL 2012).

Ez a taxon a Dél-Nyírségben a keményfás ligeterdőkre és a zárt homoki tölgyesek nedvesebb és árnyasabb részeire jellemző. Igényei hasonlóak a Carex sylvatica-éhoz, amivel gyakran együtt fordul elő. A régi erdőtömbökben szórványos.

Az érintett KEF-kvadrátok listája: 8395.2, 8395.4, 8396.1, 8396.3, 8397.3, 8397.4, 8495.2, 8496.1, 8496.3, 8496.4, 8497.2, 8596.2, 8596.3, 8596.4, 8597.2

\subsection{Carex divulsa Stokes subsp. leersii (Kneucker) W. Koch}

Ined.: Bocskaikert, Nagy-erdő [8396.3] (DL 2020); Debrecen: Nagyerdő, igen sok, gyakran a nyiladékokon [8495.2] (DL 2010-2020), Apafai-erdő [8495.2] (DL 2019) és [8496.1] (2020), Martinkai Tölgyes Természetvédelmi Terület (a Zsuzsi Vasút martinkai megállója közelében) [8496.2] (DL 2018), Nagycsere, a Sámsoni földút menti tölgyesekben [8496.4] (DL 2019), Monostori-erdő, sok helyen [8395.4] (DL 2017), Cserei-dúlő [8496.3] (2020), Nagycsere, a Sámsoni földút menti tölgyesekben [8496.4] (DL 2020), Halápi-erdő és Bánki-erdő több részében [8596.2] (DL 2019, 2020); Hajdúbagos: Sürü tisztája [8596.3] (DL 2020); Hajdúböszörmény, Városerdő több pontján [8395.2] [8395.3] (DL 2019, 2020); Hajdúhadház: Csereerdő (Bocskaikert mellett) sokfelé [8395.2] és [8395.4] (DL 2019), Nagy-erdő [8396.1] (2020); Hajdúsámson: Savós-Kút (vagy Savós-Gút) [8396.1] (DL 2018); Monostorpályi: Csík-gát tölgyese [8596.4] (DL 2018); Nyírmártonfalva: Berekszilas a gúti ér mentén [8397.4] (DL 2021); Téglás: Angolkert [8295.4] (DL 2017).

Fontos kitérnünk arra, hogy véleményünk szerint a Debrecen-Haláp ligetéből, a Hajdúbagosierdőből (Soó 1932, 1934), a debreceni Nagyerdőből (PAPP 1989), és a penészleki Veres-rétről (PAPP et al. 1996/97) C. pairae F. Schultz, illetve C. pairae néven közölt irodalmi adatok minden bizonnyal erre a taxonra, vagyis a tölgyes sásra vonatkoznak, nem pedig a berzedt sásra (Carex pairaei F.W. Schultz), hiszen Soó (1973) összefoglaló műve és Felföldy (2002) Sáshatározója még a C. pairaei (vagy pairae) alfajaként kezelte ezt a formát, és nyírségi előfordulását nevesítik is. Az időpontokat figyelembe véve feltételezzük, hogy ugyanez a helyzet Papp Mária 2002-es penészleki, valamint Török Péter 2004-es hajdúböszörményi és debreceni flóratérképezési adataival (BARTHA et al. 2021). Ebben persze megfelelő herbáriumi példányok hiányában nem lehetünk minden esetben biztosak, hiszen a sások e Phaestoglochin szekcióként számontartott csoportja, melybe az említett taxonok tartoznak, igen bonyodalmas taxonómiai és nomenklatúrai múltra tekint vissza (KooPMAN \& WiĘCŁAW 2017). Csak hazai példaként említjük, hogy SIMON (2000) határozókönyve a berzedt sást még „C. muricata L. subsp. lamprocarpa Čelak." néven tárgyalta. Feltevésünket azonban némileg alátámasztja a Carex pairaei-ként nyilvántartott lapok vizsgálata a Debreceni Egyetem Herbáriumában. A Soó Rezső Herbáriumban a Dél-Nyírségen kívüli területekről számos $C$. pairaei feliratú lap található, melyeken megítélésünk szerint a legtöbb esetben tölgyes sás (Carex divulsa subsp. leersii) látható. Ezek közül számos Felföldy Lajostól származik. Neki a vizsgált területről, Debrecenből (1940) is van egy példánya. Felföldi a lapokon konzekvensen használta az általa írt Sás-határozó taxonómiai szemléletét. A Siroki Zoltán által Józsán (1958), Debrecenben (1976) és Nagylétán (1984) gyűijtött példányok viszont mind sulymos sásnak (Carex spicata) bizonyultak, hasonlóan Farkas Roland Jónás-részről (2000) származó példányához. A Magyar Természettudományi Múzeum Növénytárának gyűjteményében található nyírségi lapok megítélésünk szerint szintén a feltevésünket támasztják alá. 
A subsp. leersii a kevésbé nedves tölgyesek világosabb részein, gyakran a nyiladékokon található meg. Átmeneti jellegű élőhelyen a subsp. divulsa-val kevert állományaik is előfordulnak. A hajdúhadházi Csereerdőben arra is volt példa, hogy vegyes sáscsomót alkottak.

Az érintett KEF-kvadrátok listája: 8295.4, 8395.2, 8395.3, 8395.4, 8396.1, 8396.3, 8397.4, 8495.2, 8496.1, 8496.2, 8496.3, 8496.4, 8596.2, 8596.3, 8596.4

\section{Carex spicata Huds.}

Lit.: Soó (1932): Haláp ligetében; Soó (1934): Debrecen: Haláp, Nagycsere-Martinka, Bánk, Pac, Hajdúszentgyörgy, valamint Külsőguth-erdő; Soó (1937a): Hajdúbagosi-erdő, Gutherdő; Soó (1937b): Debreceni Nagyerdő; Soó (1939): Haláp: Pipóhegy. A fenti irodalmakban Carex contigua néven; TAKÁcs et al. (2016): Monostorpályi: Damjanich utca vége; KEVEY et al. (2017a) cönológiai felvételben: Nyírábrány: „Kiskőrises”; flóratérképezési adatok ismertek Bocskaikertből, Hajdúhadházról, Mikepércsről, Debrecenből, Álmosdról, Bagamérból (BARTHA et al. 2021).

Ined.: Bagamér: Silye-rét [8497.4] (DL 2020), Nagy-erdő, Csonka-füz (ezüsthársas tölgyes) [8597.2] (DL 2020); Bocskaikert: Nagy-erdő [8396.3] (DL 2020); Debrecen: Nyárfa-laposdűlő [8596.2] és [8596.4] (DL 2013), Erős-lyuki kaszáló, Lukaháza [8496.2] (DL 2017, 2019), Nagy-tag [8496.2] (DL 2018), Cserei-dűlő (Csereerdő) [8496.3] (DL 2017), Fancsika II. tárolótól északkeletre tölgyes [8496.3] (DL 2018), Bodzás-tározó melletti rét és tározótöltés [8496.4] (DL 2013, 2017), Hosszú-dúlő [8497.1] (DL 2019), Álló-hegy és a szomszédos rét [8497.3] (DL, 2017, 2018), Paci-erdő [8596.1] (DL 2019, 2020), Bánkierdő [8596.2] (DL, 2018, 2020), Halápi-erdő és a Halápi-tározó közelében [8596.2] (DL, 2018, 2020), Haláp falu mellett (ligeterdőben) [8496.4] (DL 2020), Halápi-erdő („nyíres tölgyes") [8597.1] (DL 2017), Nagycsere (a Zsuzsi Vasút Martinka megállójától délre több helyen), a Kőrises Arborétumban és a sámsoni földút menti tölgyesekben [8496.4] (DL 2020), a Bál-hegy északi oldalán, a Bál-tiszta déli részén, a Cserei-dűlőben [8496.3] (DL 2020), Rauchbauer-erdő [8497.1] (DL 2020), Mézeshegyi-tölgyes [8596.3] (DL 2020), Monostori-erdő [8395.4] (DL 2020); Hajdúsámson: Martinkai-legelő [8496.2] (DL 2013); Hajdúbagos: Sưrű tisztája [8596.3] (DL 2020); Hajdúhadház: Csereerdő [8395.2] (DL 2020), Nagy-erdő, Liget-legelő (lőtér) [8396.1] (DL 2020, 2021); Hosszúpályi: Hosszú-gaz [8596.4] (DL 2020); Monostorpályi: Bónis-hegy a Rapi-tanya mellett, Monostorpályilegelő északi része, Csík-gát [8596.4] (DL 2017, 2019, 2020); Nyíracsád: Kis-tag (kubikgödrös) [8397.4] (DL 2017), Külső-Gút [8397.4] (DL 2017), Várhegyi-dúlő [8397.2] (DL 2020); Nyíradony: Gúti-erdő [8397.2] (DL 2021); Nyírábrány: Káposztás-lapos északi és déli vége [8497.2] és [8497.4] (DL 2017), Hanelek [8498.2] (DL 2020), Mogyorós-erdő [8498.1] (DL 2020); Nyírmártonfalva: Ártánházi-szántó, Belső-Gút [8397.3] (DL 2017, 2021), Berek-szilas [8397.4] (DL 2021); Vámospércs: Bólya-dűlő déli részének kis tölgyese [8597.2] (DL 2019).

A Phaestoglochin szekció elterjedt faja a vizsgált területen. Ehhez képest meglehetősen alulreprezentált Magyarország edényes növényfajainak online adatbázisában (BARTHA et al. 2021). Erdők világosabb foltjain, erdőszéleken és mezofil gyepekben egyaránt előfordul.

Az érintett KEF-kvadrátok listája: 8395.2, 8395.4, 8396.1, 8396.3, 8397.2, 8397.3, 8397.4, 8496.2, 8496.3, 8496.4, 8497.1, 8497.2, 8497.3, 8497.4, 8498.1, 8498.2, 8596.1, 8596.2, 8596.3, 8596.4, 8597.1, 8597.2, 8696.4

\section{Carex vulpina L.}

Lit.: RAPAICS (1916a): Pallag; Soó (1938): Caricetum vulpinae felvételek Halápról; SIROKI (1970): Újléta-Létavértes között; PAPP et al. (1996/97): Penészlek: Veres-rét; MATus \& PAPP (2003): Vámospércs: Villongó, Hajdúsámson: Martinkai-legelő; PAPP (2010): KékKálló-völgy pontosabb helymegjelölés nélkül; flóratérképezési adatok ismertek Álmosd, 
Bagamér, Debrecen, Fülöp, Hajdúbagos, Hajdúhadház, Hajdúsámson, Monostorpályi, Nyíradony, Nyírábrány, Létavértes, Újléta, Penészlek területéről (BARTHA et al. 2021).

Ined.: Debrecen: Szepes vasúti megállótól kissé nyugatra [8595.2] (DL 2012); Hajdúböszörmény: Fekete-dűlő [8295.1] (DL 2017); Hosszúpályi: Kis-Fehér-tó [8696.3] (DL 2010); Mikepércs: Nyárfás-hegyi-legelő [8595.4] (DL 2011).

A rókasás előfordulását jóval ritkábbnak véljük a térségben, mint az irodalmi adatok felületes szemlélete alapján várható lett volna. Észleléseink lényegében nem is a nyírségi homokterületről származnak, hanem a szomszédos löszös, illetve szikes talajú vidékekről. A mikepércsi Nyárfás-hegyi-legelő ugyan formálisan a Dél-Nyírséghez tartozik, de ott is a kötött, szikes talajú részén észleltük a fajt. A régebbi adatok jelentős része véleményünk szerint a berki sásra vonatkozik (lásd C. otrubae).

Az érintett KEF-kvadrátok listája: 8295.1, 8595.2, 8595.4, 8696.3

2602. Carex otrubae Podp.

Lit.: MATUS \& PAPP (2003): Vámospércs: Villongó, Hajdúsámson: Martinkai-legelő. Mivel Soó (1973) a Carex vulpina var. tenuior alakot e fajhoz sorolja, valamint a ligeterdei Carex vulpina adatokat is, ezért itt említjük a következőket: Soó (1932): Hajdúböszörményi út mellett; Soó (1934): Tócómente, Haláp; Soó (1937b): Haláp-Nagycsere keményfás ligeterdőben; flóratérképezési adatok ismertek Debrecen, Bocskaikert, Fülöp, Hajdúhadház, Hajdúsámson, Mikepércs, Létavértes, Penészlek, Vámospércs területéről (BARTHA et al. 2021); Soó \& MátHÉ (1938) Debrecen: „Tocópart”.

Ined.: Bagamér: Nagy-erdő [8597.2] (DL 2018); Debrecen: Nagycserei Kőrises Arborétum [8496.4] (DL 2010, 2016), Nyárfa-lapos-dűlő [8596.4] (DL 2011, 2013) és [8596.2] (DL 2013), Bellegelő (a repülőtértől délre és a Mikepércsi út keleti oldalán a Hosszúpályi út leágazásától északra levő gyepen is sok) [8595.2] (DL 2013, 2015) , Bodzás-tározótól keletre és nyugatra eső gyepeken [8496.4] (DL, 2013, 2017, 2018), Halápi-erdő (Álló-hegy melletti rét) és az erdőtömbben délebbre is [8497.3] [8596.2](DL 2017, 2020), Hosszúdűlő [8497.1] (DL 2019), Nagy-tag [8496.2] (DL 2020), Cserei-dúlő (a Nagycserei Erdészlaktól északra), a Bál-hegy mellett, a Bál-tiszta déli részén [8496.3] (DL 2020), Nagycsere (a Panoráma út keleti oldalán) [8496.4] (DL 2020), Haláp ( a falu melletti ligeterdőben) [8496.4] (DL 2020); Fülöp, Nagy-part [8398.4] (DL 2020), Zöld Marci-legelő [8498.2] (DL 2020); Hajdúbagos: Sárándi-Külső-határ [8695.2] (DL 2020); Hajdúsámson: Martinkailegelő [8496.2] (DL 2013, 2017), Diósvári-dúlő [8396.3] (DL 2020); Hosszúpályi: Fehértói-tározó északi végénél [8696.3] (DL 2011); Létavértes: Falu-rét [8697.1] (DL 2010), Kossuth-kert melletti égerláp (Toszorka-rét) [8597.3] (DL 2017), Böcsöntő (zsilip környékén) [8597.3] (DL 2017); Nyíracsád: Kis-tag (kubikgödrös) [8397.4] (DL 2017); Nyírábrány: Káposztás-lapos [8497.2] (DL 2017), Mogyorós-erdő [8498.1] (DL 2020); Nyírmártonfalva: Berek-szilas [8397.4] (DL 2021); Téglás: Angolkert [8295.4] (DL 2020), Lápos-rét [8395.2] (DL 2020); Vámospércs Kőrises-dülő [8497.2] (DL 2017).

A Carex otrubae jelenléte gyakoribb volt, mint az irodalmi előfordulása. Ez természetesen részben abból ered, hogy a régi irodalmak keletkezése idején a rókasástól még nem különítették el hazánkban (FELFÖLDY 2002). JÁVORKA (1962) növényhatározójában például a Carex otrubae még semmilyen néven nem szerepel. MÉsZÁROS F.-NÉ DRASKOVITS (1968) viszont már azt állapította meg, hogy az általa megvizsgált hazai Carex vulpina exsiccata-példányok nagy része Carex otrubae-nak bizonyult. A vizsgált anyagról készített elterjedési térképe a DélNyírségből csak ezt a fajt mutatta. Soó (1973) a korábban Carex vulpina var. tenuior néven közölt adatait is ehhez a fajhoz tartozónak vélte, illetve a ligeterdőből leírt $C$. vulpina adatokat is ide sorolta. Ezt megerősíti, hogy Felföldy Lajos ennek megfelelően revideálta a Magyar Természettudományi Múzeum Növénytárában található Carex vulpina var. tenuior feliratú bátorligeti példányát Carex cuprina (Sándor) Nendtv. szinonim néven. A MÉSZÁRos F.-NÉ DRAS- 
KOVITS (1968) által végzett revíziónak köszönhetően a Debreceni Egyetem Soó Rezső Herbáriumában a vizsgált térségből csak Carex otrubae példányok vannak, $C$. vulpina pedig nincs (TAKÁCS et al. 2014). Átnéztük a Siroki Zoltán Herbáriumban a kutatott területről származó lapokat. Ezeket Siroki gyüjtötte 1958. 06. 04-én Józsán és 1984. 05. 31-én debreceni vizenyős réten és nedves kaszálón. Mindegyiket Carex otrubae-ként határoztuk. A két faj előfordulási viszonyaira tehát jelentősen eltérő képet kaptunk, mint amit a Magyarország edényes növényfajainak online adatbázisa (BARTHA et al. 2021), illetve az irodalmi adatok sugallnak.

Az érintett KEF-kvadrátok listája: 8295.4, 8396.3, 8397.4, 8398.4, 8496.2, 8496.3, 8496.4, 8497.1, 8497.2, 8497.3, 8498.1, 8498.2, 8595.2, 8596.2, 8596.4, 8597.2, 8597.3, 8695.2, 8696.3, 8696.4, 8697.1

2603. Carex paniculata L.

Lit.: RAPAICS (1916b): Debrecen: Haláp; Soó (1933) szerint nincs a Nyírségben; PAPP (2010): Kokad határában.

Ined.: Bagamér: Fehérföld-sziget, 1 zsombék [8597.2] (SZL 2014); Fülöp: Tótfalu, 1 zsombék [8498.1] (DL SZL 2011); Kokad: Álmosd-Kokadi-tározó, összesen 350 zsombék [8597.4] (SZL DL 2010, 2011, 2016), Daru-láp, 12 zsombék [8597.4] (DL SZL 2009, 2011, 2014); Létavértes: Falu-rét, 4 zsombék [8697.1] (SZL 2012); Nyírábrány: Teleki-legelő, 2 zsombék a nyírlápban [8498.1] (DL SZL 2011). Ez a két zsombék 2020-ra elpusztult, feltehetően a szárazság miatt.

A bugás sásról Soó (1933) azt írta, hogy nem él a Nyírségben, hanem itt a „C. paradoxa” (ma elfogadott nevén C. appropinquata) helyettesíti, vagyis szerinte RAPAICs (1916b) tévesen írta le Halápról. A kokadi Daru-lápról, valamint Bagamér, Nyírábrány és Fülöp határából származó adataink alapján ez a kép annyiban módosítandó, hogy a faj csekély mennyiségben előfordul a Nyírség déli részén. Ráadásul 2004-ből ismert a Délkelet-Nyírségben található Ömböly határából Lesku Balázs flóratérképezési adata is (BARTHA et al. 2021). Fontos megjegyezni, hogy a létavértesi Falu-rét 4 zsombékja a Berettyó-Kálló köze kistájra, az Álmosd-Kokaditározónál, illetve a Bagaméri-ér álmosdi szakaszán található nagyobb állományok pedig az Érmelléki löszös hát területére esnek. Az Érmelléki löszös hát déli pereménél, a BerettyóKálló köze kistájon egyébként régóta ismert egy jelentős állománya a Pocsaj határában található Töviskes lápjában (LÁJER 1998). Mivel ez az adat nem szerepel a Magyarország edényes növényfajainak elterjedési atlasza online adatbázisában sem, itt megadjuk KEF kvadrátjának kódját [8697.3].

Az érintett KEF-kvadrátok listája: 8498.1, 8597.2, 8597.4, 8697.1, 8697.3

2604. Carex appropinquata Schumach.

Lit.: Soó (1932, 1938, 1940): Haláp; Soó (1934): Martinka, Debrecen-Hajdúsámson, Penészlek-Bánháza; Soó (1939): Újléta-Bagamér; PAPP \&Dudás (1990): Nyírábrány, Nagyláprét, Legelőszél, Vámospércs-Nyíracsád, Jónásrész, Penészlek, Veres-rét, Bergel tagok; SIROKI (1970): Újléta-Létavértes között, Debrecen, Sámsoni úti láp; PAPP et al. (1996/97): Penészlek, Veres-rét; PAPP (2003): Vámospércs-Nyíracsád, Jónás rész; PAPP (2010): KékKálló-völgy pontosabb helymegjelölés nélkül; KoRDA et al. (2017): Álmosd: Daru-láp; DEMETER (2018): Debrecen: Haláp-szél; Nyírábrány: Kis-mogyorós. Magyarország edényes növényfajainak online adatbázisa herbáriumi adatokat közöl még Debrecen, Bagamér és Penészlek határából (BARTHA et al. 2021).

Ined.: Álmosd: Daruláp, kevés [8597.2] (DL SZL 2009, 2012, 2016), Kálló-völgy, szórványos [8597.4] (SZL DL 2011, 2016); Bagamér: Csonka-fűz [8597.2] (SZL 2010), Silye-rét [8497.4] (SZL DL 2015, 2016); Debrecen: Haláp-szél, több foltban szórványos állományok [8497.1] (DL SZL 2011), Halápi-tározó északi végénél levő lápban 14 zsombék [8496.4] (DL 2013), Hosszú-dűlő, 43 zsombék lápra ültetett égeresben [8497.1] (DL 2010); Fülöp: 
Hunyadi-szállás, 10 zsombék [8398.3] (DL SZL 2011), Marci-legelő, néhány zsombék [8498.2] (DL SZL 2009, 2014), Nagy-part, néhány zsombék [8398.4] (DL 2015), Nemestag, a zsombékok a területen kisebb-nagyobb csoportokban elszórtan fordulnak elő (legnagyobb csoport 20 zsombék) [8398.4] (DL SZL 2015), Százholdas, kevés [8498.2] (DL SZL 2010), Tótfalu, több mint 100 zsombék szórványosan, de többségük igen kicsi [8498.1] (DL SZL 2011, 2015), Windics-rész, a zsombékok a területen kisebb-nagyobb csoportokban elszórtan fordulnak elő (legnagyobb csoport 59 zsombék) [8398.3] (DL 2015); Kokad: Daru-láp, minimum 205 zsombék [8597.4] (SZL DL 2009, 2011, 2014, 2015, 2016); Létavértes: Falu-rét, kisebb csoportok az északi részen [8697.1] (SZL 2012), Nagy-Ócsa, kevés [8597.3] (SZL 2010); Nyírábrány: Dallár-rész, szórványos lápréti kaszálón [8498.1] (DL 2010-2017), Káposztás-lapos, néhány zsombék gyepes sás között [8497.2] (DL 2014), Keszler-tag, 5 zsombék nyírláp szélén [8498.1] (DL 2010), Kövendilegelő, 33 zsombék [8497.4] (DL 2009, 2014, 2015), Ludas (Konyári-Kálló mentén), 13 zsombék [8497.4] (SZL 2010, 2012), Teleki-legelő, szórványos zsombékok és csoportok több lápmederben [8498.1] (DL 2014); Nyíracsád: Jónásrész, néhány zsombék [8497.2] (DL 2009), Rikács, a zsombékok a területen kisebb-nagyobb csoportokban elszórtan fordulnak elő (legnagyobb csoport 27 zsombék) [8398.3] (DL 2015); Nyírbéltek: Malom-gát, egy lápfoltban a 40-50 zsombékot is elérő csoportokban, egy északabbi területen mindössze 2 zsombék [8398.2] (DL SZL 2012); Nyírmártonfalva: Cseres-hegy alja égerláp, 1 zsombék [8497.1] (DL 2015), Lapos-dűlő, több állomány lápokban és kaszált lápréteken [8497.1] (DL SZL 2010,2011), Reviczki-rész, 2 zsombék [8397.3] (DL 2011); Penészlek: Dózer-tó melletti láp, szórványos [8398.4] (DL SZL 2010, 2011, 2016), Kaszáló-dűlő, 18 zsombék [8398.4] (DL 2011), Pócsi-sziget, 15 zsombék [8399.3] (DL SZL 2010), Veres-rét, több lápmederben szórványos [8498.2, 8398.4] (DL SZL 2009-2017); Újléta: Bank-lapos, néhány foltban [8597.1] (SZL 2012, 2016), Nagy-Ócsa, kevés [8597.3] (SZL 2010), Steiertag délebbi lápjain (Monostori-ér mente) szórványos, de 40 zsombékos csoport is van [8597.1] (DL SZL 2010, 2011, 2016); Vámospércs: Bólya-dűlők, a Monostori-ér forrásági lápjaiban sokfelé szórványos [8597.1, 8597.2] (DL SZL 2011-2016).

A védett fajok közül legtöbb adatot a rostostövű sásról gyűjtöttünk. Elterjedése a térségben látványosan követi a fő vízfolyások széles völgyeinek lefutását. Ez leginkább a Konyári-Kálló völgyében gyöngysor módjára sorjázó állományokon feltűnő, de kicsit nyugatabbra a Monostori-ér délibb völgyén is megfigyelhető.

Az érintett KEF-kvadrátok listája: 8397.3, 8398.2, 8398.3, 8398.4, 8399.3, 8496.4, 8497.1, 8497.2, 8497.4, 8498.1, 8498.2, 8597.1, 8597.2, 8597.3, 8597.4, 8697.1

\section{Carex disticha Huds.}

Lit.: Soó (1934): Debrecen: Haláp, Bedecs, Pac; Penészlek: Peces-tó; Soó (1937b): Penészlek: Peces-tó; Soó (1938): Caricetum intermediae felvételek Halápról; Soó (1939): Újléta, Bagamér; SIRокI (1965): Hajdúszentgyörgy; SIRокі (1970): Újléta-Létavértes között; Debrecen: Sámsoni úti láp; PAPP (2010): Kék-Kálló-völgy pontosabb helymegjelölés nélkül; Takács et al. (2016): Létavértes: Falu-rét; további flóratérképezési adat ismert Nyíracsád területéről (BARTHA et al. 2021).

Ined.: Álmosd: Csuszkajó a Bagaméri-ér mentén [8597.4] (SZL, DL 2019); Debrecen: Nyárfa-lapos-dúlő [8596.4] (DL 2013), Tócó-völgy, nagy állomány [8395.3] (DL 2017), Nagycserei Kőrises Arborétum déli oldalán 100 négyzetméter [8496.4] (DL 2017), Hármashegy alja, nagy foltokban [8496.4] (DL 2018), Bodzás-tározótól keletre és nyugatra levő kaszálókon [8496.4] (DL 2018), Halápi-tározótól délre eső réten [8596.2] (DL 2019); Fülöp: Forduló-dűlő több rétjén [8398.3] (DL 2011), Béketelep keleti oldalán [8498.2] (DL 2011), Százholdas [8498.2] (DL 2019); Hajdúböszörmény: Nagy-Nyerges [8295.1] (DL 2017), Tócó-völgy, szórványos [8395.3] (DL 2017); Hajdúsámson: Jánostava-dűlő 
[8496.1] (DL 2016); Kokad: Konyári-Kálló völgye [8597.4] (DL 2018); Létavértes: Falu-rét [8697.1] (DL 2010); Monostorpályi: Lapos-dűlő [8696.2] (DL 2019); Nyíracsád: Jónásrész [8497.2] és [8497.4] (DL 2011,2017, 2018); Nyírmártonfalva: Ártánházi-szántó [8397.4] (DL 2017); Penészlek: Veres-rét, szórványos [8498.2] (DL 2017), Pántos-rátai-rétek területén 2 nagyobb foltban [8399.3] (SZL 2013); Téglás: Lápos-rét [8395.2] (DL 2019).

A térségben elterjedt faj, de állományai általában elég kicsik és ritkák. Magyarország edényes növényfajainak online adatbázisa mindössze két ponttal jelzi a vizsgált térségében (BARTHA et al. 2021).

Az érintett KEF-kvadrátok listája: 8295.1, 8395.2, 8395.3, 8397.4, 8398.3, 8399.3, 8496.1, 8496.4, 8497.2, 8497.4, 8498.2, 8596.2, 8596.4, 8597.4, 8696.2, 8697.1

\section{Carex stenophylla Wahlenb.}

Lit.: RAPAICS (1916a): Debrecen: Pallag; RAPAICS (1925): Debreceni Nagyerdő; AszóD (1936): Debrecen: Haláp; Soó (1937b): Debrecen: Haláp-Nagycsere pusztai tölgyesekben; PAPP L. (1989): Debrecen: Nagyerdő; NAGY et al. (1990): Bagamér, Daru-hegyek; PAPP et al. (1996/97): Penészlek, Veres-rét; MATUS \& PAPP (2003): Vámospércs: Villongó; Hajdúsámson: Martinkai-legelő; MATUS et al. (2005): Bagamér: Daru-hegyek; TöRöK et al. (2009): Hajdúsámson: Martinkai-legelő; PAPP (2010): Kék-Kálló-völgy pontosabb helymegjelölés nélkül; flóratérképezési adatok ismertek Debrecen, Hajdúbagos, Hajdúhadház, Hajdúsámson, Hajdúböszörmény, Monostorpályi, Létavértes, Penészlek, Újléta területéről (BARTHA et al. 2021).

Ined.: Bagamér: Malom-gát, Csonka-fúz [8597.2] (DL 2017, 2019); Debrecen: Bellegelő (a repülőtértől délre) [8595.2] (DL 2013), Szepes-Őri-dűlő [8595.1] (DL 2014), Szepes [8595.2] és [8595.4] (DL 2014), Dombostanyai-legelő [8396.3] (DL 2017), Halápitározónál [8496.4] (DL 2017); Hajdúbagos: Földikutya Rezervátum [8596.3] (DL 2011, 2017); Hajdúböszörmény: Fekete-dűlő [8295.1] (DL 2017); Hajdúsámson: Martinkailegelő [8496.2] (DL 2013, 2017); Hosszúpályi: Fehértói-tározó töltésén és a bevezető út mentén [8696.3] (DL 2010), Erdőhalmi-dúlő [8696.3] (DL 2014); Létavértes: Nagy-legelő [8597.3] (DL 2017); Mikepércs: Nyárfás-hegyi-legelő [8595.4] (DL 2011, 2017); Monostorpályi: Monostorpályi-legelő [8596.4] (DL 2020); Nyíradony: Penyige-tanya [8397.3] (DL 2020); Nyírábrány: Teleki-legelő [8498.1] (DL 2017); Nyírmártonfalva: Petôrészilegelő [8497.1] (DL 2017); Téglás: Bárány-legelő [8295.4] (DL 2019); Vámospércs: Villongó [8497.4] (DL 2017).

Száraz gyepekben, útszéleken gyakori, Magyarország edényes növényfajainak online adatbázisában azonban van még pótolnivaló a területről (BARTHA et al. 2021).

Az érintett KEF-kvadrátok listája: 8295.1, 8295.4, 8396.3, 8397.3, 8496.2, 8496.4, 8497.1, 8497.4, 8498.1, 8595.1, 8595.2, 8595.4, 8596.3, 8596.4, 8597.2, 8597.3, 8696.3

\section{Carex divisa Huds.}

Lit.: Soó (1948): Debrecen, Nyírség peremi kötött talajon: Tócó-mente, Csónakázótó; MATuS \& PAPP (2001): Bagamér: Daru-hegyek; flóratérképezési adat ismert Debrecen déli határából (BARTHA et al. 2021).

Ined.: Hajdúsámson: Martinkai-legelő [8496.2] (DL 2016); Debrecen: Bellegelő a Balmazújvárosi út déli oldalán, a Tócó és a vasút közötti gyepen [8495.4] (DL 2013).

A nyírségi homokra nem jellemző faj, bár lösszel kevert részein megjelenik. Debreceni adatunk a Hajdúhátra esik. KARÁCSONYI (1995), illetve ADRELEAN \& KARÁCSONYI (2005) több településről leírja a Nyírség romániába eső keleti peremén.

Az érintett KEF-kvadrátok listája: 8495.4, 8496.2 


\section{Carex elata L.}

Lit.: Soó (1932): Haláp; Soó (1934): Debrecen: Tócó-mente, Kondoros, Nagycsere-Martinka, Debrecen-Hajdúsámson; Soó (1937b): Debrecen: Sámsoni úti láp; Penészlek: Peces-tó, Soó (1938): Haláp, valamint Caricetum Hudsonii felvételek Pacról, Bagamérból és Hajdúsámsonból; Soó \& MÁTHÉ (1938) Debrecen: „Tocópart”; Soó (1939): Újléta-Bagamér; SIROKI (1970): Újléta-Létavértes között; NAGY et al. (1990): Bagamér, Daru-hegyek; PAPP et al. (1996/97): Penészlek: Veres-rét; MATuS \& PAPP (2003): Hajdúsámson: Martinkailegelő; PAPP (2003): Vámospércs-Nyíracsád, Jónás rész; PAPP (2010): Kék-Kálló-völgy pontosabb helymegjelölés nélkül; TAKÁcs et al. (2015): Bagamér: Kék-Kálló-völgye; DEMETER (2018): Fülöp: Százholdas, Nyírábrány: Dallárrész, Penészlek: Pócsi-sziget, Vámospércs: Bólya-dűlők; flóratérképezési adatok ismertek Hajdúsámson, Monostorpályi, Nyírmártonfalva, Létavértes, Penészlek, Újléta határából (BARTHA et al. 2021).

Ined.: Álmosd: Kék-Kálló [8597.4] (DL 2016), Daru-láp [8597.2] (SZL DL 2016), Csuszkajó a Bagaméri-ér mentén [8597.4] (DL 2019); Bagamér: Csonka-fűz [8597.2] (DL 2017), Bagaméri-erdő (kis lápfoltban) és Paprét lápján [8497.4] (SZL DL 2014, 2016); Debrecen: Nyárfa-lapos-dűlő [8596.4] (DL 2011, 2013) és [8596.2] (DL 2013), valamint a Nyárfalapos-dűlő délnyugati része, a Pályi-ér mentén [8596.3] (DL 2013), Bánk, a településtől 1 km-re északra, a Bíró-lapostól keletre egy lápos foltban [8596.1] (DL 2011), Szikigyakor (a Sámsoni út menti lápmaradvány) [8496.1] (DL 2011), Nagycsere, a Kőrises Arborétumtól északra és máshol is [8496.4] (DL 2011, 2017), Dombos-tanya, Cserei (B)-csatorna [8396.3] (DL 2017), Halápi-víztározó [8496.4] (DL 2017), a Bodzás-tározótól északkeletre erdőben [8496.4] (DL, 2020), Hosszú-dűlő [8497.1] (DL 2020), Hármas-hegy alja, kaszált állomány is [8496.4] (DL 2018), Haláp, a falutól nyugatra lápfoltban [8496.4] (DL 2020), Bánki-erdő, több helyen [8596.1] (DL 2017) és [8596.2] (DL 2020), Pac, DerecskeiKálló mente [8596.1] (DL 2017), Halápi-erdő [8597.1] (DL 2017), [8497.3] (DL 2019) és [8596.2] (DL, 2020), Fancsika, Kóc-ér mente [8596.1] (DL 2019), Bál-tiszta, a Panoráma út mentén a Fancsika II. tárolótól északra [8496.3] (DL 2020), Fancsika III. tároló [8596.1] (DL 2020); Fülöp: Bivaly-rét [8498.2] (DL 2010), Százholdas, Zöld-Marci-legelő [8498.2] (DL 2013, 2016), Állatorvos-tag, mintegy 600 zsombék [8398.4] (SZL 2015), Nagy-part, 120 zsombék [8398.4] (SZL 2015), Petőfitelep, 25 zsombék [8398.4] (SZL 2015), Fordulódűlő, Rákóczisor mellett [8398.3] (DL 2019); Hajdúbagos: Rókás, 30-40 zsombék [8595.4] (DL 2017); Hajdúhadház: Liget-legelő, több zsombékos a buckaközökben [8396.1] (DL 2015); Hajdúsámson: Martinkai-legelő [8496.2] (DL 2013,2017); Hosszúpályi: Törökmetélő, 10 zsombék pusztuló, kiszáradó hely, valamint Hosszú-gaz [8596.3] (DL 2017); Kokad: Kálló-mente, szórványosan kisebb-nagyobb csoportokban [8597.3, 8597.4] (SZL 2015), Álmosd-Kokadi-tározó [8597.4] (SZL 2016), Nagy-Kaszálón, néhány zsombékos [8597.3] (SZL 2015); Létavértes: Kepecs-tag [8597.3] (SZL 2016), Nagy-legelő, egy zsombékosában 220 zsombék [8597.3] (SZL 2016), Mosonta-rét [8697.1] (DL 2015); Monostorpályi: Monostorpályi-legelő [8596.4] (DL 2021); Nyíracsád: Balkányi-rész [8397.4] (DL 2017), Kis-tag (kubikgödrös) [8397.4] (DL 2017), Jónásrész [8497.2] (DL 2017); Nyíradony: Nagy-Póka lápjaiban [8397.3] (DL 2016), Fényes-tó, északi nádas foltban [8397.2] (DL 2016); Nyírábrány, Kövendi-legelő, egy 1,5 hektáros zsombékos és kisebb állományok a szomszédos lápmedrekben [8497.4] (DL SZL 2009, 2015), Dallárrész [8498.1] (DL SZL 2011, 2015), Teleki-legelő [8498.1] (DL 2014, 2017), Vadon-dűlő [8498.1] (DL 2020); Nyírlugos: Fülöpi-oldal [8398.1] (DL 2016), Szabó-kaszáló, kiterjedt zsombékosok [8398.3] (DL 2020); Nyírmártonfalva: Petőrészi-legelő [8497.1] (DL 2017), Cseres-hegy alatti égerláp [8497.1] (DL 2017), Stern-tag a Bodzás-ér mentén [8497.1] (DL 2017), Juhfürösztő [8497.1] (DL 2017), Büdös-kút (Gúti-erdő) [8397.3] (DL 2020); Penészlek: Peces-tó déli lápja [8499.1] (DL 2017), Veres-rét [8398.4] (DL 2019), Dózer-tó melletti láp [8398.4] (DL 2016); Újléta: Faluszél, a település északnyugati szélén több kisebb 
zsombékos [8597.1] (DL, 2011), Kövesdi-tag, szórványos csoportokban, melyek között 220 zsombékból álló is akad [8597.1] (SZL 2015), Bank-lapos [8597.3] (SZL 2015), Dohányföld (lápok a falu északi oldalán) és Csohos-tó (a Pércsi-ér mentén) [8597.1] (SZL 2016, DL 2019); Vámospércs: Bólya-dúlóben a Monostori-ér menti lápok, az újlétai községhatárnál [8597.1] (DL 2014), Bólya-dúlők északi részén [8597.2] (DL 2020), Villongó [8497.4] (DL 2017), Kőrises-dúlő [8497.4] (DL 2017), Kővágódűlő [8497.3] (DL 2019).

A térségben elterjedt faj. Magyarország edényes növényfajainak online adatbázisában viszont eléggé alulreprezentált (BARTHA et al. 2021). Az utóbbi évek vízhiánya miatt állományai erősen pusztulnak.

Az érintett KEF-kvadrátok listája: 8396.1, 8396.3, 8397.2, 8397.3, 8397.4, 8398.1, 8398.3, 8398.4, 8496.1, 8496.2, 8496.3, 8496.4, 8497.1, 8497.2, 8497.3, 8497.4, 8498.1, 8498.2, 8499.1, 8595.4, 8596.1, 8596.2, 8596.3, 8596.4, 8597.1, 8597.2, 8597.3, 8597.4, 8697.1

\section{Carex acuta L.}

Lit.: MATUS \& PAPP (2001): Bagamér: Daru-hegyek; MATUS \& PAPP (2003): Hajdúsámson: Martinkai-legelő; PAPP (2010): Kék-Kálló-völgy pontosabb helymegjelölés nélkül; TAKÁcS et al. (2016): Bagamér: Kék-Kálló-völgye, Nyírábrány: Mogyorós, Újléta: Kapott-tag; flóratérképezési adatok ismertek Debrecen, Hajdúhadház, Hajdúsámson, Nyírmártonfalva határából (BARTHA et al. 2021).

Ined.: Debrecen: Nyárfa-lapos-dűlő [8596.4] és [8596.2] (DL 2011, 2013, 2017), Haláp-szél (a nyírmártonfalvi határnál) [8497.1] (DL 2010); Létavértes: Falu-rét [8697.1] (DL 2010, 2018); Monostorpályi: Lapos-dűlő [8696.2] (DL 2019); Nyíracsád: Jónásrész [8497.4] (DL 2013).

Előfordulása szórványos, de feltételezzük, hogy a fenti adatoknál kissé elterjedtebb.

Az érintett KEF-kvadrátok listája: 8497.1, 8497.4, 8596.2, 8596.4, 8696.2

\section{Carex cespitosa L.}

Lit.: SIMON (2000): Nyíracsád, Vámospércs; FELFöLDY (2002): Nyírábrány, Nyíracsád, Fülöp; PAPP (2003): Vámospércs-Nyíracsád, Jónásrész; LáJER (2003): Nyírábrány; PAPP (2010): Kék-Kálló-völgy pontosabb helymegjelölés nélkül; DEMETER (2018): Debrecen: Halápierdő, Haláp-szél; Bagamér: Silye-rét; Fülöp: Százholdas; flóratérképezési adat ismert Fülöp határából (BARTHA et al. 2021).

Ined.: Bagamér: Silye-rét északi részén (a Kék-Kálló-völgy északi részén) egy nagyobb foltban kaszálón [8497.4] (DL 2016); Debrecen: Haláp-szél, kisebb állományok több foltban [8497.1] (DL SZL 2011, 2014), Halápi-erdő (a Pércsi-ér mentén, az újlétai községhatár szomszédságában), 1000 zsombék [8597.1] (DL 2013), Halápi-erdő (Erdész-lapos), két foltban 50 és 30 zsombék [8597.1] (DL 2009), Nagy-dúlő, néhány tő molyhos nyírrel vegyes magyar kőrisesben [8496.2] (DL 2014), Bodzás-Fancsika összekötő csatorna mentén 400 tövet meghaladó állomány a kaszáló peremén [8496.4] (Lisztes Anna 2016), Hármashegy-alja, mindössze néhány tő füzláp szegélyén [8496.4] (DL 2017); Fülöp: Marci-legelő lápjaiban két foltban 30 és 100 zsombék [8498.2] (DL SZL 2009), Malom-kert nyírlápjában 30 zsombék [8498.2] (DL 2009), Százholdas két láprétjén szórványos [8498.2] (DL 2014); Kokad: Konyári-Kálló völgye, 3 zsombék [8597.4] (DL 2017); Létavértes: Böcsöntő, 1 zsombék [8597.3] (SZL 2013), Kepecs-tag, kisebb foltokban [8597.3] (SZL 2011), NagyÓcsa, kisebb-nagyobb foltokban [8597.3] (SZL 2010); Monostorpályi: Lapos, $50 \mathrm{~m}^{2}$-es foltban [8696.2] (SZL 2013); Nyíracsád: Jónásrész, lápréti kaszálón [8497.2] (SZL DL 2010, 2016); Nyírábrány: Hanelek, néhány zsombék egy hajdani láprétre telepített nyárasban [8498.2] (DL 2013), Káposztás-lapos, több száz töves állományok [8497.2] (DL 2010), Ludas, a Konyári-Kálló mentén néhány zsombék [8497.4] (SZL 2012), Telekilegelő, szórványos a nyírlápban [8498.1] (DL 2014); Nyírmártonfalva: Lapos-dűlő, több 
lápban kisebb-nagyobb állományok [8497.1] (DL SZL 2011, 2014); Penészlek: Ráta (a Penészleki (VII.)-csatorna mentén), 2 zsombék [8399.3] (SZL 2013), Pócsi-sziget, kaszált gyepben sok [8399.3] (DL SZL 2010), Veres-rét, kevés [8398.4] (SZL, DL 2010, 2017); Újléta: Bank-lapos néhány rétjén kisebb foltokban [8597.1, 8597.3] (SZL DL 2010, 2016), Hegyalja, 1 négyzetméteres foltban [8597.1] (DL 2016), Nagy-Ócsa lápjain foltokban szétszórt állományok [8597.3] (SZL 2010, 2014).

Hazai ritkaságához képest a vizsgált területen jelentős állományai élnek. A Debreceni Egyetem Herbáriumában és a Magyar Természettudományi Múzeum Növénytárában „Carex fusca” és „Carex Goodenowii” felirattal több lap szerepel Halápról és Újlétáról Siroki Zoltán, Soó Rezső és Pénzes Antal gyűjtéséből, melyeket e fajhoz tartozóként azonosítottunk. Hasonló eredményre jutottunk az ELTE Füvészkert herbáriumában Soó Rezső 1934-es halápi és bátorligeti gyüjtésű két „Carex Goodenowii” feliratú lapjával kapcsolatban is. Részletesebben lásd a közlemény végén a Carex nigra tárgyalásánál.

Az érintett KEF-kvadrátok listája: 8398.4, 8399.3, 8496.2, 8496.4, 8497.1, 8497.2, 8497.4, 8498.1, 8498.2, 8597.1, 8597.3, 8696.2

2615. Carex hartmanii Cajander

Lit.: PAPP (2010): Álmosd: Daru-láp északi része, TAKÁcs et al. (2016): Létavértes: Falu-rét.

Herb.: SIROKI Z. (1950. 05. 16.): Haláp (DE) - a Carex Goodenowii Gay. feliratú lapon két Carex hartmanii és egy Carex cespitosa látható; SIROKI Z. (1967. 05. 09.): Újléta (DE) - a Carex nigra (L.) Reincard feliratú lapon egy Carex hartmanii hajtás és két Carex cespitosa példány van.

Ined.: Álmosd: Bihari, 250 virágzó hajtás [8597.4] (SZL 2011); Debrecen: Nagycsere, a Kőrises Arborétum déli oldalán a csatorna mentén 20 négyzetméteren [8496.4] (DL 2017); Létavértes: Falu-rét, 1000 virágzó hajtást meghaladó állomány [8697.1] (SZL 2011, 2012); Monostorpályi: Létai-ér déli oldalán (a településtől délnyugatra) 20 virágzó hajtás [8696.2] (Lovas-Kiss Ádám 2012); Nyírmártonfalva: Lapos-dűlő, több ezer virágzó hajtás egy kaszált lápréten $C$. cespitosa és $C$. appropinquata társaságában [8497.1] (DL, SZL 2011); Újléta: Hegyalja, 15 virágzó hajtás [8597.1] (SZL 2010); Vámospércs: Gyula-tag, 14 virágzó hajtás [8597.2] (SZL 2014), Kőrises-dűlő (Jónásrész), a zergeboglárok közelében néhány négyzetméteren [8497.2] (DL 2017).

Meglepetést okozott az északi sás állományainak egymást követő megtalálása 2010-től. Az első észlelésünket követően PAPP (2010) szintén megtalálta Álmosdon egy másik helyen, majd a Létavértesen talált állományt TAKÁcs et al. (2016) is közli. Ezek újnak számítottak az Eupannonicum flóravidékének hazai részére. A Nyírség romániai részén viszont már ismert faj. KARÁCSONYI (1995) ugyanis korábban már közölte Ligettanya (Scărişoara Nouă) határából. A fekete sás (Carex nigra (L.) Reichard) adatai után kutatva a Debreceni Egyetem Siroki Zoltán Herbáriumának fentebb leírt két lapján is megtaláltuk ezt a növényt. A Siroki által megadott újlétai gyűjtőhely közelében található az általunk fellelt első termőhely, Halápról viszont nem ismerünk recens adatot. Alkalmunk volt megfigyelni érdekes morfológiai eltéréseket a terméses hajtásokon egymást követő években, ugyanazon állományban. A szárazabb éveket követő erősen belvizes 2010-es évben Újlétán talált első növényeken a termős füzérkék erősen összetorlódva, egymáshoz közel helyezkedtek el. A termős pelyvák meglehetősen világosak voltak, és a csúcsi füzérke is nagyrészt termős virágokból állt. 2011-ben ugyanebben az állományban a jól ismert sötét termős pelyvájú, megnyúlt virágzatok fejlődtek. A csúcsi füzérke pedig sok porzós virágot tartalmazott, vagy gyakran tisztán porzós virágokból állt.

Az érintett KEF-kvadrátok listája: 8496.4, 8497.1, 8497.2, 8597.1, 8597.2, 8597.4, 8696.2, 8697.1 
2616. Carex buxbaumii Wahlenb.

Lit.: DEMETER \& SzÉL (2014): Vámospércs.

Ined.: Vámospércs, Kőrises-dủlő (Jónásrész) tisztásán mintegy 240 virágzó hajtás [8497.4]

(SZL DL, 2010). Megegyezik az irodalmi említéssel, de korábban találtuk.

Legnagyobb meglepetést e sásfaj megtalálása okozta, amit az tett lehetővé, hogy az élőhelyéül szolgáló becserjésedett tisztáson cserjeirtást végeztünk az ott élő orchideák és más védett növények érdekében. A növényt ezután sokan megnézték, és már egy pont jelzi is a Magyarország edényes növényfajainak elterjedési atlaszában, ismeretterjesztő cikkünk nyomán. $\mathrm{Az}$ ott szereplő KEF kvadrát viszont hibás! A helyes kvadrátot itt közöljük. A faj újnak számít nemcsak a Nyirségense flórajárására, de az egész Eupannonicum flóravidékére is.

Az érintett KEF-kvadrát: 8497.4

2618. Carex hirta L.

Lit.: RAPAICS (1916a): Debrecen: Pallagon és Nagyerdőben; RAPAICS (1925): Debreceni Nagyerdő; SIRoKI (1970): Újléta-Létavértes között; NAGY et al. (1990): Bagamér, Daru-hegyek; PAPP et al. (1996/97): Penészlek, Veres-rét; MATUS \& PAPP (2003): Vámospércs: Villongó, Hajdúsámson: Martinkai-legelő; MATus et al. (2005): Bagamér, Daru-hegyek; a flóratérképezési adatok szerint a vizsgált területen általánosan elterjedt (BARTHA et al. 2021).

Ined.: Álmosd: Daru-láp [8597.2] (DL 2009); Bagamér: Malom-gát [8597.2] (DL 2017); Debrecen: Nyárfa-lapos-dúlő [8596.4] (DL 2011, 2013) és [8596.2] (DL 2013), Bodzástározótól keletre eső gyepen [8496.4] (DL 2013), Sámsoni úti Bellegelő [8496.1] (DL 2017), Erős-lyuk kaszálója [8496.2] (DL 2017), Fancsika II. tárolótól északkeletre tölgyes [8496.3] (DL 2018), Nagycserei Kőrises Arborétum déli oldalán [8496.4] (DL, 2017), Bodzás-tározó melletti rétek, tározótöltések [8496.4] (DL 2017, 2018), Hosszú-dúlő [8497.1] (DL, 2019), Paci-erdő [8596.1] (DL, 2019), Nyárfa-lapos-dűlő [8596.2] (DL 2017), Bánki-erdő [8596.2] (DL 2017, 2018), Halápi-erdő [8596.2] (DL 2018), Halápierdő (nyíres tölgyes) [8597.1] (DL 2017); Fülöp, Százholdas [8498.2] (DL 2013), Windicsrész [8498.1] (DL 2017); Hajdúbagos: Földikutya Rezervátum [8596.3] (DL 2011); Hajdúsámson: Martinkai-legelő [8496.2] (DL 2013, 2017); Létavértes: Nagy-legelő [8597.3] (DL 2017); Mikepércs: Nyárfás-hegyi-legelő [8595.4] (DL 2011); Monostorpályi: Bónis-hegy a Rapi-tanya mellett [8596.4] (DL 2017), Monostorpályi-legelő [8596.4] (DL 2017); Nyíracsád: Balkányi-rész [8397.4] (DL 2017), Kis-tag (kubikgödrös) [8397.4] (DL 2017), Jónásrész [8497.2] (DL 2017); Nyíradony: Gúti-erdő [8397.2] (DL 2019); Nyírábrány: Káposztás-lapos [8497.2] (DL 2017); Nyírmártonfalva: Ártánházi-szántó [8397.4] (DL 2017), Petőrészi-legelő [8497.1] (DL 2017); Penészlek: Veres-rét [8398.4] (DL 2017); Újléta: Fövenyes [8597.3] (DL 2018); Vámospércs: Kőrises-dúlő [8497.2] (DL 2017), Villongó [8497.4] (DL 2017), Bólya-dűlő [8597.2] (DL 2017).

Gyakorisága miatt adatainak gyüjtése nem volt kifejezett célunk. Az itt felsoroltak mindössze 2 alnégyzetet tesznek hozzá újként Magyarország edényes növényfajainak online adatbázisához.

Az érintett KEF-kvadrátok listája: 8397.2, 8397.4, 8398.4, 8496.1, 8496.2, 8496.3, 8496.4, 8497.1, 8497.2, 8497.4, 8498.1, 8498.2, 8595.4, 8596.1, 8596.2, 8596.3, 8596.4, 8597.1, 8597.2, 8597.3

\section{Carex flacca Schreb.}

Lit.: RAPAICS (1916a): Debrecen: Pallag; Soó (1934): Debrecen: Haláp, Csere-erdő; Penészlek: Peces-tó; SIROKI (1970): Újléta-Létavértes között; MATUS \& PAPP (2003): Vámospércs: Villongó; Hajdúsámson: Martinkai-legelő; flóratérképezési adatok ismertek Debrecen, Fülöp, Hajdúsámson, Monostorpályi, Létavértes, Penészlek, Újléta határából (BARTHA et al. 2021).

Ined.: Bagamér: Nagy-erdő [8597.2] (DL 2020); Debrecen: Nyárfa-lapos-dúlő [8596.4] (DL 
2011, 2013), a Halápi-tározótól délre tölgyesben [8596.2] (DL 2019), Bodzás-tározótól keletre eső gyepen [8496.4] (DL 2013), Erős-lyuk kaszálón és a Nagy-tagban tölgyesben [8496.2] (DL 2017, 2021), Cserei-dűlő [8496.3] (DL 2018), Nagycsere [8496.4] (DL, 2017), Hármas-hegy alja [8496.4] (DL, 2018), Bodzás-tározótól keletre levő kaszáló és északkeletre erdőben [8496.4] (DL, 2018, 2020), Halápi-erdő (Álló-hegy melletti rét) [8497.3] (DL 2017), Hosszú-dűlő [8497.1] (DL 2019), Halápi-erdő (nyíres tölgyes) és fiatalabb tölgyesekben is [8597.1] (DL 2017, 2020), Bánki-erdő, Halápi-erdő [8596.2] (DL, 2020); Hajdúsámson: Martinkai-legelő [8496.2] (DL 2013); Létavértes: Falu-rét [8697.1] (DL 2010); Monostorpályi: Bónis-hegy, Rapi-tanya mellett [8596.4] (DL 2017) a hosszúpályi út mentén a községhatáron levő régi kubikban: [8696.2] (DL 2011), Monostorpályilegelő [8596.4] (DL 2020); Nyíracsád: Kis-tag (kubikgödrös) [8397.4] (DL 2017), Jónásrész [8497.2] (DL 2017); Nyírmártonfalva: Petôrészi-legelő [8497.1] (DL 2017), Büdöskút (Gúti-erdő) [8397.3] (DL 2020), Berek-szilas a gúti ér mentén [8397.4] (DL 2021); Nyírábrány: Káposztás-lapos [8497.2] (DL 2017), Teleki-legelő és Mogyorós-erdő [8498.1] (DL 2017, 2020); Penészlek: Veres-rét [8498.2] (DL 2017); Újléta: Kis-erdő [8597.3] (DL 2021); Vámospércs: Kőrises-dűlő [8497.2] (DL 2017).

A vizsgált területen elterjedt faj erdőkben és réteken egyaránt.

Az érintett KEF-kvadrátok listája: 8397.3, 8397.4, 8496.2, 8496.3, 8496.4, 8497.1, 8497.2, 8497.3, 8498.1, 8498.2, 8596.2, 8596.4, 8597.1, 8597.2, 8597.3, 8696.2, 8697.1

\section{Carex humilis Leyss.}

Lit.: flóratérképezési adata ismert Bagamér határából (BARTHA et al. 2021).

Ined.: Bagamér: Malom-gáton kevés [8597.2] (DL, 2017).

Az egész Nyírségben ritka, a fentin kívül csak Bátorligetről (Soó 1973) és Nyírpilisről (Lesku Balázs 2003 flóratérképezési adat) ismert. Mi is csak a korábbi adatát tudjuk megerősíteni a vizsgált területen.

Az érintett KEF-kvadrát: 8597.2.

\section{Carex umbrosa Host.}

Lit.: PAPP (2010): Bagamér: Kék-Kálló-völgy a bagaméri úttól északra.

Ined.: Bagamér: Silye-rét, minimum 60 tő [8497.4] (SZL 2010); Fülöp: Nagy-part, 1 tő kékperje között [8398.4] (DL 2015); Nyírábrány: Káposztás-lapos néhány tő [8497.2] (DL 2010); Újléta: Bank-lapos, 7 tő [8597.1] (SZL 2010, 2012).

A Nyírségbőll egyetlen irodalmi említése volt ismert Bátorligetről (STANDovár et al. in MAHUNKA 1991). PAPP (2010) már az általunk megtalált egyik állományt jelzi ismeretterjesztő kiadványában. Feltúnő volt, hogy minden termőhelyén előfordult a fehér zászpa (Veratrum album L.) is. Fülöpön 2020-ban már nem sikerült újra fellelni. Az utóbbi száraz években a Káposztás-laposon nem virágzott.

Az érintett KEF-kvadrátok listája: 8398.4, 8497.2, 8497.4, 8597.1

\section{Carex caryophyllea Latourr.}

Lit.: RAPAICS (1916a): Debrecen: Pallagon és Halápon; Soó (1937a): Debreceni Nagyerdő; Soó (1937b): Debrecen: Haláp-Nagycsere pusztai tölgyesekben; PAPP L. (1989): Debrecen: Nagyerdő; NAGY et al. (1990): Bagamér, Daru-hegyek; TAKÁCS et al. (2016): Monostorpályi: a falutól ÉK-re elterülő gyepek; flóratérképezési adatok ismertek Penészlek, Vámospércs határából (BARTHA et al. 2021).

Ined.: Bagamér: Malom-gát foltokban [8597.2] (DL 2017); Debrecen: Álló-hegy [8497.3] (DL 2010-2016), Bánki-erdő, néhány foltban [8596.2] (DL 2017), Hosszú-dűlő [8497.1] (DL 2021), Kalánhegyi-tölgyes, szórványos [8596.2] (DL 2017), Nagycsere (a 48-as út 
északi oldalán Haláp előtt) [8496.4] (DL 2019), Nagy-tag [8496.2] (DL 2021), Paci-erdő [8596.1] (DL 2019); Hajdúbagos: Földikutya Rezervátum, nagy foltokban [8596.3] (DL 2011), Hosszúpályi: Erdőhalmi-dúlő [8696.3] (DL 2014); Létavértes: Nagy-legelő, szórványos [8597.3] (DL 2017); Monostorpályi: Monostorpályi-legelő a Kis-Pályi-ér mentén [8596.4] (DL 2019); Nyíracsád: Jónásrész [8497.4] (DL 2017); Nyírmártonfalva: Petőrészi-legelő [8497.1] (DL 2017); Vámospércs: Jónásrész [8497.4] (DL 2017), Bólya-dúlő [8597.2] (DL, 2017).

A térségében szórványos előfordulású homoki tölgyesekben és homoki legelők mezofilabb részein.

Az érintett KEF-kvadrátok listája: 8496.4, 8497.1, 8497.3, 8497.4, 8596.1, 8596.2, 8596.3, 8596.4, 8597.2, 8597.3, 8696.3

\section{Carex tomentosa $\mathrm{L}$.}

Lit.: RAPAICS (1916a): Pallagon és Halápon; RAPAICS (1925): Debreceni Nagyerdő; Soó (1934): Peces-tó; Matus \& PAPP (2003): Vámospércs: Villongó; Hajdúsámson: Martinkailegelő; TAKÁCs et al. (2016): Létavértes: Falu-rét, Monostorpályi: Damjanich utca vége; flóratérképezési adat ismert még Penészlek határából (BARTHA et al. 2021).

Ined.: Álmosd: Daru-láp [8597.2] (DL 2009); Debrecen: Nyárfa-lapos-dúlő [8596.4] (DL 2011, 2013), Tócó-völgy [8395.3] (DL 2017), Halápi-erdő („nyíres tölgyes”) [8597.1] (DL 2017), Cserei-dűlő [8496.3] (DL 2020); Hajdúbagos: Sárándi-Külső-határ [8695.2] (DL 2020); Hajdúböszörmény: Nagy-Nyerges [8295.1] (DL 2017); Hajdúsámson: Martinkailegelő [8496.2] (DL 2013); Monostorpályi: Leány-tó és a Konyári-Kálló között [8696.2] (DL 2019); Nyíracsád: Kis-tag (kubikgödrös) [8397.4] (DL 2017); Nyírábrány: Hanelek [8498.2] (DL 2020), Mogyorós-erdő és Teleki-legelő [8498.1] (DL 2020); Újléta: Banklapos [8597.1] (DL, SZL 2011) Vámospércs: Kőrises-dűlő [8497.2] (DL 2017).

Elterjedése szórványos a térségben, Magyarország edényes növényfajainak online adatbázisában viszont alig jelzi innen (BARTHA et al. 2021).

Az érintett KEF-kvadrátok listája: 8295.1, 8395.3, 8397.4, 8496.2, 8496.3, 8497.2, 8498.1, 8498.2, 8596.4, 8597.1, 8597.2, 8695.2, 8696.2,

\section{Carex pseudocyperus L.}

Lit.: Soó (1932): Debrecen: Haláp, zsombékosokban; Soó (1934): Debrecen: Haláp; Soó (1937b): Penészlek: Peces-tó; Soó (1938): Debrecen: Haláp (cönológiai felvételben); Soó (1939): Újléta-Bagamér; SIROKI (1970): Debrecen: Sámsoni úti láp; PAPP et al. (1996/97): Penészlek, Veres-rét; PAPP (2010): Létavértes: égerláp; TAKÁcs et al. (2016): Nyírábrány: Keszler-tag, Újléta: Új-Ócsa; MATUS et al. (2019): Kokad, Daru-láp; flóratérképezési adat ismert még Penészlek határából (BARTHA et al. 2021).

Ined.: Álmosd: Daru-láp [8597.2] (DL 2009); Debrecen: a Sámsoni út menti lápmaradvány [8496.1] (DL 2011), Halápi-tározó északi végénél füzlápban és Haláp mellett a 48-as út árkában [8496.4] (DL 2015, 2019), Nyárfa-lapos-dűlő [8596.2] (DL 2017), Hosszúdűlőben lápra ültetett égeresben [8497.1] (DL 2021), Nagycserén rekettyés füzlápban a Kőrises Arborétumtól északra [8496.4] (DL 2021); Fülöp: Windics-rész [8398.3] (DL 2015), Zöld-Marci-legelő [8498.2] (DL 2016); Kokad: Daru-láp [8597.4] (DL 2018); Létavértes: Mosonta-rét [8697.1] (DL 2014), Toszorka-rét (Kossuth-kert mellett) égerlápjában szórványos [8597.3] (DL 2017), Görög-rét, nagy állomány a tározóban [8597.3] (SZL 2015); Nyírmártonfalva: Lapos-dúlő egyik füzlápjában [8497.1] (DL 2011); Nyíracsád: Rikács, füzlápban [8398.3] (DL 2011, 2015); Nyíradony: Tivorány (Harmadik-forduló) égerlápjában [8397.2] (DL 2017); Penészlek: Veres-rét, szórványos a füzlápban [8398.4] (DL 2017); Újléta: Kövecses-tag [8597.1] (DL 2014), Faluszél, a település északnyugati szélén rekettyés füzlápban [8597.1] (DL 2011); Vámospércs: Bólya-dűlő, a Monostori-ér menti lápok, az újlétai községhatárnál [8597.1] (DL 2014). 
Szórványos előfordulású a térség égerlápjaiban és füzlápjaiban.

Az érintett KEF-kvadrátok listája: 8397.2, 8398.3, 8398.4, 8496.1, 8496.4, 8497.1, 8498.2, 8596.2, 8597.1, 8597.2, 8597.3, 8597.4, 8697.1

\section{Carex sylvatica Huds.}

Lit.: RAPAICS (1916a): Debreceni Nagyerdő; RAPAICS (1925): Debreceni Nagyerdő; Soó (1932): Haláp; Soó (1934): Debrecen: Haláp, Paci-erdő; AszóD (1936): Debrecen: Nagyerdő; Soó R. (1937b): Debrecen: Nagyerdő, Haláp-Nagycsere keményfás ligeterdőben; BARTHA D. (1988): Hajdúböszörmény: Városerdő; PAPP L. (1989): Debrecen: Nagyerdő; KEVEY et al. (2017a) cönológiai felvételekben: Debrecen: Nagyerdő, Nagycsere, Halápi-erdő, Nyírábrány: „Kiskőrises”; KevEY et al. (2017b) cönológiai felvételekben: Debrecen: Nagyerdő; flóratérképezési adatok ismertek Debrecen, Bocskaikert, Hajdúhadház határából (BARTHA et al. 2021).

Ined.: Bagamér: Nagy-erdő [8597.2] (DL 2018); Bocskaikert: Nagy-erdő [8396.3] (DL 2020); Debrecen: Nagyerdő és Apafai-erdő [8495.2] (DL 2010, 2019), Nagycserei Kőrises Arborétum [8496.4] (DL 2010-2020), Haláp falu mellett és tőle északra keményfás ligeterdőben [8496.4] (DL 2013), Nyárfa-lapos-dúlő [8596.2] (DL 2013), Monostori-erdő [8395.4] (DL 2017) és [8495.2] (DL 2017), Hármas-hegy-alja [8496.4] (DL 2017), Halápierdő [8597.1] (DL 2017), Szentgyörgyi-erdő [8395.4] (DL 2020); Nyíracsád: Külső-Gút [8397.2] (DL 2012); Nyíradony: Harmadik-forduló (a Gúti-ér közelében) [8397.2] (DL 2012); Nyírábrány: Mogyorós-erdő [8498.1] (DL 2017); Téglás: Angolkert [8295.4] (DL 2010).

A térség régi erdőtömbjeiben szórványos.

Az érintett KEF-kvadrátok listája: 8295.4, 8395.4, 8396.3, 8397.2, 8495.2, 8496.4, 8498.1, 8596.2, 8597.1, 8597.2

\section{Carex pallescens $\mathrm{L}$.}

Lit.: Soó (1934): Debrecen: Pac-erdő; Hajdúbagosi-erdő; Soó (1937b): Debreceni Nagyerdő, PAPP (2010): Álmosd: Daru-láp.

Ined.: Álmosd: Daru-láp kis kaszálóján 20 tő [8597.2] (DL 2009, 2018); Bagamér: Nagyerdő [8597.2] (DL 2020); Debrecen: Erős-lyuk [8496.2] (DL 2017), Nagy-tag több tölgyesében (Hármashegyi-tölgyesek) [8496.2] (DL 2018), Nagycsere (sámsoni földút menti tölgyesek) [8496.4] (DL 2020), Rauchbauer-erdő [8497.1] (DL 2018), Álló-hegy [8497.3] (DL 2018), Halápi-erdő egy „nyíres tölgyesében” és Haláp-szél [8597.1] (DL 2017, 2018), a Bál-hegy északi oldalán [8496.3] (DL 2020), Bánki-erdő és Halápi-erdő [8596.2] (DL 2020); Hajdúbagos: Sűrü tisztája [8596.3] (DL 2018); Hajdúhadház: Nagy-erdő [8396.1] (DL 2020), Csereerdő [8395.2] (DL 2021); Hajdúsámson: Martinkai-legelő (délkeleten a tölgyes mellett); Monostorpályi: Csík-gát egy fiatal tölgyesében szórványos és a Kis-Pályiér mentén kékperjésben [8596.4] (DL 2018, 2019); Nyíracsád: Jónásrész (sok egy fiatalabb tölgyesben) [8497.4] (DL 2018).

A vizsgált térségében apró állományai szórványos előfordulásúak tölgyesekben és kékperjés réteken. Magyarország edényes növényfajainak online adatbázisa (BARTHA et al. 2021) nem jelzi innen.

Az érintett KEF-kvadrátok listája: 8395.2, 8396.1, 8496.2, 8496.3, 8496.4, 8497.1, 8497.3, 8497.4, 8596.2, 8596.3, 8596.4, 8597.1, 8597.2

2637. Carex supina Wahlenb.

Lit.: Soó (1932): Debrecen: Haláp; AszóD (1936): Debrecen: Haláp; Soó (1937b): Debrecen: Haláp-Nagycsere pusztai tölgyesekben; PAPP L. (1989): Debrecen: Nagyerdő; NAGY et al. (1990): Bagamér, Daru-hegyek; MATUS \& PAPP (2003): Hajdúsámson: Martinkai-legelő; 
MATUS et al. (2005): Bagamér: Daru-hegyek; MATus et al. (2019): Bagamér, Daru-hegyek (Malom-gát), Álmosd; flóratérképezési adat ismert Penészlek határából (BARTHA et al. 2021).

Ined.: Bagamér: Malomgát [8597.2] (DL 2017); Debrecen: Álló-hegy [8497.3] (DL 20102016), Sámsoni úti Bellegelő [8496.1] (DL 2017); Hajdúbagos: Földikutya Rezervátum [8596.3] (DL 2017); Hajdúhadház: Liget-legelő [8396.1] (DL 2015, 2017); Létavértes: Nagy-legelő [8597.3] (DL 2017) és [8597.4] (DL 2017); Mikepércs: Nyárfás-hegyi-legelő [8595.4] (DL 2011) és [8596.3] (DL 2017); Monostorpályi: Monostorpályi-legelő keleti részén [8596.4] (DL 2010); Nyírlugos: Szabó-kaszáló [8398.3] (DL 2019); Nyírmártonfalva: Petőrészi-legelő [8497.1] (DL 2017); Vámospércs: Bólya-dűlő (nagyezerjófüves domboldalon és a bagaméri ezüshársas tölgyes mellett) [8597.2] (DL 2019, 2020).

Szórványos előfordulását észleltük a nagyobb homoki legelőkön és helyenként homoki tölgyesek tisztás részein.

Az érintett KEF-kvadrátok listája: 8396.1, 8398.3, 8496.1, 8497.1, 8497.3, 8595.4, 8596.3, 8596.4, 8597.2, 8597.3, 8597.4

2638. Carex acutiformis Ehrh.

Lit.: Soó (1934): a Nyírségben közönséges; Soó (1937b): Debrecen: Haláp-Nagycsere keményfás ligeterdőben, Sámsoni úti láp; Penészlek: Peces-tó; Hosszúpályi mellett; Soó (1938): Debrecen: Haláp (cönológiai felvételben); SIROKI (1970): Újléta-Létavértes között; PAPP et al. (1996/97): Penészlek, Veres-rét; MATUS \& PAPP (2003): Vámospércs: Villongó; Hajdúsámson: Martinkai-legelő; LÁjER (2003): Nyírábrány; TöRöK et al. (2009): Hajdúsámson: Martinkai-legelő (magkészletben kimutatva); PAPP (2010): Kék-Kálló-völgy pontosabb helymegjelölés nélkül; KEVEY et al. (2017a) cönológiai felvételekben: Nyírábrány: „Kiskőrises” és Mogyorós-erdő; flóratérképezési adatok szerint a vizsgált területen általánosan elterjedt (BARTHA et al. 2021).

Ined.: Álmosd: Daru-láp [8597.2] (DL 2009, 2017), Csuszkajó [8597.4] (DL 2019); Bagamér: Malom-gát [8597.2] (DL 2017); Debrecen: Nyárfa-lapos-dúlő [8596.4] (DL 2011) és [8596.2] (DL 2017), Szikigyakor (a Sámsoni út menti lápmaradvány) [8496.1] (DL 2011), Szepes vasúti megállótól kissé nyugatra [8595.2] (DL 2012), Nagycsere [8496.4] (DL 2017), Halápi-víztározó [8496.4] (DL 2017), Nagycsere, Kőrises Arborétum déli oldalán és a Derecskei-Kálló nyugati oldalán [8496.4] (DL 2017, 2018), Hármas-hegy-alja [8496.4] (DL 2017) és [8497.3] (DL, 2018), Bodzás-tározótól keletre levő kaszáló [8496.4] (DL 2018), Pac: Derecskei-Kálló medre [8596.1] (DL 2017), Bánki-erdő [8596.2] (DL 2018), Halápi-erdő [8597.1] (DL 2017) és [8497.3] (DL 2019); Fülöp: Százholdas [8498.2] (DL 2013), Forduló-dúlő (Rákóczisor mellett) [8398.3] (DL 2019); Hajdúsámson: Martinkai-legelő [8496.2] (DL 2013, 2017); Hajdúbagos: Rókás [8595.4] (DL 2017); Létavértes: Falu-rét [8697.1] (DL 2010), Nagy-legelő [8597.3] (DL 2017), Toszorka-rét (Kossuth-kert melletti égerláp) [8597.3] (DL 2017), Böcsöntő (zsilip környékén) 0 [8597.3] (DL 2017); Mikepércs: Nyárfás-hegyi-legelő [8595.4] (DL 2011); Monostorpályi: Bónis-hegy (Rapi-tanya mellett) [8596.4] (DL 2017); Nyírmártonfalva: Ártánháziszántó [8397.4] (DL 2017); Nyíracsád: Balkányi-rész és Kis-tag (kubikgödrös) [8397.4] (DL 2017), Jónásrész [8497.2] (DL 2017) és [8497.4] (DL 2017); Nyíradony: Fényes-tó (északi nádas foltban) [8397.2] (DL 2019); Nyírábrány: Teleki-legelő [8498.1] (DL 2017), Keszler-tag [8498.1] (DL 2017); Nyírlugos: Szabó-kaszáló [8398.3] (DL 2020); Nyírmártonfalva: Petőrészi-legelő [8497.1] (DL 2017), Stern-tag a Bodzás-ér mentén [8497.1] (DL 2017); Penészlek: Veres-rét [8498.2] (DL 2017); Téglás: Angolkert [8395.2] (DL 2019); Vámospércs: Kőrises-dűlő [8497.2] (DL 2017), Bólya-dűlő a Monostori-ér menti lápok az újlétai községhatárnál [8597.1] (DL 2014).

Az érintett KEF-kvadrátok listája: 8395.2, 8397.2, 8397.4, 8398.3, 8496.1, 8496.2, 8496.4, 8497.1, 
DEMETER \& SzÉL (2021): Adatok a sásfajok előfordulásához a Dél-Nyírségben és környékén

8497.2, 8497.3, 8497.4, 8498.1, 8498.2, 8595.2, 8595.4, 8596.1, 8596.2, 8596.4, 8597.1, 8597.2, 8597.3, 8597.4, 8697.1

\section{Carex riparia Curtis}

Lit.: Soó (1932): Debrecen: Haláp; Soó (1934): a Nyírségben közönséges, Debrecen: Tócómente; Vámospércs; Hajdúsámson-Hajdúhadház; Soó (1937a): Hajdúbagos; Debrecen: Haláp; Soó (1937b): Debrecen: Haláp; Soó (1938): Debrecen: Haláp (cönológiai felvételben); Soó \& MÁTHÉ (1938) Debrecen: "Tocómente"; Soó (1939): Újléta-Bagamér; SIROKI (1970): Újléta-Létavértes között; PAPP et al. (1996/97): Penészlek, Veres-rét; MATUS \& PAPP (2003): Vámospércs: Villongó; Hajdúsámson: Martinkai-legelő; PAPP (2010): KékKálló-völgy pontosabb helymegjelölés nélkül; KEVEY et al. (2017a) cönológiai felvételekben: Nyírábrány: „Kiskőrises” és Mogyorós-erdő; flóratérképezési adatok ismertek Debrecen, Hajdúhadház, Fülöp, Penészlek, Vámospércs határából (BARTHA et al. 2021).

Ined.: Álmosd: Csuszkajó a Bagaméri-ér mentén [8597.4] (DL 2019); Debrecen: Nyárfalapos-dűlő [8596.4] (DL 2011, 2013) és [8596.2] (DL 2013), Szepes-Őri-dűlő [8595.1] (DL 2014), Dombostanyai-legelő [8396.3] (DL 2017), Sámsoni úti Bellegelő a „tankúsztatóban" [8496.1] (DL 2017), Panoráma út mentén a Fancsika II. tárolótól északra [8496.3] (DL 2020), Halápi-víztározó [8496.4] (DL 2017), Nagycsere [8496.4] (DL 2017), Hármashegy alja [8496.4] (DL 2018), Halápi-erdő [8497.3] (DL 2019), Bánki-erdő [8596.1] (DL 2017), Pac, (Derecskei-Kálló mente) [8596.1] (DL 2017), Nyárfa-lapos-dűlő [8596.2] (DL 2017), Mézeshegyi-tározó [8596.3] (DL 2019), Nyárfa-lapos-dűlő (ATEV tó) [8596.4] (DL 2017); Fülöp: Százholdas [8498.2] (DL 2013), Forduló-dűlő (Rákóczisor mellett) [8398.3] (DL 2019); Hajdúbagos: Földikutya Rezervátum [8596.3] (DL 2011), Rókás (Földikutya Rezervátumban) [8595.4] (DL 2017); Hajdúböszörmény: Nagy-Nyerges [8295.1] (DL 2017); Hajdúsámson: Martinkai-legelő [8496.2] (DL 2013); Hosszúpályi: Hosszú-gaz [8596.3] (DL 2021); Nyíradony: Fényes-tó (északi nádas folt) [8397.2] (DL 2019); Nyírábrány: Keszler-tag [8498.1] (DL 2017); Nyírlugos: Szabó-kaszáló [8398.3] (DL 2020); Nyírmártonfalva: Ártánházi-szántó [8397.4] (DL 2017), Petőrészi-legelő [8497.1] (DL 2017), Stern-tag a Bodzás-ér mentén [8497.1] (DL 2017); Penészlek: Veres-rét [8498.2] (DL 2017); Téglás: Lápos-rét [8395.2] (DL 2019); Újléta: Csohos-tó (a Pércsi-ér mentén) [8597.1] (DL 2019); Vámospércs: Kőrises-dűlő [8497.2] (DL 2017), Villongó [8497.4] (DL 2017).

Általános elterjedtsége ellenére Magyarország edényes növényfajainak online adatbázisa igen kevés adatot közöl innen a közlemény készítése idején (BARTHA et al. 2021).

Az érintett KEF-kvadrátok listája: 8295.1, 8395.2, 8396.3, 8397.2, 8397.4, 8398.3, 8496.1, 8496.2, 8496.3, 8496.4, 8497.1, 8497.2, 8497.3, 8497.4, 8498.1, 8498.2, 8595.1, 8595.4, 8596.1, 8596.2, 8596.3, 8596.4, 8597.1, 8597.4

\section{Carex vesicaria L.}

Lit.: Soó (1934): Debrecen: Haláp; Soó (1937a): Debrecen: Haláp; SIROKI (1965): Debrecen; SIROKI (1970): Újléta-Létavértes között; Debrecen: Sámsoni úti láp; NAGY et al. (1990): Bagamér, Daru-hegyek; PAPP et al. (1996/97): Penészlek, Veres-rét; MATUS \& PAPP (2003): Hajdúsámson: Martinkai-legelő; PAPP (2010): Kék-Kálló-völgy pontosabb helymegjelölés nélkül; flóratérképezési adat ismert Penészlek határából (BARTHA et al. 2021).

Ined.: Álmosd: Daru-láp [8597.2] (DL 2009, 2017); Bagamér: Malom-gát [8597.2] (DL 2017); Fülöp: Százholdas [8498.2] (DL 2013); Kokad: Konyári-Kálló völgye [8597.4] (DL 2014); Létavértes: Nagy-legelő C. elata zsombékosban és máshol is [8597.3] (DL 2017) és [8597.4] (DL 2018); Nyírábrány: Teleki-legelő [8498.1] (DL 2017); Penészlek: Kerek-nád [8399.3] (DL 2012), Bergel-tag [8398.4] (DL 2017), Veres-rét [8498.2] (DL 2017).

Ez a sás viszonylag ritkának számít a vizsgált területen.

Az érintett KEF-kvadrátok listája: 8398.4, 8498.1, 8498.2, 8597.2, 8597.3, 8597.4 
2642. Carex melanostachya Willd.

Lit.: Soó (1932): Hajdúsámson (Carex nutans néven); Soó (1934): Hajdúsámsoni adata törlendő; Soó (1939): Hajdúbagos; flóratérképezési adat ismert Debrecen, Létavértes határából (BARTHA et al. 2021).

Ined.: Debrecen: Nyárfa-lapos-dűlő [8596.4] (DL 2011), Szepes [8595.2] (DL 2014), Bellegelő, a reptértől délre levő gyep déli végén [8595.2] (DL 2012), Bál-hegytől északra [8496.3] (DL 2020); Hajdúbagos: Földikutya Rezervátum [8596.3] (DL 2011); Hajdúböszörmény: Fekete-dűlő [8295.1] (DL 2017), Nagy-Nyerges (szikes ér) [8295.1] (DL 2017); Hajdúsámson: Martinkai-legelő [8496.2] (DL 2013); Hosszúpályi: Fehértói-tározó északi végénél [8696.3] (DL 2011), Szomjú-hát-dűlő [8696.1] (DL 2015); Mikepércs: Nyárfáshegyi-legelö [8595.4] (DL 2011).

Ez a faj nem jellemző igazán a homokvidékre. Adataink többsége szomszédos kistájra, vagy talajtani szempontból átmeneti zónába esik.

Az érintett KEF-kvadrátok listája: 8295.1, 8496.2, 8496.3, 8595.2, 8595.4, 8596.3, 8596.4, 8696.1, 8696.3, 8696.4

\section{Carex panicea L.}

Lit.: Soó (1932): Haláp; Soó (1934): Debrecen: Haláp, Debrecen-Hajdúsámson, Hajdúsámson, Vámospércs, Penészlek: Pecestó; Soó (1937a): Debrecen: Pallag; Soó (1937b): Debrecen: Haláp; Penészlek: Peces-tó, Soó (1938): Haláp (cönológiai felvételben); Soó (1939): Újléta-Bagamér; PAPP et al. (1996/97): Penészlek: Veres-rét; MATuS \& PAPP (2003): Hajdúsámson: Martinkai-legelő; PAPP (2010): Kék-Kálló-völgy pontosabb helymegjelölés nélkül; flóratérképezési adatok ismertek Debrecen, Monostorpályi, Létavértes, Penészlek, Újléta határából (BARTHA et al. 2021).

Ined.: Debrecen: Nyárfa-lapos-dúlő [8596.4] (DL, 2011), Bodzás-tározótól keletre eső gyepen [8496.4] (DL, 2013, 2018), Tócó-völgy [8395.3] (DL, 2017), Nagycserei Kőrises Arborétum déli oldalán szórványos, északra rekettyés fúzláp szélén is [8496.4] (DL, 2017, 2021); Hajdúsámson: Martinkai-legelőn szórványos [8496.2] (DL, 2013, 2017), Dankótelep rétjén kevés [8396.4] (DL 2021); Létavértes: Falu-rét [8697.1] (DL, 2010, 2018); Monostorpályi: Leány-tó és a Konyári-Kálló között [8696.2] (DL, 2019); Nyírmártonfalva: Lapos-dúlő [8497.1] (DL 2011); Vámospércs: Kőrises-dűlő [8497.2] (DL, 2017).

A faj előfordulása meglehetősen szórványos.

Az érintett KEF-kvadrátok listája: 8395.3, 8396.4, 8496.2, 8496.4, 8497.1, 8497.2, 8596.4, 8696.2, 8697.1

\section{Carex michelii Host.}

Lit.: RAPAICS (1916a): Debrecen: Nagyerdő; RAPAICS (1925): Debreceni Nagyerdő; Soó (1932): Sárándi erdő; Soó (1934): Debrecen: Paci-erdő; Hajdúböszörményi-erdő; Sárándierdő; Hajdúbagosi-erdő; AszóD (1936): Debrecen: Nagyerdő; Soó (1937b): Debrecen: Nagyerdő; KevEY et al. (2017a) cönológiai felvételben: Debrecen: Halápi-erdő; KevEY et al. (2017b) cönológiai felvételekben: Nyíracsád: Jónásrész.

Ined.: Bagamér: Csonka-fűz (ezüsthársas tölgyes) [8597.2] (DL 2020); Debrecen: Álló-hegy [8497.3] (DL 2018), Bánki-erdő és a Diószegi úttól délre is kevés [8596.2] (DL 2016, 2020), Halápi-erdő, a Létai úttól északra öreg „nyíres tölgyesben” [8597.1] (DL 2009), Nagy-Tag egyik tölgyesében [8496.2] (DL 2010, 2013), Halápi-erdő, tölgyes hagyásfoltokban Álló-hegytől keletre a vasút mentén [8497.3] (DL 2013), Halápi-erdő déli részén fiatal tölgyesben [8596.2] (DL, 2020), Bál-hegytől északra [8496.3] (DL 2020), Monostori-erdő, jelentős állományok két tölgyesben [8395.4] (DL 2020); Hajdúbagos: Sưrü tisztája, tölgyesekben elszórt foltokban [8596.3] (DL 2018); Hajdúböszörmény: Városerdő (Gyöngyvirágos tölgyes TT), 3 kis foltban [8395.2] (DL 2018); Hajdúhadház: Csereerdő, tölgyesekben 
többfelé [8395.2] (DL 2019), Nagy-erdő, idős tölgyesekben jelentős állományok [8396.1]

(DL 2020); Nyíracsád: Jónásrész, fekete diós tölgyesben [8497.2] (DL 2019).

Homoki tölgyesek ritka sásfaja a vizsgált területen. Nagyobbnak mondható állománya csak a

Debrecen és Hajdúhadház közötti erdőség néhány idős tölgyes erdőrészletében van.

Az érintett KEF-kvadrátok listája: 8395.2, 8395.4, 8396.1, 8496.2, 8496.3, 8497.2, 8497.3, 8596.2, 8596.3, 8597.1, 8597.2

2649. Carex hordeistichos Vill.

Lit.: Soó \& MÁTHÉ (1938) Debrecen: "Csolnakázótó"; FELFöLDY (2002): Debrecen.

Ined.: Hajdúsámson: Martinkai-legelő, a kereszttöltés mentén, marhák által taposott részen

[8496.2] (DL, 2007); Bagamér: Barcza-tanya (volt TSZ telep) melletti fogyatkozó legelőn

[8597.4] (Molnár Attila 2007).

Az árpasás egyáltalán nem jellemző a Dél-Nyírség homokvidékére. Egyetlen észlelése a Martinkai-legelő egy marhák által taposott mocsárrétjén volt 2007-ben, illetve a következő évben. A két sáscsomót azóta sem láttuk újra. A Bagamérból közölt másik adat az Érmelléki löszös hátról származik, melyet Molnár Attila talált egy közös bejárásunk során.

Az érintett KEF-kvadrátok listája: 8496.2, 8597.4

\section{Carex viridula Michx.}

Lit.: Soó (1934): Hajdúbagos: Csapórét (Carex Oederi néven); SIROKI (1965): Debrecen: Hajdúsámson felé vezető út mellett (Carex Oederi néven); SIROKI (1970): Újléta-Létavértes között (Carex Oederi néven); PAPP et al. (1996/97): Penészlek, Veres-rét (Carex serotina néven); MATUS \& PAPP (2001): Bagamér: Daru-hegyek (magbankvizsgálatból); MATUS \& PAPP (2003): Vámospércs: Villongó, Hajdúsámson: Martinkai-legelő; TöRöK et al. (2009): Hajdúsámson: Martinkai-legelő (Carex oederi néven) magkészletben kimutatva); MATus et al. (2019): Bagamér, Daru-hegyek (Malom-gát) talajmagkészletéből, Hajdúsámson, Martinkai legelő talajmagkészletéből, Vámospércs, Villongó talajmagkészletéből; flóratérképezési adatok ismertek Debrecen, Penészlek, határából (BARTHA et al. 2021).

Ined.: Monostorpályi: A hosszúpályi út mentén a községhatáron levő régi kubikban [8696.2] (DL 2011); Debrecen: Halápi-tározótól nyugatra levő kis tómeder mellett kisebb foltokban [8496.4] (DL 2018).

Minden bizonnyal gyakoribb, mint amit az adataink mutatnak. Erre utalnak MATUS \& PAPP (2001), Тӧвӧк et al. (2009), MATUS et al. (2019) talajmagbank-vizsgálati eredményei is. Az utóbbi 4-5 év nyírségi vízhiánya bizonyára erősen korlátozta a faj megjelenését a korábban alkalmas élőhelyein.

Az érintett KEF-kvadrátok listája: 8496.4, 8696.2

\section{Carex distans L.}

Lit.: RAPAICS (1916a): Debrecen: Pallagon; SIROKI (1970): Újléta-Létavértes között; PAPP et al. (1996/97): Penészlek, Veres-rét; MATUS \& PAPP (2001): Bagamér: Daru-hegyek; MATUS \& PAPP (2003): Vámospércs: Villongó, Hajdúsámson: Martinkai-legelő; PAPP (2010): KékKálló-völgy pontosabb helymegjelölés nélkül; TAKÁCs et al. (2016): Penészlek: Peces-tó; flóratérképezési adatok ismertek Debrecen, Hajdúbagos, Hajdúsámson, Kokad, Nyíradony, Nyírábrány, Penészlek, Téglás határából (BARTHA et al. 2021).

Ined.: Debrecen: Nyárfa-lapos-dűlő [8596.4] (DL 2011), Szepes vasúti megállótól kissé nyugatra [8595.2] (DL 2012), Bellegelő (a repülőtértől délre [8595.2] (DL 2013), Bodzástározótól keletre eső gyepen [8496.4] (DL 2013), Halápi-tározótól délre eső réten [8596.2] (DL 2019), Szepes [8595.4] (DL 2014), Tócó-völgy [8395.3] (DL 2017), Erős-lyuk [8496.2] (DL 2017), Bodzás-tározó melletti rét és a tározó környékén több felé [8496.4] 
(DL 2017, 2018), Nagycsere, a Derecskei-Kálló nyugati oldalága [8496.4] (DL 2018), Hármas-hegy-alja [8496.4] (DL 2018); Hajdúbagos: Földikutya Rezervátum [8596.3] (DL 2011); Hajdúböszörmény: Nagy-Nyerges [8295.1] (DL 2017); Hajdúsámson: Martinkailegelő [8496.2] (DL 2013); Hosszúpályi: Fehértói-tározó északi végénél, valamint Kerekfenék és Kis-Fehér-tó [8696.3] (DL 2011, 2014); Létavértes: Falu-rét [8697.1] (DL 2010); Mikepércs: Nyárfás-hegyi-legelő [8595.4] (DL 2011); Téglás: Lápos-rét [8395.2] (DL 2019).

Az érintett KEF-kvadrátok listája: 8295.1, 8395.2, 8395.3, 8496.2, 8496.4, 8497.3, 8595.2, 8595.4, 8596.2, 8596.3, 8596.4, 8696.3, 8696.4, 8697.1

\section{Kiegészítés a nem észlelt sásfajokról}

Összesen 38 sásfajt észleltünk a vizsgált területen. Akad néhány olyan is, melyeket említenek az irodalmak, de nekünk nem sikerült fellelni. Közéjük tartozik a SIROKI (1970) által 1948-ban a debreceni Sámsoni út menti lápban felfedezett töviskés sás (Carex echinata Murray). Ezt a mostanában rendszeresen és huzamosan kiszáradó élőhelyet számos alkalommal ellenőrizve sem találtuk újra meg. Érdekes viszont, hogy a Nyírség romániai részén ADRELEAN \& KARÁCSONYI (2005) Csomaköz (Ciumeşti), Szaniszló (Sanislău), Ligettanya (Scărişoara Nouă), Piskolt (Pişcolt) és Érkörtvélyes (Curtuiușeni) határából is leírja.

A Soó (1973) által Debrecen-Halápon jelzett fenyérsás (Carex ericetorum Pollich) is a meg nem talált fajok közé tartozik, ahogy a penészleki Veres-rétről (PAPP et al. 1996/97) és a hajdúsámsoni Martinkai-legelőről (MATUS \& PAPP 2003) leírt csőrös sás (Carex rostrata Stokes) is.

A fényes sás (Carex liparicarpos Gaudin) sem került szem elé. Mindössze egy említését ismerjük a vizsgált területről a bagaméri Daru-hegyekről (NAGY et al. 1990). Minden bizonnyal mészkedvelő volta miatt (Soó 1973, LÁJER 2009) nem jellemző a Nyírség mészben szegény homokjára. Érdemes viszont itt is megjegyezni, hogy KARÁcSONYI (1995) a Nyírség keleti peremén jelzi Csanálos (Urziceni), Mezőfény (Foieni) és Karuly puszta (Harea) határából.

A hengeres sás (Carex diandra Schrank) előfordulását PAPP \& DUDÁs (1992) a VámospércsNyíracsád közötti Jónásrészről közli, majd PAPP (2010) a bagaméri Kék-Kálló-völgy északi részén is megtalálta. Mindkét helyen csak néhány szálat említenek. Magunk ezeket a növényeket sem láttuk.

Nem észleltük a berzedt sást (Carex pairaei F.W. Schultz) sem. Úgy véljük, hogy ez a sás egyáltalán nem jellemző a Dél-Nyírségre. Megítélésünk szerint régebbi adatai nagyrészt a LÁJER (2009) szerinti Carex divulsa Stokes subsp. leersii (Kneucker) W. Koch taxonra, vagyis a tölgyes sásra vonatkoznak, ahogy ezt az enumerációban ott kifejtettük. Ezt támasztják alá a herbáriumi anyagon végzett vizsgálataink is. Az eltérést természetesen nem határozási hiba okozza, hanem a bonyodalmas nevezéktani és taxonómiai változások, melyeken a sások e Phaestoglochin szekcióként számontartott csoportja eddig átment (KoOPMAN \& WIĘCŁAW 2017). Persze néhány határozási hiba is előfordul, hiszen a herbáriumban C. spicata példányokat is találtunk ilyen név alatt.

A fekete sást (Carex nigra (L.) Reichard) Soó $(1934,1937 a)$ - „Carex Goodenowii”, majd „Carex nigra var. recta" néven - a debreceni Halápról írja, SiRoKI (1970) - „Carex fusca” néven - Újléta és Létavértes közötti területről, valamint Debrecenben a Sámsoni út menti lápról jelzi. PAPP (2010) a Kék-Kálló-völgyből írja le település megjelölés nélkül, ami szóbeli közlése szerint Bagamér határába esik. A fekete sást sehol nem sikerült fellelnünk, másrészt felvetődött az a lehetőség, hogy a régebbi adatok esetleg részben a gyepes sásra (Carex cespitosa) vonatkozhatnak. Erre utalt az a tény, hogy ez a faj mind Haláp térségében, mind az ÚjlétaLétavértes közötti területen hazai ritkaságához képest jelentős állományokban ma is megta- 
lálható, miközben Soó és Siroki sehol nem említi. A két sásfajjal kapcsolatos nyírségi anomáliára egyébiránt évekkel korábban Lesku Balázs hívta fel a figyelmünket, akitől a fekete sás nyírségi és azon belül a bátorligeti előfordulásáról érdeklődtünk. A régebbi bátorligeti fajlistákkal kapcsolatban (STANDOVÁR et al. in MAHUNKA 1991) ugyanis az említett feltevésre jutott. A kérdést a Debreceni Egyetem Soó Rezső és Siroki Zoltán Herbáriumaiban, valamint a Magyar Természettudományi Múzeum Növénytárában és az ELTE Füvészkert herbáriumában található példányok vizsgálatával igyekszünk jobban megvilágítani. Megítélésünk szerint Siroki Zoltán újlétai anyaga valójában nagyrészt Carex cespitosa példányokat tartalmaz, melyek között sok az atipikus, kettőnél több termős füzérkéjü, illetve feketés színezetű tömlőcskékkel és porzós füzérkével rendelkező egyed. Ilyen feketés színezetű növények ma is előfordulnak a térségben. Másrészt - ahogy korábban már említettük -, egy-egy Halápról és Újlétáról származó lapján $C$. hartmanii példányokat is találtunk a $C$. cespitosa mellett. Sirokinak az 1951-től kezdődően a debreceni Sámsoni úti lápon gyűjtött, „Carex fusca Bell. ap. All.” és „Carex goodenowii Gay." felirattal ellátott példányai között számos van, amit ténylegesen Carex nigra-nak azonosítottunk. Jó néhány olyan példány is akad, melyek megítélésében bizonyos okokból bizonytalanok vagyunk. Közéjük tartoznak a Józsán gyüjtött példányai is. A Sámsoni úti termőhelyről érdemes megjegyezni, hogy megegyezik a Carex echinata egykori termőhelyével. Ez annyira így van, hogy az egyik lapon a $C$. nigra lepréselt csomója között a $C$. echinata példányai is láthatók, míg más lapoknak csak a felirata jelzi ezt a tényt. Soó Rezsőtôl 3 lap szerepel a debreceni gyűjteményben: 1934-ből „Carex Goodenowii” néven Halápról és Bátorligetről, valamint 1947-ből „Carex fusca” felirattal a debreceni Pallagról. Az előbbi kettőt Carex cespitosa-nak azonosítottuk, míg a pallagiról azt godoljuk, hogy valóban Carex nigra. A Magyar Természettudományi Múzeum Növénytárában található egy lap Pénzes Antal 1950es gyűjtéséből Halápról „Carex fusca” felirattal, valamint Soótól két lap 1934-ből szintén Halápról, „Carex Goodenowii” felirattal. Mindhármat Carex cespitosa-ként azonosítottuk. Az ELTE Füvészkert herbáriumában Soótól 1934-ből Bátorligetről és Halápról származó két „Carex Goodenowii" feliratú lapon szerintünk szintén C. cespitosa látható, míg az 1950-ben a debreceni Sámsoni úton gyújtött „Carex fusca” névvel ellátott példányt valóban C. nigra-nak véljük. Ez felveti a gyanúját, hogy a Caricetum Goodenowii társulás Soó (1938) által készített, Bátorligetről és Halápról származó cönológiai felvételei valójában Carex cespitosa állományokban készültek. Mindenesetre ez alátámasztaná LÁJER (2003) kritikus megjegyzését a Soó (1938) és AszóD (1936) által közölt szintetikus fajlisták és a „Caricetum Goodenowii Braun 1915” társulás korábbi leírása között érzékelt eltéréssel kapcsolatban. Összefoglalva tehát úgy véljük, hogy az általunk vizsgált térségből korábban jelzett Carex nigra adatok jelentős részben a Carex cespitosa-ra, néhány esetben pedig a Carex hartmanii-ra vonatkoznak. Másrészt a Carex nigra hajdani Debrecen környéki előfordulására is bizonyítékot adnak a herbáriumi lapok. A Sámsoni úti lápot az évek során többször is bejártuk, de ezt a fajt nem találtuk. Pallag környékén pedig jelenleg nem ismerünk számára alkalmasnak tűnő élőhelyet. A PAPP (2010) által leírt bagaméri növényeket sem sikerült még megtalálnunk. További adalék a témához, hogy a homokvidék romániai részén a Fülöppel és Penészlekkel átellenben található Piskolt (Pişcolt) határából KARÁcSONYI (1995), illetve ADRELEAN \& KARÁcSONYI (2005) rögzíti a fekete sás előfordulását, de a gyepes sást is leírják a Bátorliget közelében levő Csanálosról (Urziceni).

\section{Köszönetnyilvánítás}

Köszönjük Lovas-Kiss Ádámnak, hogy Carex hartmanii adatának, Molnár Attilának, hogy Carex hordeistichos adatának és Lisztes Annának, hogy Carex cespitosa adatának közlését átengedte. Köszönjük Takács Attilának a herbáriumi példányok áttekintésében nyújtott segít- 
ségét, és azt, hogy a Magyar Természettudományi Múzeum Növénytárában a számunkra szükséges lapokat lefényképezte. Tökölyi Jácintot pedig az irodalom beszerzésében nyújtott segítségéért illeti köszönet. Köszönjük a bírálók konstruktív javaslatait és Lesku Balázs hasznos észrevételeit.

\section{Irodalom}

ADRELEAN G. \& KARÁCSONYI K. (2005): Flora, vegetaţia, fauna şi ecologia nisipurilor din nord-vestul României. - Editura Daya, Satu Mare.

AszóD L. (1936): Adatok a nyírségi homoki vegetáció ökológiájához és szociológiájához. - Acta Geobotanica Hungarica 1(1): 75-107.

BARTHA D. (1988): A hajdúböszörményi Városerdő érdekesebb növényfajai. - Természettudományos Tájékoztató 2(1): 5-11.

Bartha D., Király G., Schmidt D., Tiborcz V., Barina Z., Csiky J., JaKAB G., Lesku B., Schmotzer A., VidÉKi R., VojtKó A. \& ZólYOMi Sz. (szerk.) (2015): Magyarország edényes növényfajainak elterjedési atlasza. Nyugat-magyarországi Egyetem Kiadó, Sopron, pp. 266-274.

BARTHA D., BÁN M., SChMidT D. \& TiBorCz V. (2021): Magyarország edényes növényfajainak online adatbázisa (http://floraatlasz.uni-sopron.hu). - Soproni Egyetem, Erdőmérnöki Kar, Növénytani és Természetvédelmi Intézet. (Hozzáférés: 2021. 07. 24.)

Boros Á. (1932): A Nyírség flórája és növényföldrajza. - A Debreceni Tisza István Tudományos Társaság Honismertető Bizottságának kiadványai 7(25-26): 54-57.

DEMETER L. \& SzÉL L. (2014): Dél-Nyírségi tájak őrzője: a Hajdúsági Tájvédelmi Körzet. - Természetbúvár 66(4): 20-23.

Demeter L. (2018): A Calamagrostis stricta (Timm) Koeler elterjedése a Dél-Nyírségben - Kitaibelia 23(2): 188-196.

DövÉNYI Z. (szerk.) (2010): Magyarország kistájainak katasztere. - MTA Földrajztudományi Kutató Intézet, Budapest.

FELFÖLDY L. (2002): Sás-határozó. - Kitaibelia 7(1): 1-100.

JAKAB G. \& LESKU B. (1996) Egy újabb ősláp a Nyírségben: A piricsei Júlia-liget botanikai értékei I. Kitaibelia 1: 46-55.

JávorKA S. (1962): Növényhatározó II. kötet - Harasztok - Virágos növények. - Tankönyvkiadó, Budapest.

KARÁCSONYI K. (1995): Flora şi vegetaţia județului Satu Mare. - Editura Muzeului Sătmărean, Satu Mare.

Kevey B., PAPP L. \& LendVAi G. (2017a): A Nyírség tölgy-kőris-szil ligetei (Fraxino pannonicae-Ulmetum Soó in Aszód 1935 corr. Soó 1963). - Kitaibelia 22(1): 179-220.

Kevey B., PAPP L. \& Lendvai G. (2017b): A Nyírség gyertyános-tölgyesei (Convallario-Carpinetum Kevey 2008). - Botanikai Közlemények 104(1): 147-164.

KIRÁLY G. (szerk.) (2009): Új magyar füvészkönyv. Magyarország hajtásos növényei. Határozókulcsok. Aggteleki Nemzeti Park Igazgatóság, Jósvafő.

KoOpMAn J. \& WięCŁaW H. (2017): The section Phaestoglochin (Carex, Cyperaceae) in the Netherlands. Gorteria 39: 79-87.

Koopman J. (2015): Lectotypification of Carex nemorosa var. cuprina and clarification of C. cuprina (Cyperaceae). - Willdenowia 45: 97-101.

Korda M., Schmidt D., VidéKi R., Haszonits Gy., Tiborcz V., Csiszár Á., ZaGyvai G. \& Bartha D. (2017): A Gagea minima (L.) Ker Gawl. és a Dictamnus albus L. újrafelfedezése a Dél-Tiszántúlon, valamint további florisztikai adatok az Alföldről. - Kitaibelia 22(2): 304-316.

LÁjER K. (1998): Az Aldrovanda vesiculosa L. újabb előfordulása és egyéb adatok Magyarország flórájának ismeretéhez. - Kitaibelia 3(2): 263-274.

LÁJER K. (2003): A Caricetum buekii, Caricetum cespitosae, Caricetum paniceo-nigrae, Cirsietum rivularis és Sagittario-Sparganietum emersi hazai előfordulásáról. - Kitaibelia 8(1): 35-42.

LÁJER K. (2009): Cyperaceae - Palkafélék családja. - In: KIRÁLY G. (szerk.), Új magyar füvészkönyv. Magyarország hajtásos növényei. Határozókulcsok. Aggteleki Nemzeti Park Igazgatóság, Jósvafő, p. 558.

Matus G. \& PAPP M. (2001): Újabb adatok a bagaméri Daruhegyek (Dél-Nyírség) flórájához. - Kitaibelia 4(2): 363-369.

MATUS G. \& PAPP M. (2003): Adatok Hajdúsámson és Vámospércs környékének (Dél-Nyírség) flórájához. - Kitaibelia 8(1): 99-112. 
Matus G., Aszalós R., Dorotovič Cs., HanyicsKa M., Hűvös-Récsi A., Musicz L., Miglécz T., PAPP M., Schmotzer A., TöröK P., VALKó O., VojtKó A., HARTMAnN J., TAKÁCs A. \& BALOGH R. (2019): Kiegészítések a magyar flóra ismeretéhez. - Botanikai Közlemények 106(1): 71-112.

MATUS G., PAPP M. \& TóTHMÉRÉSz B. (2005): Impact of management on vegetation dynamics and seed bank formation of inland dune grassland in Hungary. - Flora 200: 296-306.

MÉszÁRos F.-NÉ DRASKovits R. (1968): A Carex otrubae Podp. Magyarországon. - Botanikai Közlemények 55(1): 31-36.

MolinA A., ACEDo C. \& LlAMAS F. (2008a): Taxonomy and new taxa of the Carex divulsa aggregate in Eurasia (section Phaestoglochin, Cyperaceae). - Botanical Journal of the Linnean Society 156: 385-409.

Molina A., Acedo C. \& Llamas F. (2008b): (1817) Proposal to conserve the name Carex leersii F.W. Schultz against $C$. leersii Willd. and C. chabertii (Cyperaceae). - Taxon 57(2): 648-649.

NAGY M., PAPP M., SZABó L., BodnÁR T. \& PRÉCSÉNYI I. (1990): Flora and fauna of Daru Hills. - Acta Biologica Debrecina Suppl. 22: 13-24.

PAPP L. \& DuDÁS M. (1988): Adatok a Közép-, a Dél-Nyírség és környékének botanikai értékeiről I. Calandrella 2(2): 5-25.

PAPP L. \& DuDÁs M. (1989): Adatok a Közép-, a Dél-Nyírség és környékének botanikai értékeiről II. Calandrella 3(2): 13-33.

PAPP L. \& DudÁs M. (1990): Adatok a Közép-, a Dél-Nyírség és környékének botanikai értékeiről III. Calandrella 4: 5-33.

PAPP L. \& DudÁs M. (1992): Data on Botanical Values of Central and South Nyírség and their Vicinity. - $A$ Debreceni Déry Múzeum 1989-1990. évi évkönyve. pp. 7-35.

PAPP L. (1989): A debreceni Nagyerdő növénytársulásai és flórája. - Calandrella (Nagyerdei különszám): 19-32.

PAPP L. (2003): Vámospércs-Nyíracsád Jónás rész tanösvény. - Dél-Nyírség-Bihari Tájvédelmi Egyesület, Debrecen, pp. 8-13.

PAPP L. (2010): Flóra és vegetáció. - In: PAPP L. (szerk.), A Kék-Kálló völgyének természeti értékei. DélNyírség-Bihari Tájvédelmi és Kulturális Értékőrző Egyesület, Túrkeve-Budapest, pp. 11-27.

PAPP M., HAMVAS-Mikó M. \& NAGY M. (1996/97): Floristical and phytocoenological studies on the pasture of village Penészlek (Northeast Hungary). - Acta Botanica Hungarica 40(1-4): 167-192.

RAPAICS R. (1916a): Debrecen flórája. - Erdészeti Kísérletek 18: 28-80.

RAPAICS R. (1916b): A debreceni homokterület növényzeti viszonyai. - Erdészeti Kísérletek 18: 124-165.

RAPAICS R. (1925): A Nyírség növényföldrajza. - A Debreceni Tisza István Tudományos Társaság Honismertető Bizottságának Közleményei 1(2): 74-115.

Simon T. (2000): A magyarországi edényes flóra határozója. Harasztok - Virágos növények. - Nemzeti Tankönyvkiadó, Budapest.

SIROKI Z. (1965): Újabb florisztikai adatok hazánk területéről. - Botanikai Közlemények 52(1): 31-34.

SIRоKI Z. (1970): A lápi nádtippan Calamagrostis neglecta (Ehrh) G.M. Sch. új lelőhelye és elterjedése a Nyírségen. - A Debreceni Déri Múzeum 1976. évi Évkönyve. pp. 15-20.

Soó R. \& MÁTHÉ I. (1938): A Tiszántúl flórája. Flora Planitiei Hungariae Transtibiscensis. - Editio Instituci Botanici Universitatis Debreceniensis.

Soó R. (1932): Debrecen növényvilágának kutatása (Újabb adatok Hajdúmegye flórájának ismeretéhez.). - Debreceni Szemle 6: 216-225.

Soó R. (1933): „Modern növényföldrajz és egyéb, ami hozzá járul” (Zárszavam Boros Ádám flóramúvéhez). - Debreceni Szemle 7: 335-339.

Soó R. (1934): Nyírség-kutatásunk florisztikai eredményei. - Botanikai Közlemények 31(5-6): 218-252.

Soó R. (1937a): Pótlékok Nyírségi flórakutatásunk eredményihez. - Botanikai Közlemények 34(1-2): 1-12.

Soó R. (1937b): A Nyírség erdői és erdőtípusai. - Erdészeti Kísérletek 39: 337-380.

Soó R. (1938): Vízi, mocsári és réti növényszövetkezetek a Nyírségben. - Botanikai Közlemények 35(56): 249-273.

Soó R. (1939): Pótlékok Nyírségi flórakutatásunk eredményihez II. - Botanikai Közlemények 36(5-6): 307-312.

Soó R. (1942): Pótlékok nyírségi és tiszántúli flórakutatásunk eredményeihez III. - Botanikai Közlemények 39(12): 45-56.

Soó R. (1948): Tiszántúli flórakutatásunk újabb eredményei. Pótlások Soó-Máthé Tiszántúl flórájához V. - Borbásia 8(18): 48-57. 
Soó R. (1973): A magyar flóra és vegetáció rendszertani-növényföldrajzi kézikönyve V. - Akadémiai Kiadó, Budapest, pp. 206-261.

StAndováR T., Tóth Z. \& Simon T. (1991): Vegetetion of the Bátorliget mire Reserve. - In: MAHunKa S. (szerk.), The Bátorliget Nature Reserves - after forty years. Hungarian Natural History Museum, Budapest, pp. 57-118.

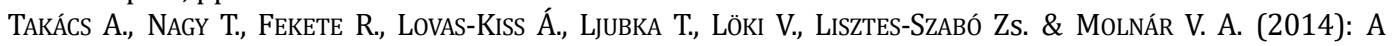
Debreceni Egyetem Herbáriumának Adatbázisa I.: A „Soó Rezső Herbárium”. - Kitaibelia 19(1): 142-155.

TAKács A., NAgY T., SRAmkó G., Lovas-Kiss Á., SÜVEges K., LuKÁcs B. A., FEKETE R., LÖKI V., MaLATinszky Á., E. VojtKó A., Koscsó J., Pfliegler W. P., NótáRi K. \& Molnár V. A. (2016): Pótlások a Magyarország edényes növényfajainak elterjedési atlaszához I. - Kitaibelia 21(1): 101-115.

TÖRÖK P., PAPP M., TóTHMÉRÉSZ B. \& MATUS G. (2009): Lúdlegelést követően regenerálódó nyírségi homoki gyepek magkészlete. - Természetvédelmi Közlemények 15: 134-146.

Turland N. J., Wiersema J. H., Barrie F. R., Greuter W., Hawksworth D. L., Herendeen P. S., Knapp S., Kusber W.-H., Li D.-Z., Marhold K., May T. W., McNeill J., Monro A. M., Prado J., Price M. J. \& Smith G. F. (eds) (2018): International Code of Nomenclature for algae, fungi, and plants (Shenzhen Code) adopted by the Nineteenth International Botanical Congress Shenzhen, China, July 2017. Regnum Vegetabile 159. Glashütten: Koeltz Botanical Books.

Beérkezett / received: 2021. 03. 30. • Elfogadva / accepted: 2021. 08. 28. 
DEMETER \& SzÉL (2021): Adatok a sásfajok előfordulásához a Dél-Nyírségben és környékén

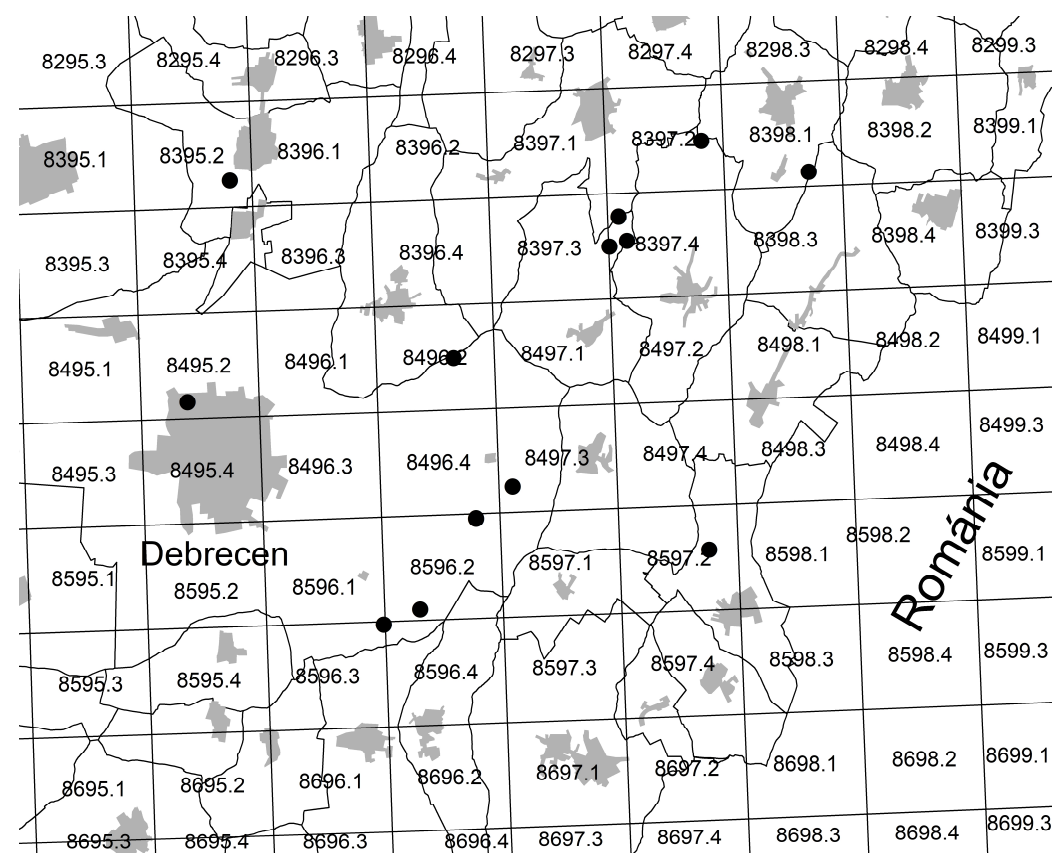

2. ábra A rezgő sás (Carex brizoides) észlelt előfordulási helyei a közép-európai flóratérképezés hálórendszerének (KEF) kvadrátjaival

Fig. 2 Occurrences of Carex brizoides with the quadrates of the Central European flora mapping system (CEU)

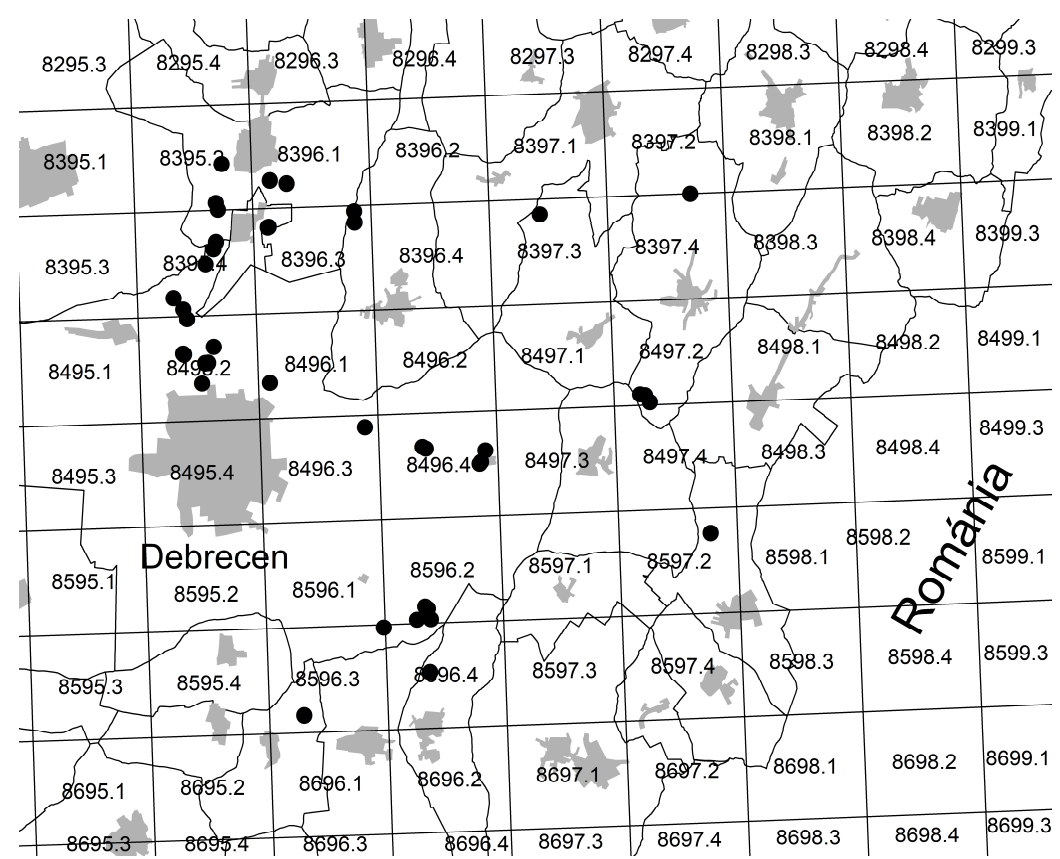

3. ábra A zöldes sás (Carex divulsa subsp. divulsa) észlelt előfordulási helyei a közép-európai flóratérképezés hálórendszerének (KEF) kvadrátjaival

Fig. 3 Occurrences of Carex divulsa subsp. divulsa with the quadrates of the Central European flora mapping system (CEU) 
Kitaibelia 26(2): 165-198.

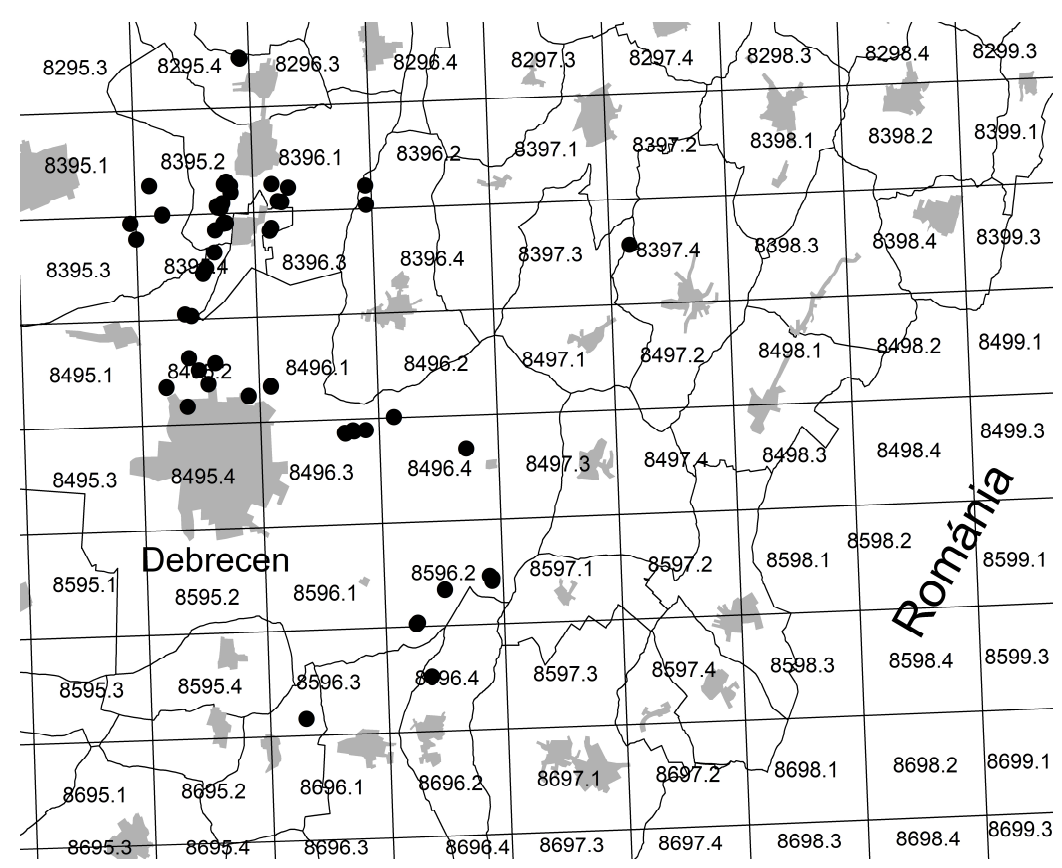

4. ábra A tölgyes sás (Carex divulsa subsp. leersii) észlelt előfordulási helyei a közép-európai flóratérképezés hálórendszerének (KEF) kvadrátjaival

Fig. 4 Occurrences of Carex divulsa subsp. leersii with the quadrates of the Central European flora mapping system (CEU)

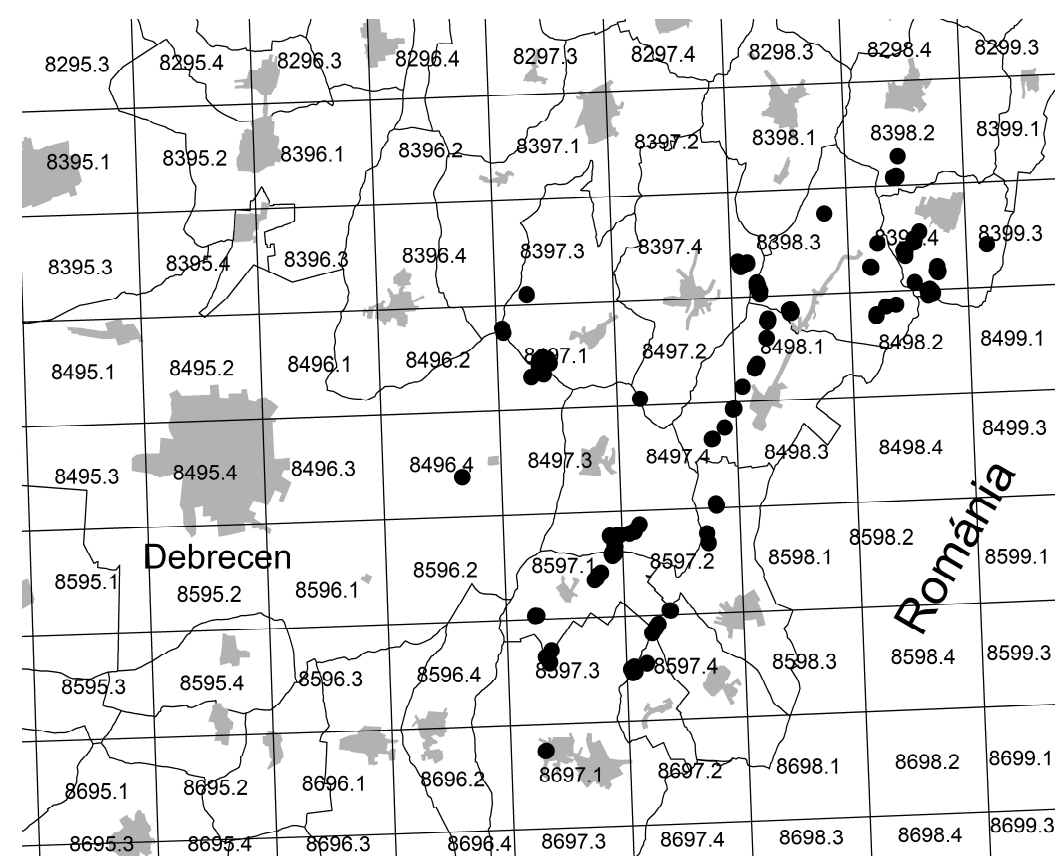

5. ábra A rostostövű sás (Carex appropinquata) észlelt előfordulási helyei a közép-európai flóratérképezés hálórendszerének (KEF) kvadrátjaival

Fig. 5 Occurrences of Carex appropinquata with the quadrates of the Central European flora mapping system (CEU) 
DEMETER \& SzÉL (2021): Adatok a sásfajok előfordulásához a Dél-Nyírségben és környékén

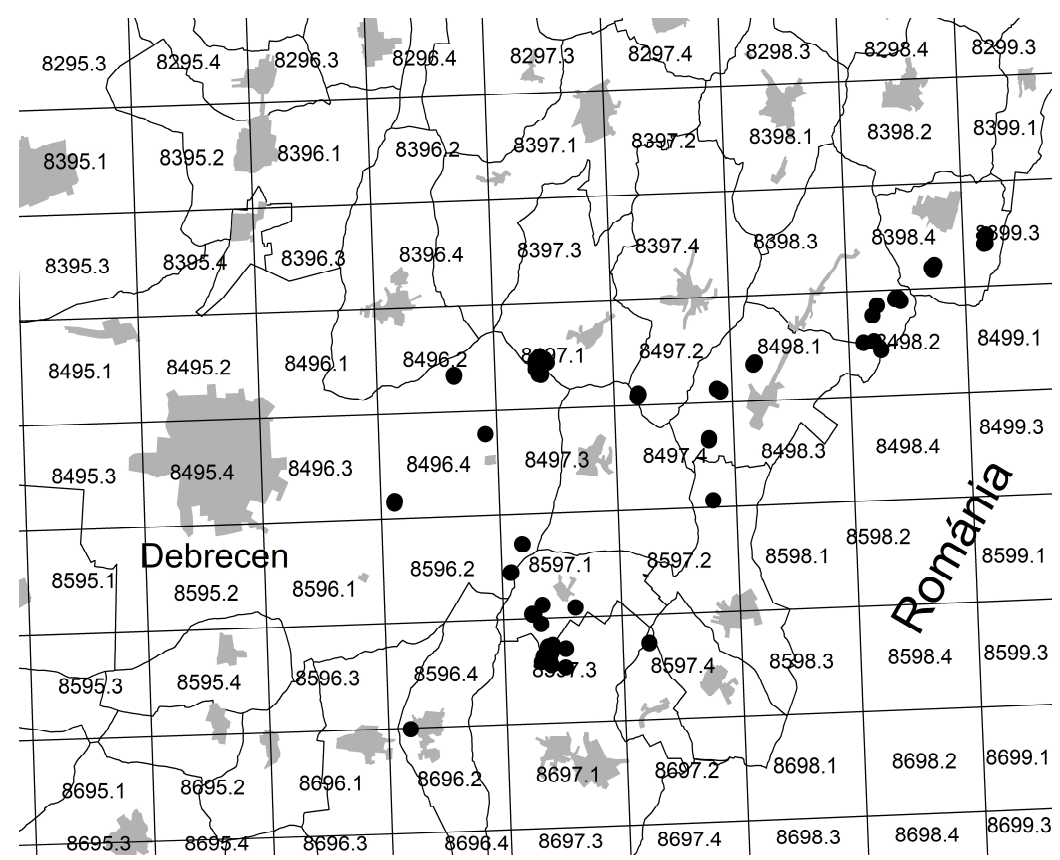

6. ábra A gyepes sás (Carex cespitosa) észlelt előfordulási helyei a közép-európai flóratérképezés hálórendszerének (KEF) kvadrátjaival

Fig. 6 Occurrences of Carex cespitosa with the quadrates of the Central European flora mapping system (CEU)

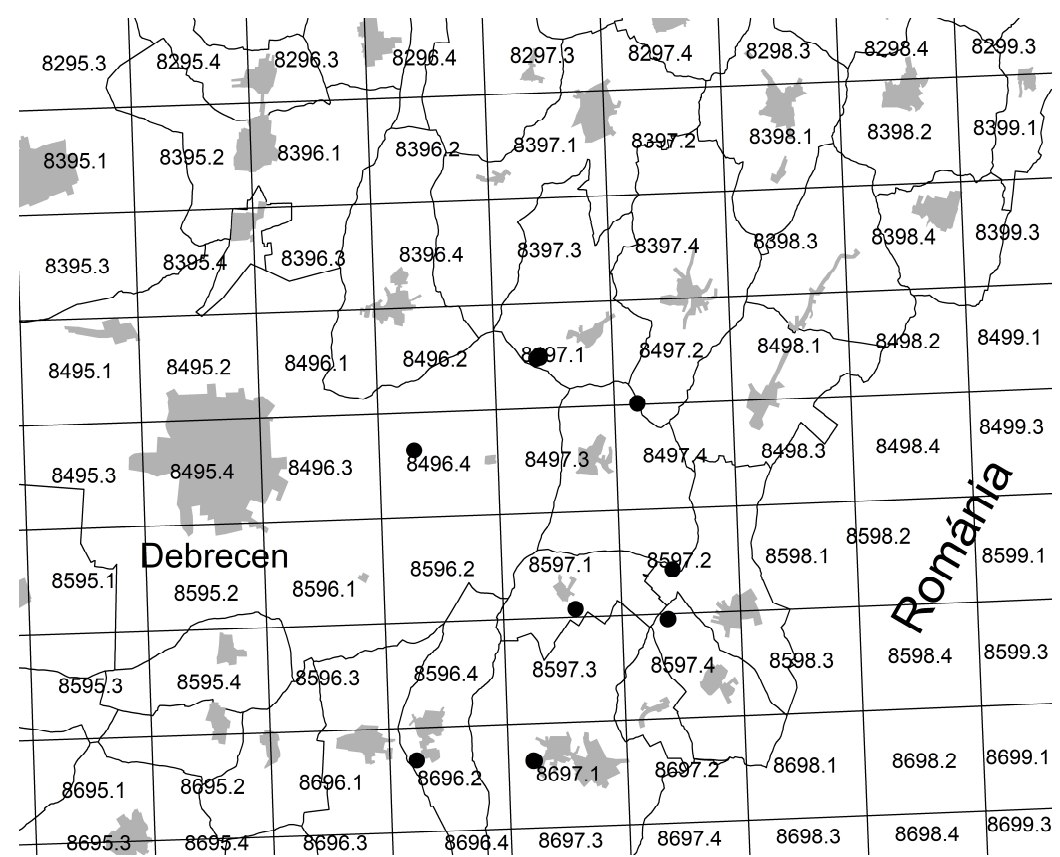

7. ábra Az északi sás (Carex hartmanii) észlelt előfordulási helyei a közép-európai flóratérképezés hálórendszerének (KEF) kvadrátjaival

Fig. 7 Occurrences of Carex hartmanii with the quadrates of the Central European flora mapping system (CEU) 
Kitaibelia 26(2): 165-198.

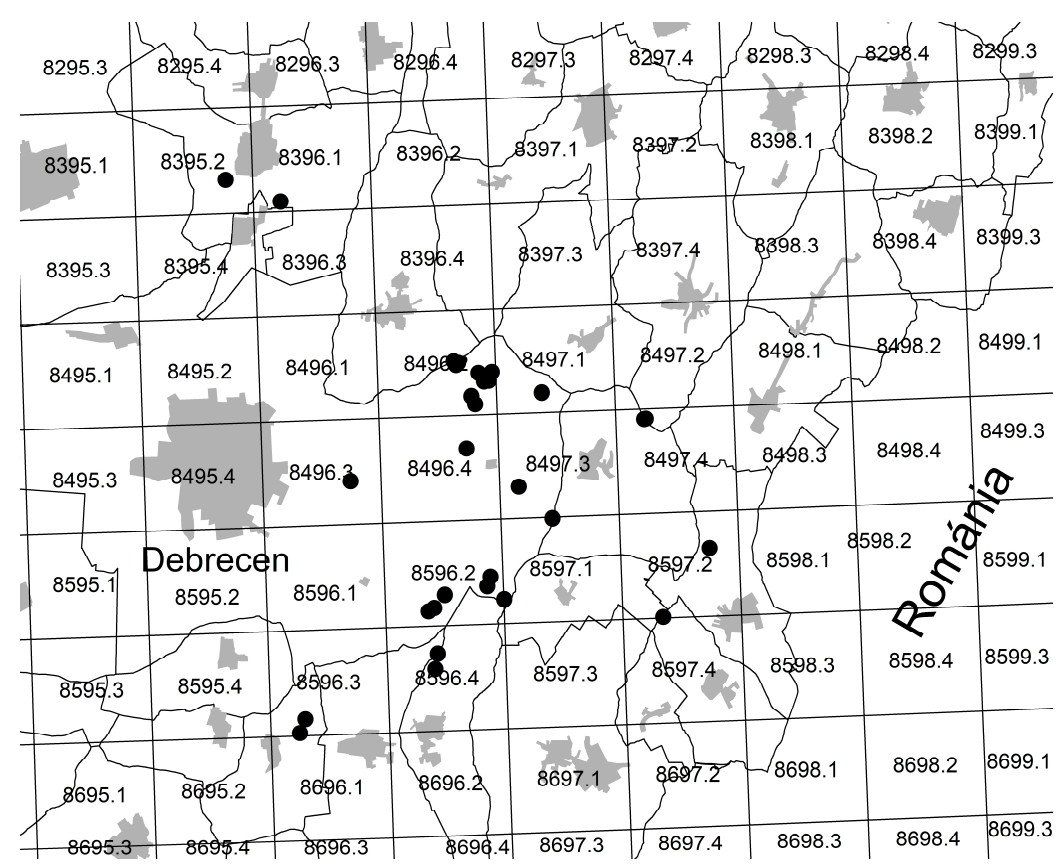

8. ábra A sápadt sás (Carex pallescens) észlelt előfordulási helyei a közép-európai flóratérképezés hálórendszerének (KEF) kvadrátjaival

Fig. 8 Occurrences of Carex pallescens with the quadrates of the Central European flora mapping system (CEU)

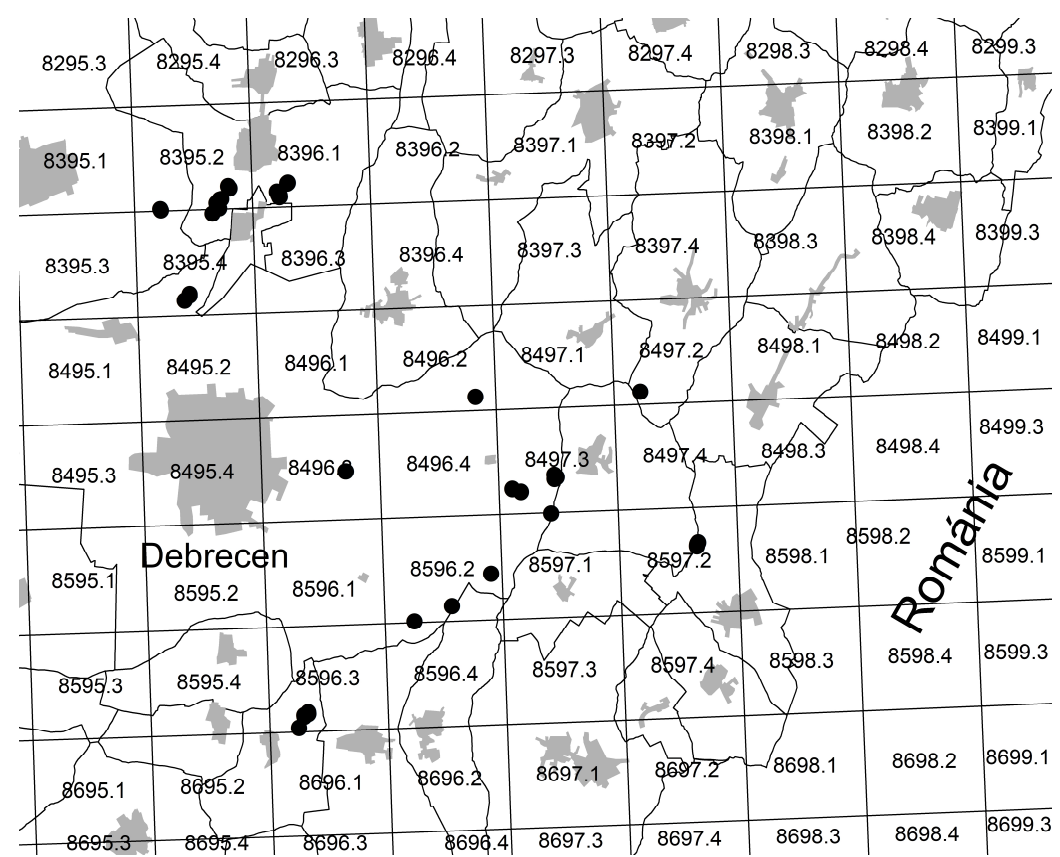

9. ábra A sárgás sás (Carex michelii) észlelt előfordulási helyei a közép-európai flóratérképezés hálórendszerének (KEF) kvadrátjaival

Fig. 9 Occurrences of Carex michelii with the quadrates of the Central European flora mapping system (CEU) 


\section{Elektronikus melléklet}

e1. ábra Carex remota, Debrecen-Nagycsere, Kőrises Arborétum, 2020 / Fig. e1 Carex remota, Debrecen-Nagycsere, Kőrises Arborétum, 2020. e2. ábra Carex ovalis, Nyírábrány, Keszler-tag, 2018 / Fig. e2 Carex ovalis, Nyírábrány, Keszler-tag, 2018. e3. ábra Carex praecox, Monostorpályi, Monostorpályi-legelő, 2010 / Fig. e3 Carex praecox, Monostorpályi, Monostorpályi-legelő, 2010. e4. ábra Carex brizoides, Debrecen, Mézeshegyi-tölgyes, 2013 / Fig. e4 Carex brizoides, Debrecen, Mézeshegyi-tölgyes, 2013. e5. ábra Carex brizoides, Nyírmártonfalva, Berek-szilas, 2021 / Fig. e5 Carex brizoides, Nyírmártonfalva, Berek-szilas, 2021. e6. ábra Carex brizoides, Bagamér, Nagy-erdő, 2021 / Fig. e6 Carex brizoides, Bagamér, Nagy-erdő, 2021. e7. ábra Carex elongata, Álmosd, Daru-láp, 2011 / Fig. e7 Carex elongata, Álmosd, Daru-láp, 2011. e8. ábra Carex elongata, Létavértes, Toszorka-rét, 2012 / Fig. e8 Carex elongata, Létavértes, Toszorka-rét, 2012. e9. ábra Carex elongata, Debrecen, Hármashegy alja, 2017 / Fig. e9 Carex elongata, Debrecen, Hármas-hegy alja, 2017. e10. ábra Carex divulsa subsp. divulsa, Debrecen-Nagycsere, Kőrises Arborétum, 2020 / Fig. e10 Carex divulsa subsp. divulsa, Debrecen-Nagycsere, Kőrises Arborétum, 2020. e11. ábra Carex divulsa subsp. leersii, DebrecenNagycsere, Kőrises Arborétum, 2020 / Fig. e11 Carex divulsa subsp. leersii, Debrecen-Nagycsere, Kőrises Arborétum, 2020. e12. ábra Carex divulsa subsp. leersii, Debrecen, Nagyerdő, 2020 / Fig. e12 Carex divulsa subsp. leersii, Debrecen, Nagyerdő, 2020. e13. ábra Carex divulsa subsp. leersii, Hajdúhadház, Csereerdő, 2020 / Fig. e13 Carex divulsa subsp. leersii, Hajdúhadház, Csereerdő, 2020. e14. ábra Carex divulsa subsp. leersii tömlőcskéi, Hajdúböszörmény, 2020 / Fig. e14 Utricles of Carex divulsa subsp. leersii, Hajdúböszörmény, 2020. e15. ábra Carex spicata, Debrecen, Bánki-erdő, 2018 / Fig. e15 Carex spicata, Debrecen, Bánki-erdő, 2018. e16. ábra Carex spicata tömlőcskéi, Hajdúhadház, Csereerdő, 2020 / Fig. e16 Utricles of Carex spicata, Hajdúhadház, Csereerdő, 2020. e17. ábra Carex spicata gyökere, Debrecen, Bánki-erdő, 2020 / Fig. e17 Roots of Carex spicata, Debrecen, Bánki-erdő, 2020. e18. ábra Carex vulpina, Hosszúpályi, Kis-Fehér-tó, 2010 / Fig. e18 Carex vulpina, Hosszúpályi, Kis-Fehér-tó, 2010. e19. ábra Carex otrubae, Debrecen, Nyárfa-lapos-dűlő, 2011 / Fig. e19 Carex otrubae, Debrecen, Nyárfa-lapos-dűlő, 2011. e20. ábra Carex otrubae, Debrecen-Nagycsere, Kőrises Arborétum, 2019 / Fig. e20 Carex otrubae, Debrecen-Nagycsere, Kőrises Arborétum, 2019. e21. ábra Carex paniculata, Kokad, Daru-láp, 2009 / Fig. e21 Carex paniculata, Kokad, Daru-láp, 2009. e22. ábra Carex paniculata, Kokad, Álmosd-Kokadi-tározó, 2010 / Fig. e22 Carex paniculata, Kokad, ÁlmosdKokadi-tározó, 2010. e23. ábra Carex paniculata, Bagamér, Fehérföld-sziget, 2019 / Fig. e23 Carex paniculata, Bagamér, Fehérföld-sziget, 2019. e24. ábra Carex appropinquata, Nyírábrány, Teleki-legelő, 2011 / Fig. e24 Carex appropinquata, Nyírábrány, Teleki-legelő, 2011. e25. ábra Carex appropinquata, Nyíracsád, Rikács, 2015 / Fig. e25 Carex appropinquata, Nyíracsád, Rikács, 2015. e26. ábra Carex disticha, Debrecen-Nagycsere, 2018 / Fig. e26 Carex disticha, Debrecen-Nagycsere, 2018. e27. ábra Carex stenophylla, Hosszúpályi, Fehértói-tározó, 2010 / Fig. e27 Carex stenophylla, Hosszúpályi, Fehértói-tározó, 2010. e28. ábra Carex divisa, Debrecen, Bellegelő, 2013 / Fig. e28 Carex divisa, Debrecen, Bellegelő, 2013. e29. ábra Carex elata, Hajdúsámson, Martinkai-legelő, 2013 / Fig. e29 Carex elata, Hajdúsámson, Martinkai-legelő, 2013. e30. ábra Carex cespitosa, Debrecen, Halápi-erdő, 2009 / Fig. e30 Carex cespitosa, Debrecen, Halápi-erdő, 2009. e31. ábra Carex cespitosa, Nyírmártonfalva, Lapos-dűlő, 2013 / Fig. e31 Carex cespitosa, Nyírmártonfalva, Lapos-dúlő, 2013. e32. ábra Carex cespitosa, feketés színezetű példány, Debrecen, Halápi-erdő, 2014 / Fig. e32 Black-coloured specimen of Carex cespitosa, Debrecen, Halápi-erdő, 2014. e33. ábra Carex cespitosa, Debrecen, Hármas-hegy alja, 2017 / Fig. e33 Carex cespitosa, Debrecen, Hármas-hegy alja, 2017. e34. ábra Carex cespitosa, Nyíracsád, Jónásrész, 2017 / Fig. e34 Carex cespitosa, Nyíracsád, Jónásrész, 2017. e35. ábra Carex cespitosa jellegzetes fahéjszínű porzói, Debrecen, Nagy-dűlő, 2014 / Fig. e35 Carex cespitosa with characteristic cinnamon stamens, Debrecen, Nagy-dűlő, 2014. e36. ábra Carex hartmanii, Újléta, Hegyalja, 2011 / Fig. e36 Carex hartmanii, Újléta, Hegyalja, 2011. e37. ábra Carex hartmanii, Újléta, Hegyalja, 2010 / Fig. e37 Carex hartmanii, Újléta, Hegyalja, 2010. e38. ábra Carex hartmanii, Nyírmártonfalva, Lapos-dűlő, 2011 / Fig. e38 Carex hartmanii, Nyírmártonfalva, Lapos-dűlő, 2011. e39. ábra Carex hartmanii, Debrecen, Nagycsere, 2018 / Fig. e39 Carex hartmanii, Debrecen, Nagycsere, 2018. e40. ábra Carex buxbaumii, Vámospércs, Kőrises-dűlő (Jónásrész), 2012 / Fig. e40 Carex buxbaumii, Vámospércs, Kőrises-dűlő (Jónásrész), 2012. e41. ábra Carex buxbaumii tömlőcskéjének csőre, Vámospércs, Kőrises-dűlő (Jónásrész), 2011 / Fig. e41 Beak of utricle of Carex buxbaumii, Vámospércs, Kőrises-dűlő (Jónásrész), 2011. e42. ábra Carex buxbaumii, Vámospércs, Kőrises-dűlő (Jónásrész), 2011 / Fig. e42 Carex buxbaumii, Vámospércs, Kőrises-dűlő (Jónásrész), 2011. e43. ábra 
Carex buxbaumii, Vámospércs, Kőrises-dűlő (Jónásrész), 2011 / Fig. e43 Carex buxbaumii, Vámospércs, Kőrises-dúlő (Jónásrész), 2011. e44. ábra Carex flacca, Monostorpályi, Monostorpályi-legelő, 2019 / Fig. e44 Carex flacca, Monostorpályi, Monostorpályi-legelő, 2019. e45. ábra Carex humilis, Bagamér, Malomgát (Daru-hegyek), 2015 / Fig. e45 Carex humilis, Bagamér, Malomgát (Daru-hegyek), 2015. e46. ábra Carex umbrosa, Nyírábrány, Káposztás-lapos, 2010 / Fig. e46 Carex umbrosa, Nyírábrány, Káposztás-lapos, 2010. e47. ábra Carex umbrosa, Bagamér, Silye-rét, 2010 / Fig. e47 Carex umbrosa, Bagamér, Silye-rét, 2010. e48. ábra Carex umbrosa, Újléta, Bank-lapos, 2011 / Fig. e48 Carex umbrosa, Újléta, Bank-lapos, 2011. e49. ábra Carex caryophyllea, Bagamér, Malomgát (Daru-hegyek), 2017 / Fig. e49 Carex caryophyllea, Bagamér, Malomgát (Daru-hegyek), 2017. e50. ábra Carex caryophyllea, Debrecen, Bánki-erdő, 2016 / Fig. e50 Carex caryophyllea, Debrecen, Bánki-erdő, 2016. e51. ábra Carex tomentosa, Monostorpályi, Leány-tó, 2019 / Fig. e51 Carex tomentosa, Monostorpályi, Leány-tó, 2019. e52. ábra Carex pseudocyperus, Nyírmártonfalva, Lapos-dűlő, 2011 / Fig. e52 Carex pseudocyperus, Nyírmártonfalva, Lapos-dûlő, 2011. e53. ábra Carex pallescens, Monostorpályi, Monostorpályi-legelő, 2019 / Fig. e53 Carex pallescens, Monostorpályi, Monostorpályi-legelő, 2019. e54. ábra Carex supina, Bagamér, Malomgát (Daru-hegyek), 2017 / Fig. e54 Carex supina, Bagamér, Malomgát (Daru-hegyek), 2017. e55. ábra Carex vesicaria, Fülöp, Százholdas, 2013 / Fig. e55 Carex vesicaria, Fülöp, Százholdas, 2013. e56. ábra Carex melanostachya, Hajdúbagos, Földikutya Rezervátum, 2011 / Fig. e56 Carex melanostachya, Hajdúbagos, Földikutya Rezervátum, 2011. e57. ábra Carex panicea, Hajdúsámson, Martinkai-legelő, 2013 / Fig. e57 Carex panicea, Hajdúsámson, Martinkailegelő, 2013. e58. ábra Carex michelii, Nyíracsád, Jónásrész, 2019 / Fig. e58 Carex michelii, Nyíracsád, Jónásrész, 2019. e59. ábra Carex michelii, Debrecen, Nagy-tag, 2013 / Fig. e59 Carex michelii, Debrecen, Nagy-tag, 2013. e60. ábra Carex michelii, Debrecen, Halápi-erdő, 2013 / Fig. e60 Carex michelii, Debrecen, Halápi-erdő, 2013. e61. ábra Carex viridula, Debrecen, Halápi-tározó, 2020 / Fig. e61 Carex viridula, Debrecen, Halápi-tározó, 2020. e62. ábra Siroki Zoltán herbáriumi lapja (DE) 1954ből, melyen a Carex nigra és Carex echinata együtt látható / Fig. e62 Zoltán Siroki's herbarium specimen (DE) from 1954, in which Carex nigra and Carex echinata can be seen together 
DEMETER L. \& SzÉL L. (2021):

Adatok a sásfajok (Carex, Cyperaceae) előfordulásához a Dél-Nyírségben és környékén / Data on the occurrence of sedge species (Carex, Cyperaceae) in and around South Nyírség (East Hungary)

Kitaibelia 26(2): 165-198.

DOI: $10.17542 /$ kit.26.165

Elektronikus melléklet / Electronic appendix

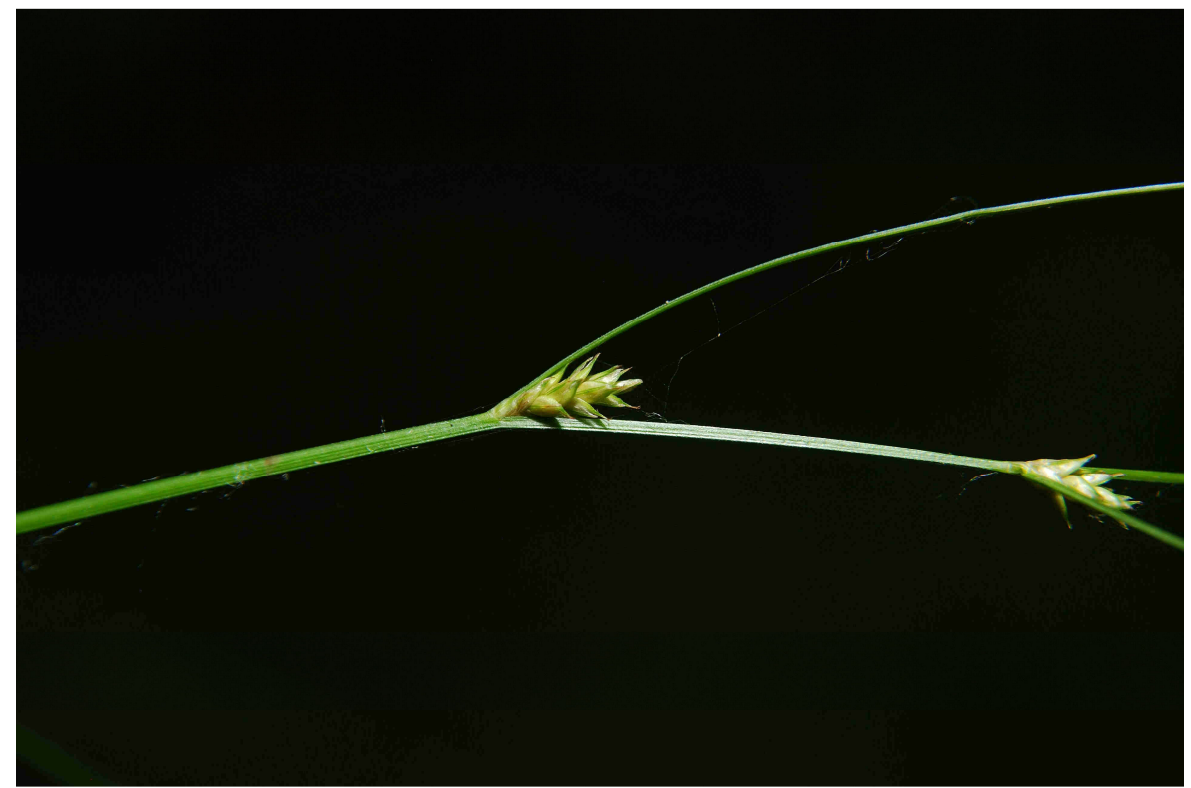

e1. ábra Carex remota, Debrecen-Nagycsere, Kőrises Arborétum, 2020 Fig. e1 Carex remota, Debrecen-Nagycsere, Kőrises Arborétum, 2020

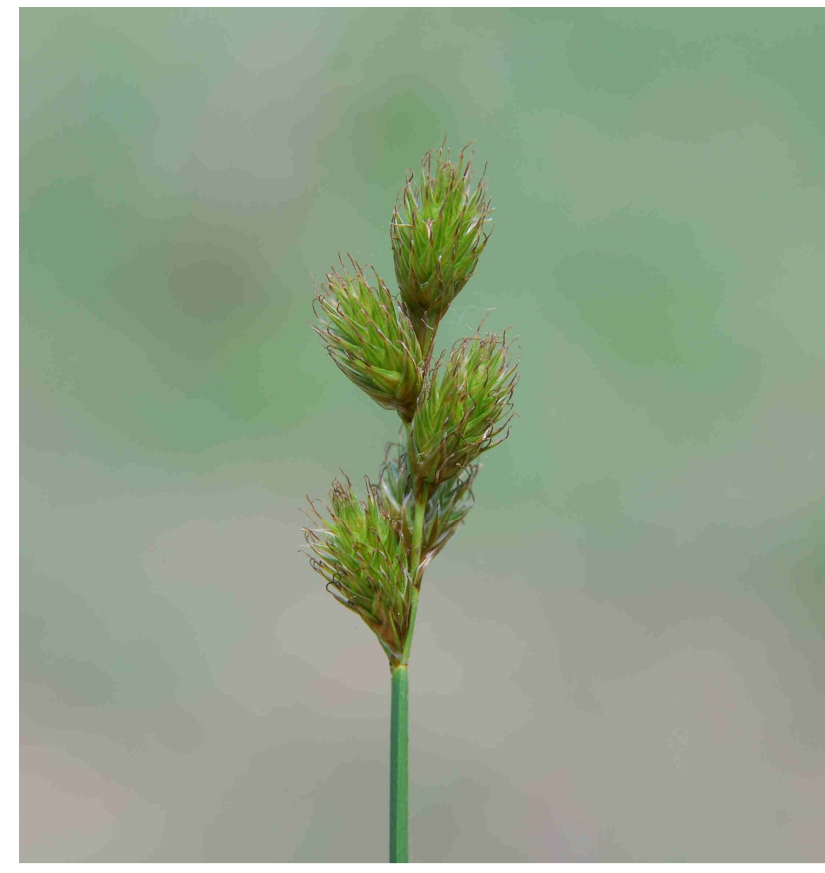

e2. ábra Carex ovalis, Nyírábrány, Keszler-tag, 2018 Fig. e2 Carex ovalis, Nyírábrány, Keszler-tag, 2018

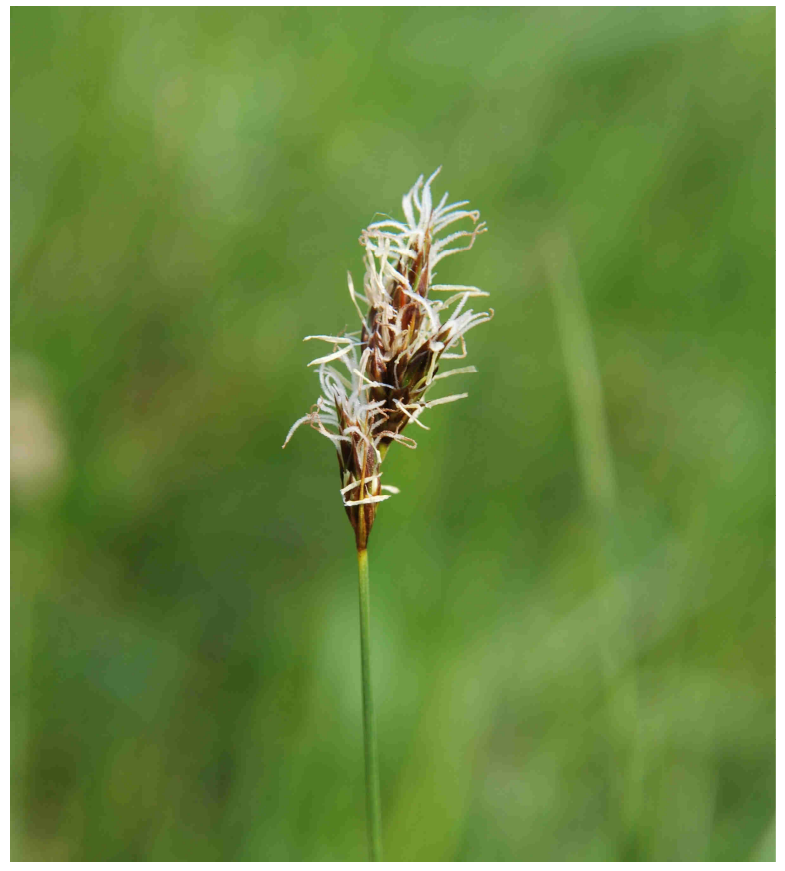

e3. ábra Carex praecox, Monostorpályi, Monostorpályi-legelő, 2010

Fig. e3 Carex praecox, Monostorpályi, Monostorpályi-legelő, 2010 


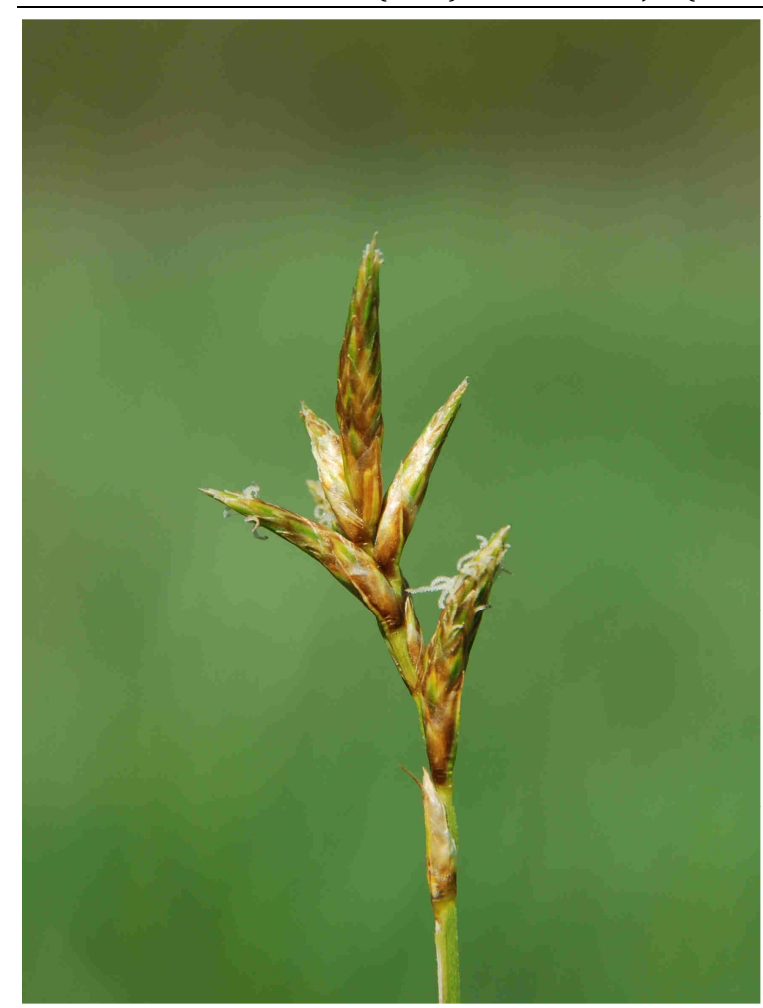

e4. ábra Carex brizoides, Debrecen, Mézeshegyi-tölgyes, 2013

Fig. e4 Carex brizoides, Debrecen, Mézeshegyi-tölgyes, 2013

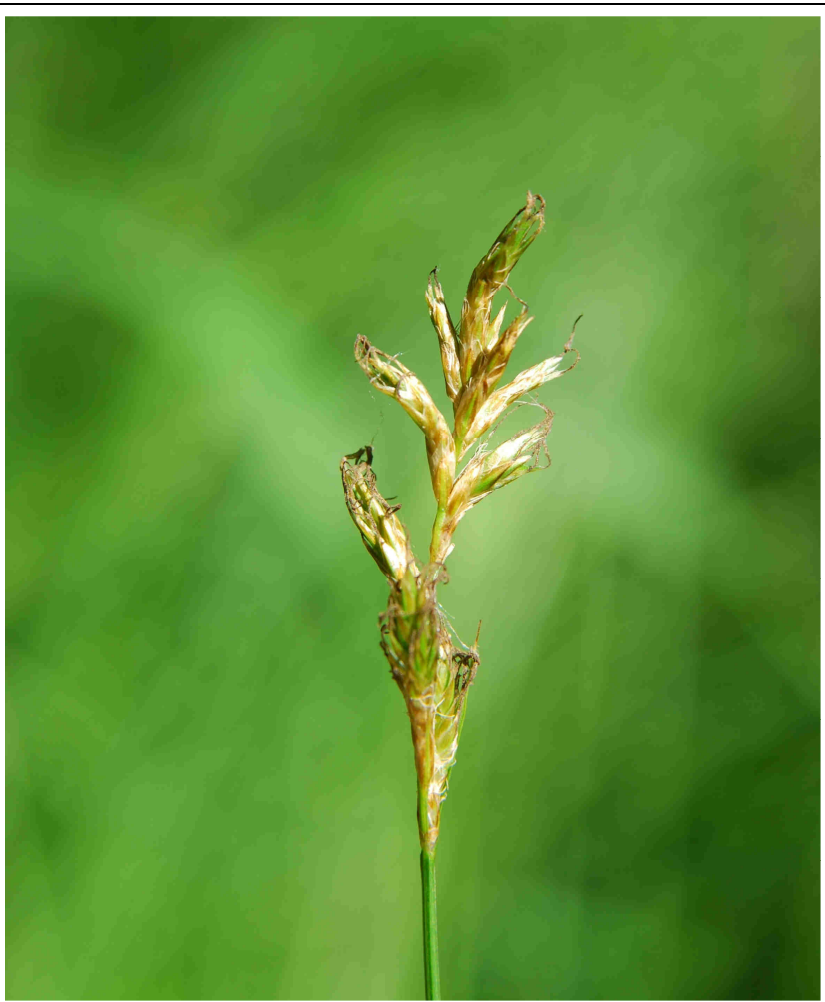

e5. ábra Carex brizoides, Nyírmártonfalva, Berek-szilas, 2021

Fig. e5 Carex brizoides, Nyírmártonfalva, Berek-szilas, 2021

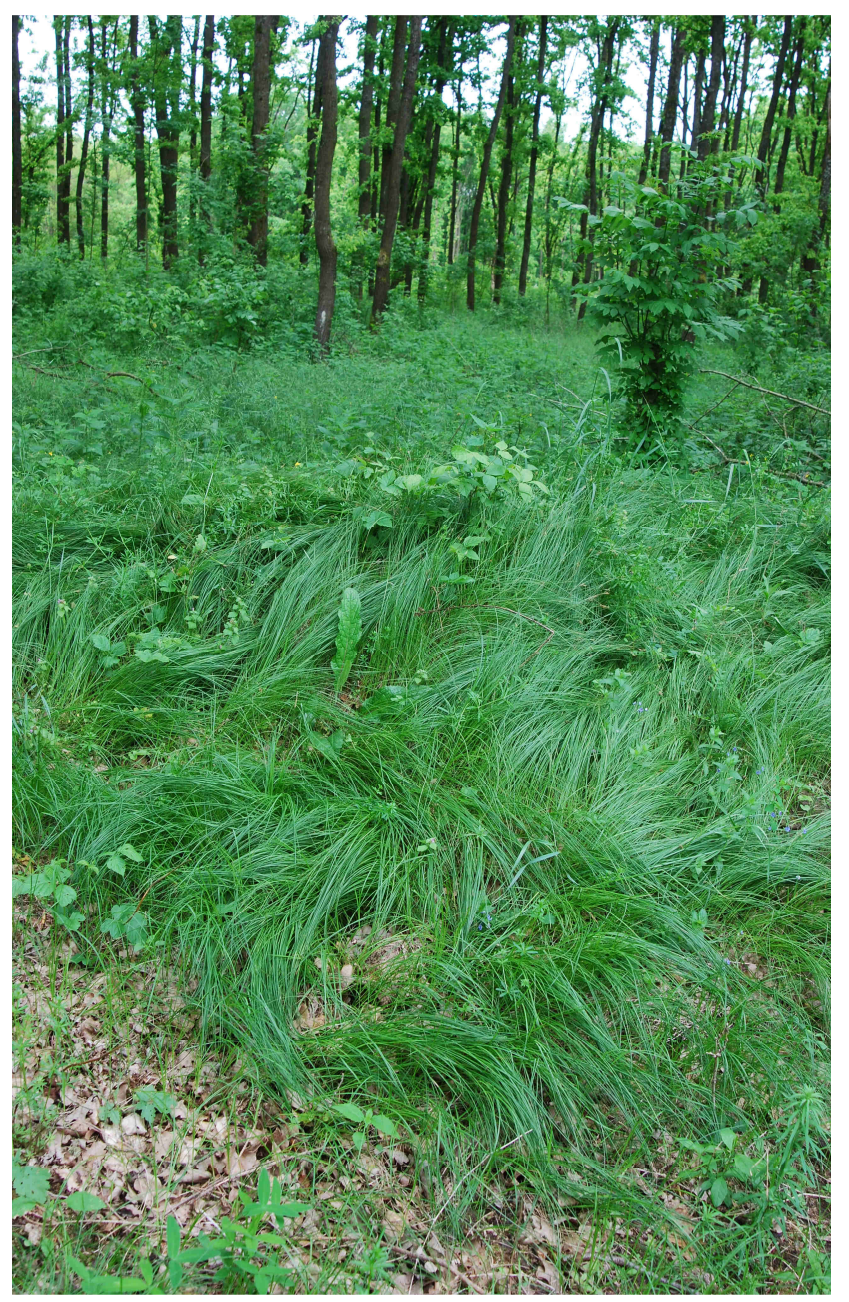

e6. ábra Carex brizoides, Bagamér, Nagy-erdő, 2021

Fig. e6 Carex brizoides, Bagamér, Nagy-erdő, 2021 


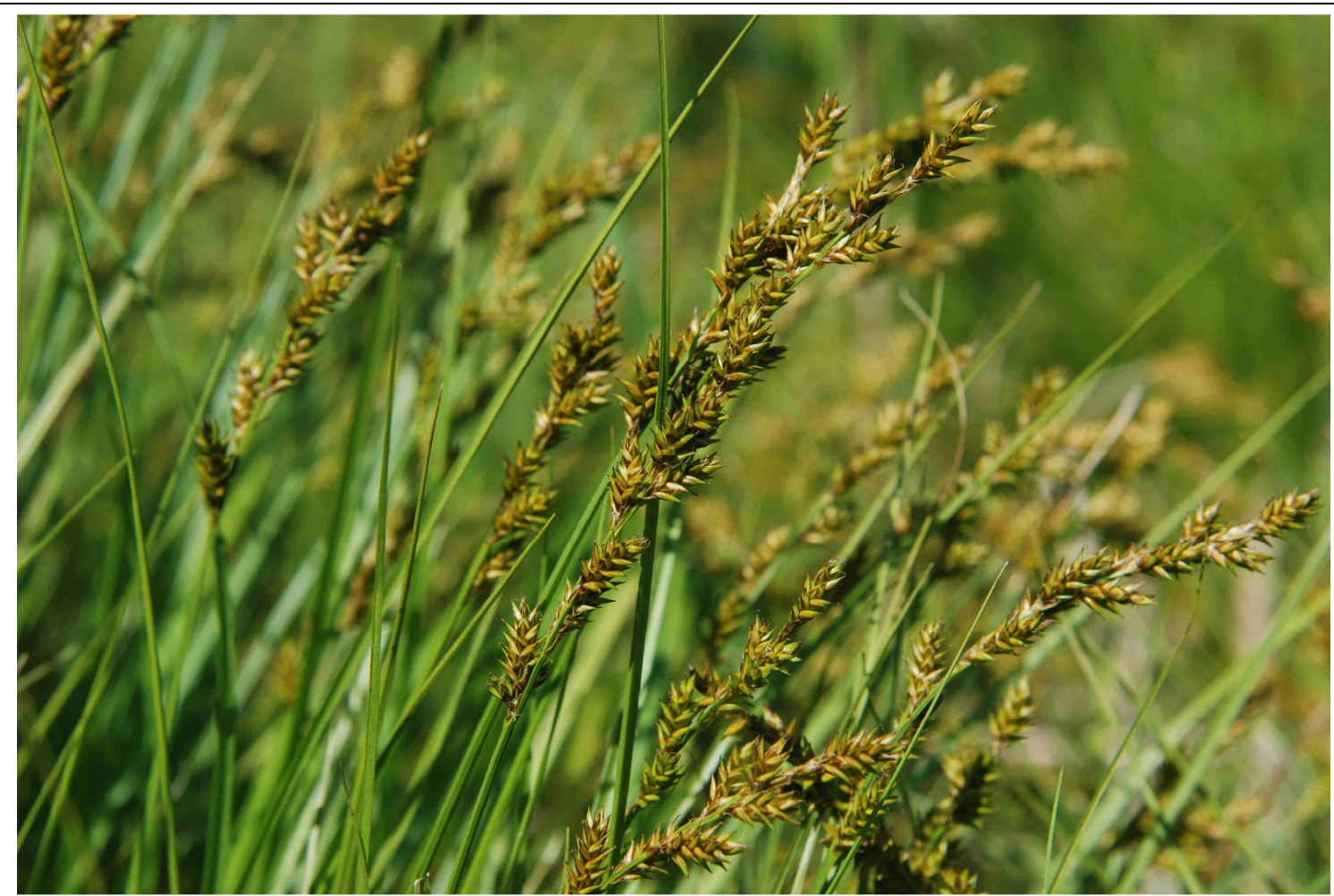

e7. ábra Carex elongata, Álmosd, Daru-láp, 2011

Fig. e7 Carex elongata, Álmosd, Daru-láp, 2011

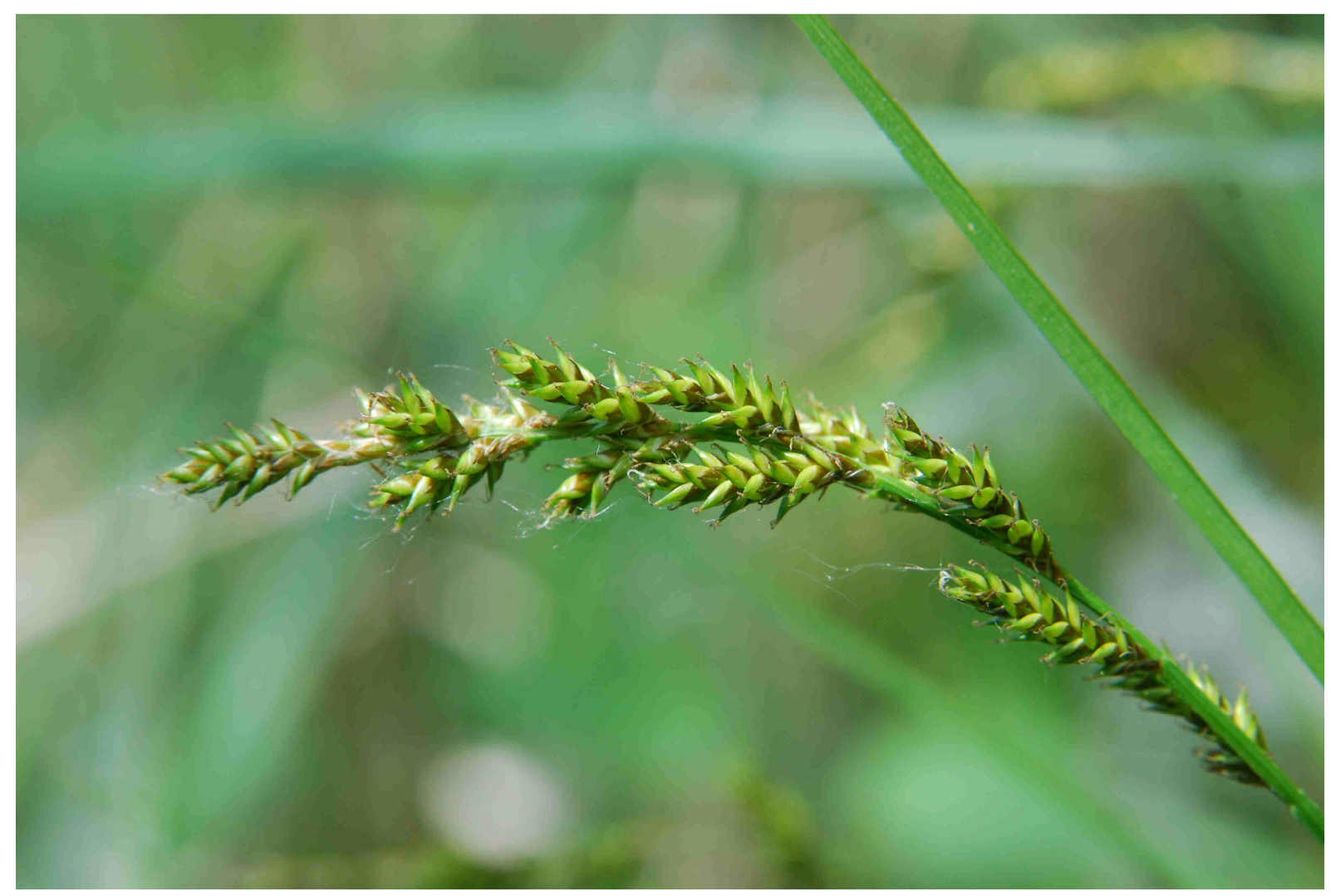

e8. ábra Carex elongata, Debrecen, Hármas-hegy alja, 2017

Fig. e8 Carex elongata, Debrecen, Hármas-hegy alja, 2017 


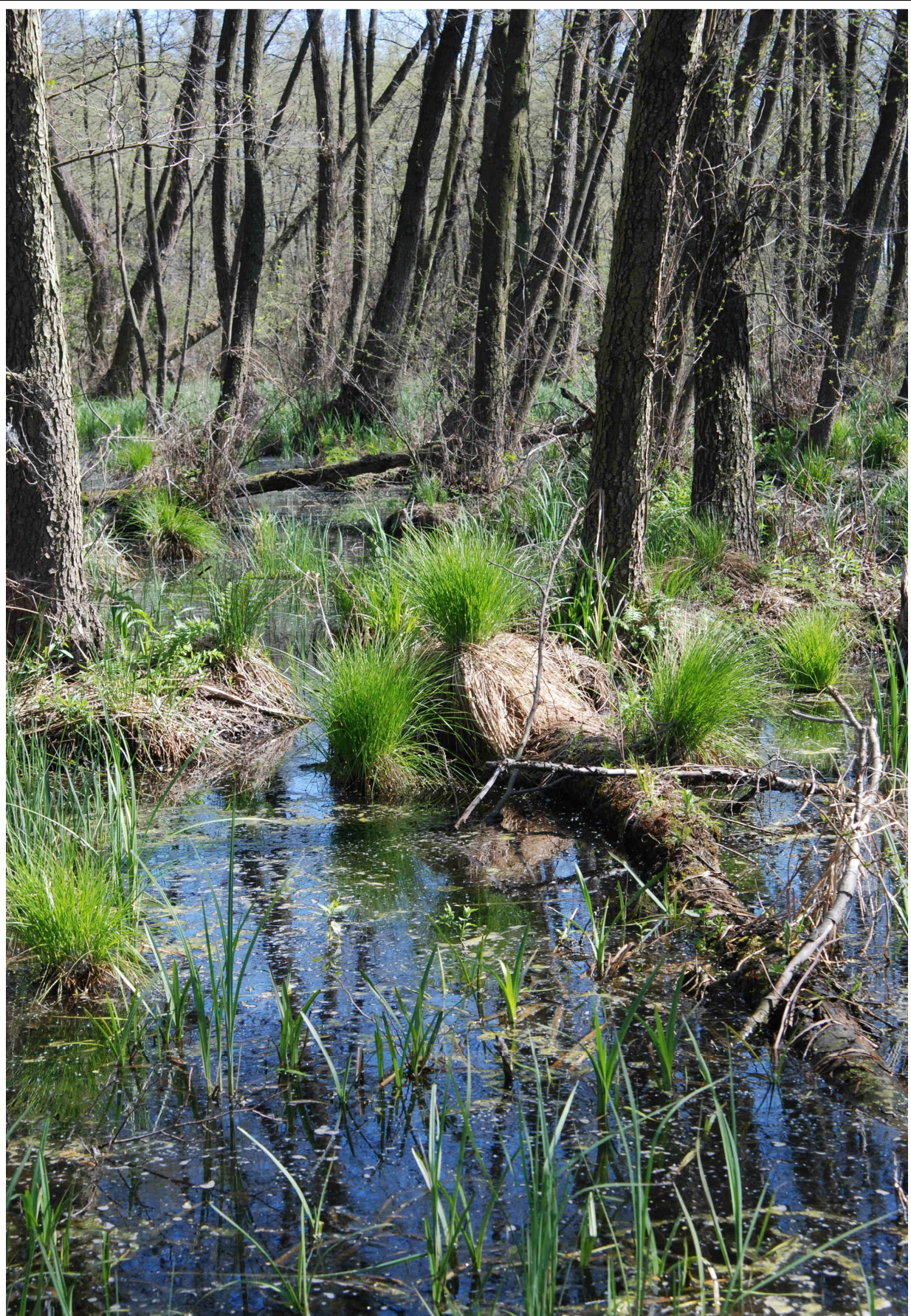

e10. ábra Carex elongata, Létavértes, Toszorka-rét, 2012

Fig. e10 Carex elongata, Létavértes, Toszorka-rét, 2012 


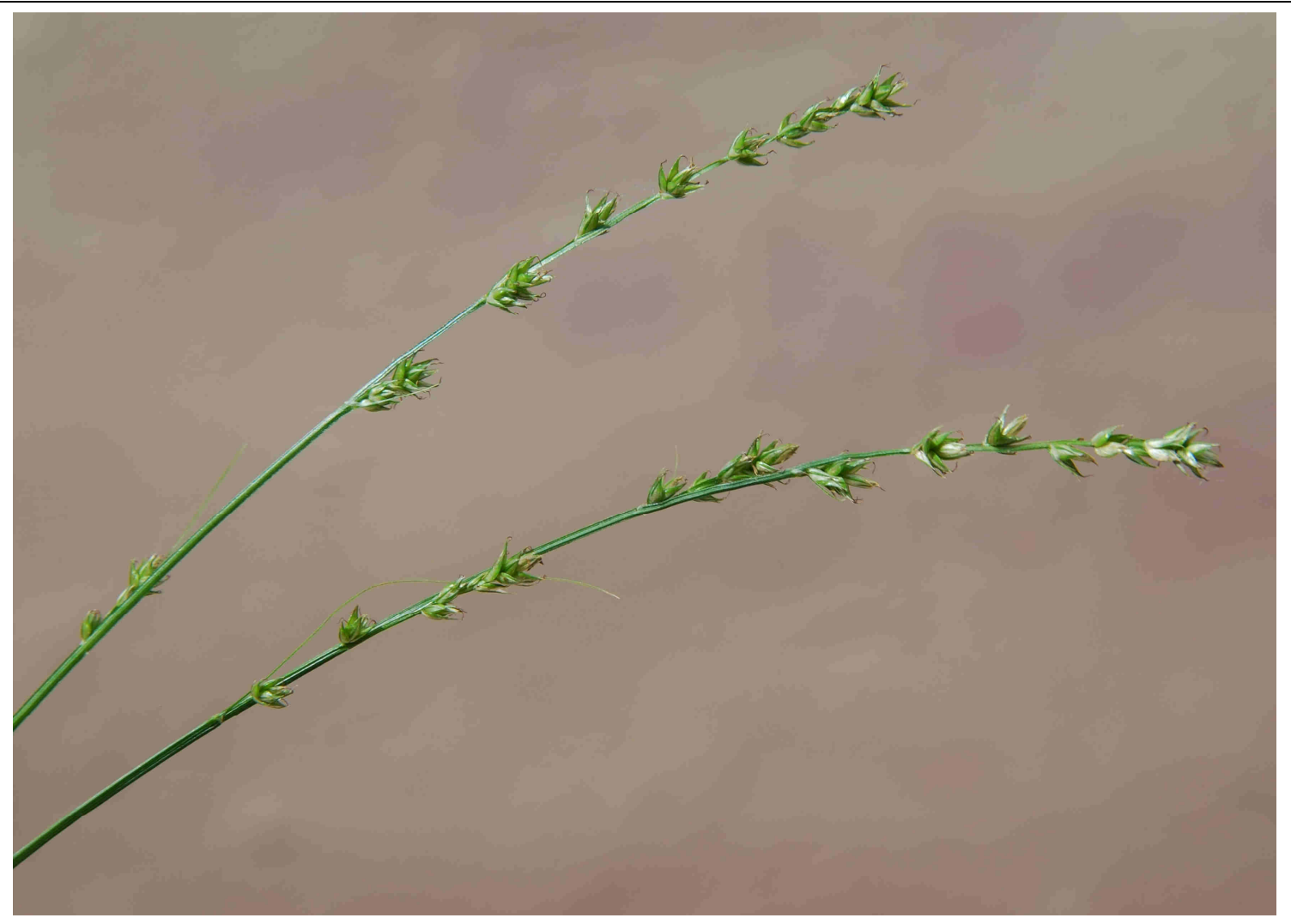

e10. ábra Carex divulsa subsp. divulsa, Debrecen-Nagycsere, Kőrises Arborétum, 2020

Fig. e10 Carex divulsa subsp. divulsa, Debrecen-Nagycsere, Kőrises Arborétum, 2020

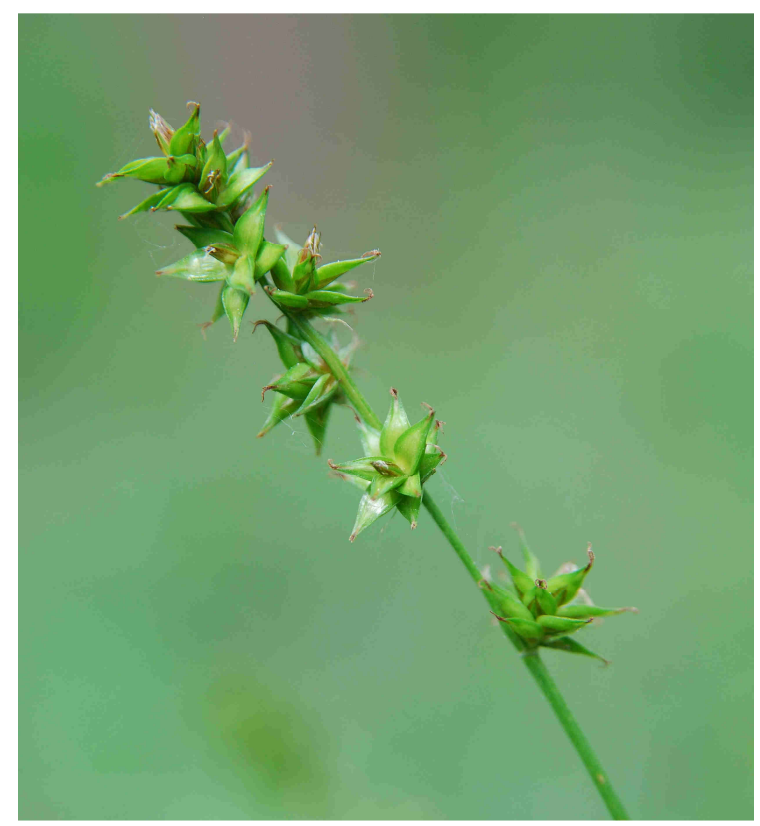

e11. ábra Carex divulsa subsp. leersii, DebrecenNagycsere, Kőrises Arborétum, 2020

Fig. e11 Carex divulsa subsp. leersii, DebrecenNagycsere, Kőrises Arborétum, 2020

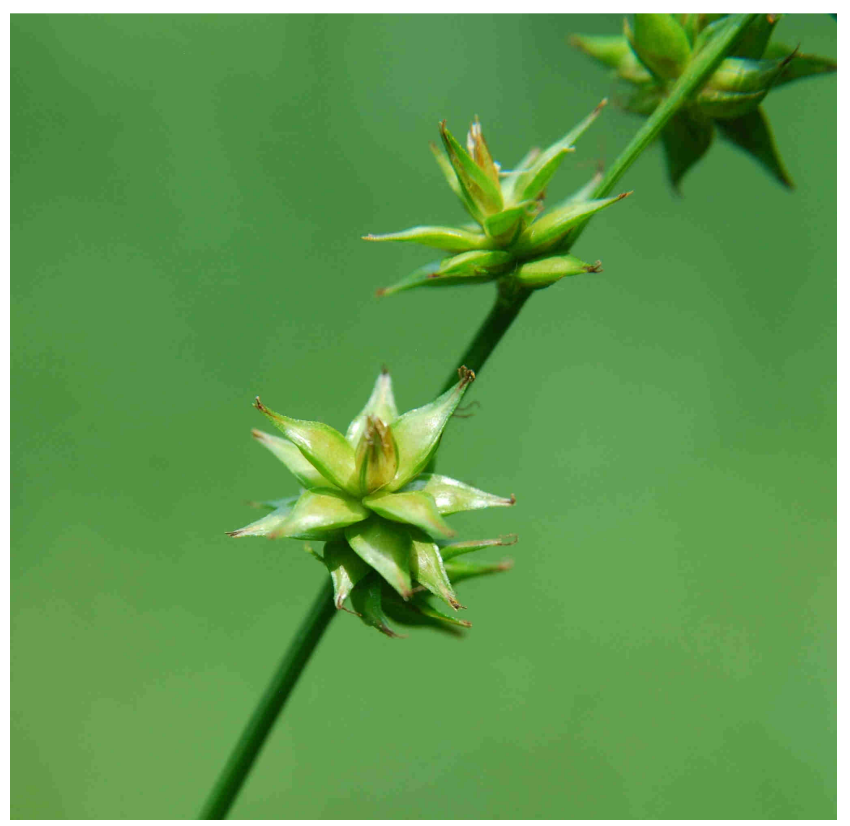

e12. ábra Carex divulsa subsp. leersii, Debrecen, Nagyerdő, 2020

Fig. e12 Carex divulsa subsp. leersii, Debrecen, Nagyerdő, 2020 


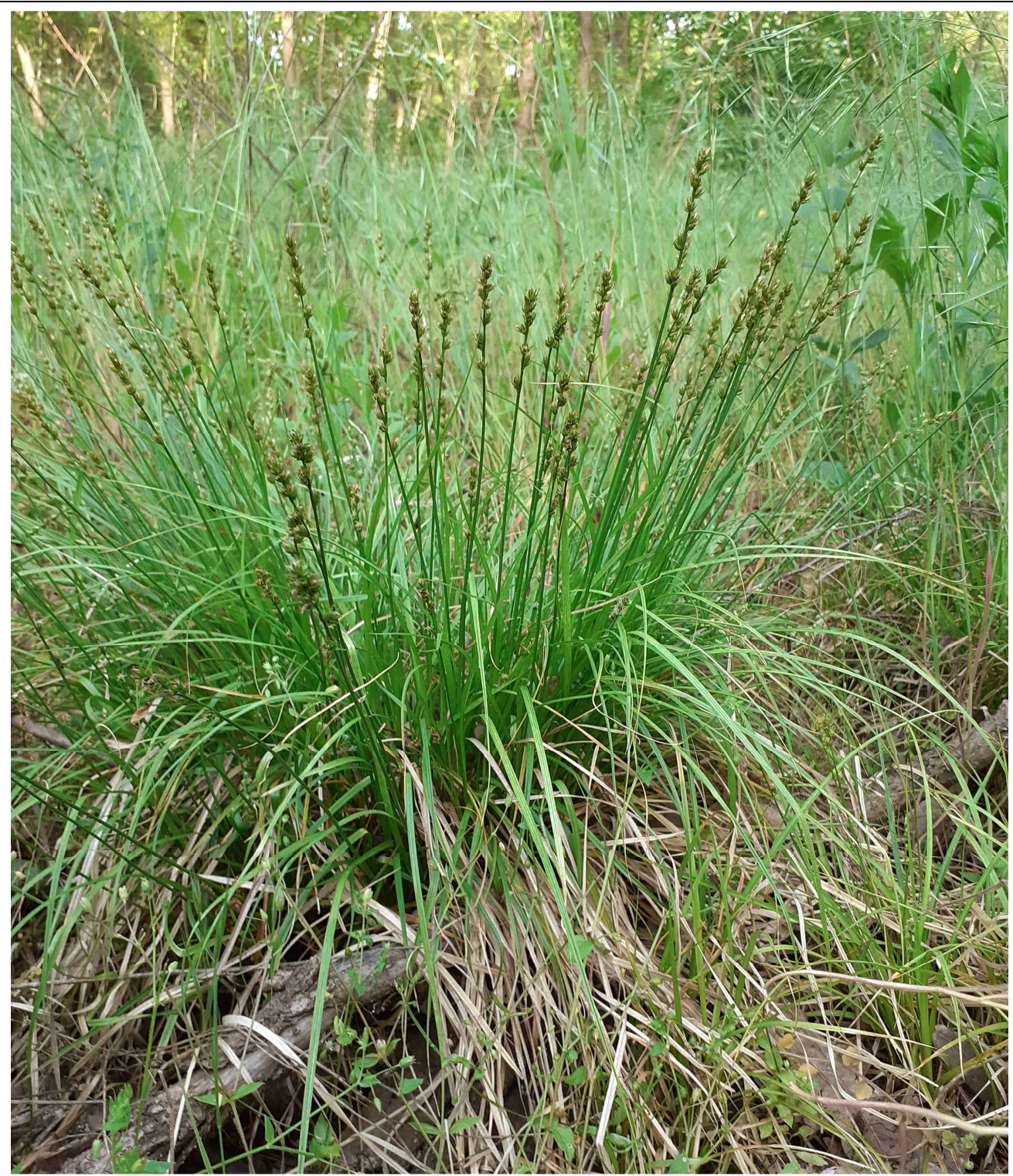

e13. ábra Carex divulsa subsp. leersii, Hajdúhadház, Csereerdő, 2020

Fig. e13 Carex divulsa subsp. leersii, Hajdúhadház, Csereerdő, 2020

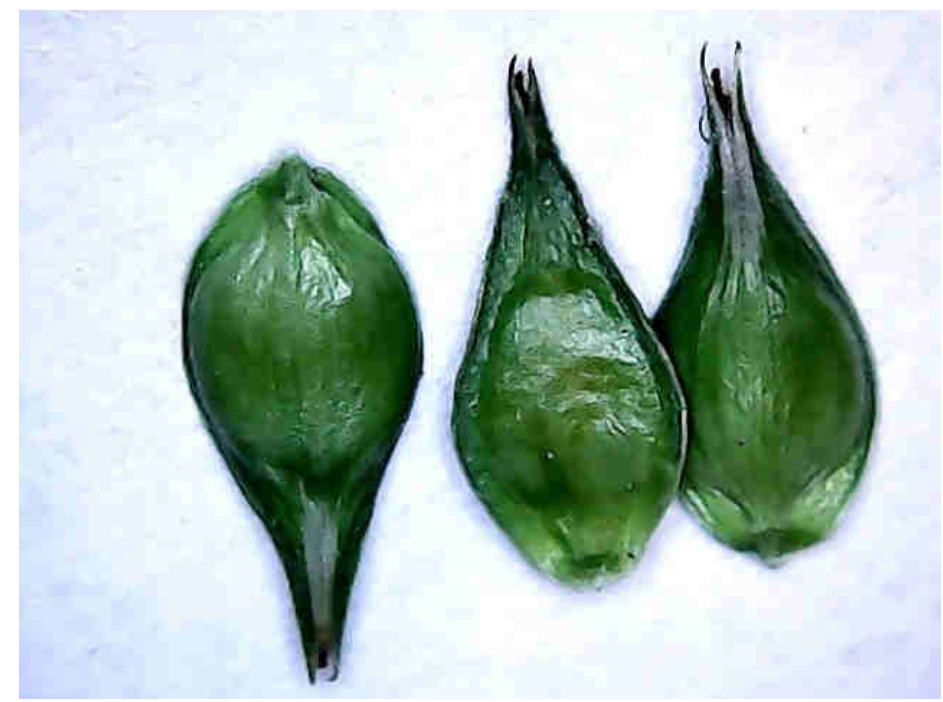

e14. ábra Carex divulsa subsp. leersii tömlőcskéi, Hajdúböszörmény, 2020

Fig. e14 Utricles of Carex divulsa subsp. leersii, Hajdúböszörmény, 2020 


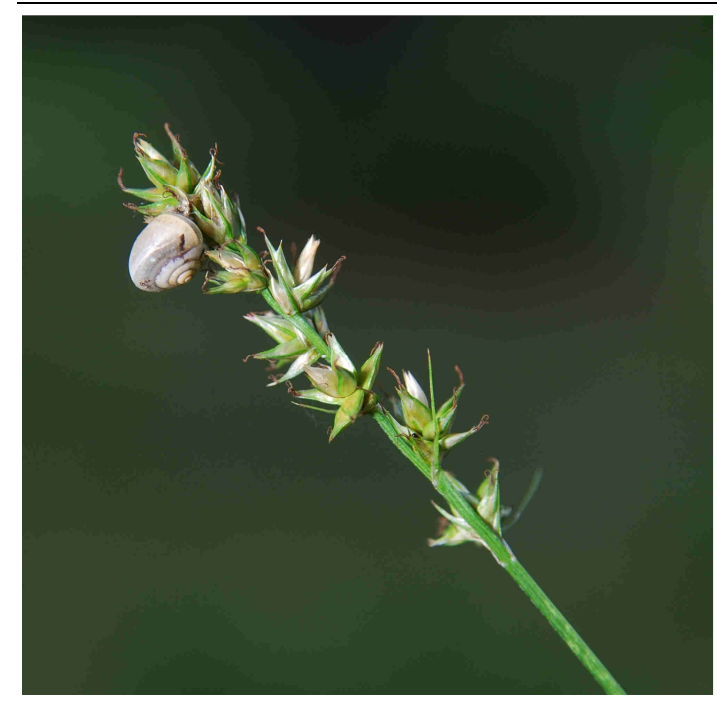

e15. ábra Carex spicata, Debrecen, Bánki-erdő, 2018

Fig. e15 Carex spicata, Debrecen, Bánki-erdő, 2018

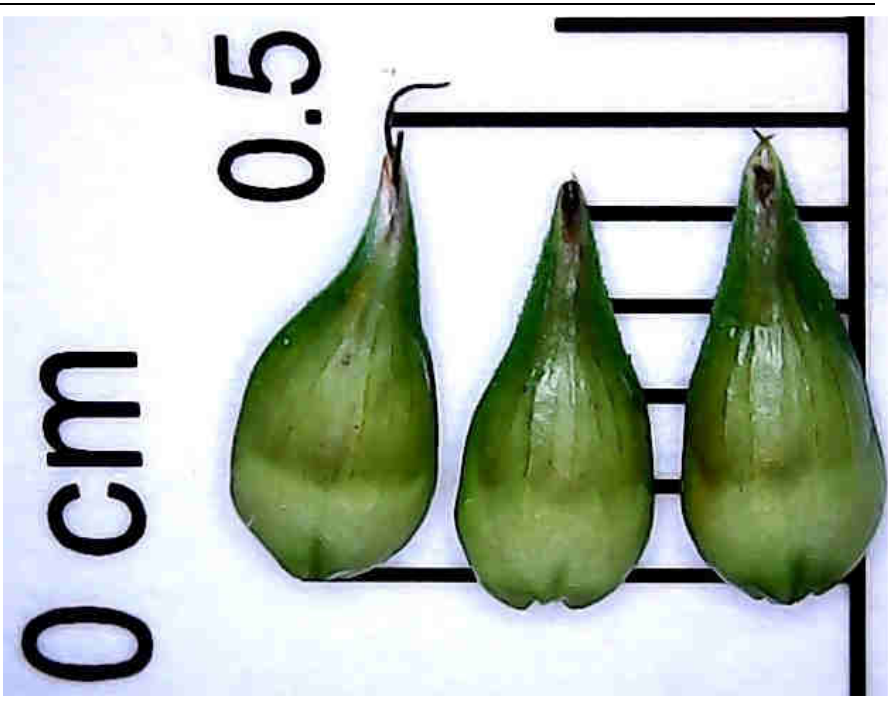

e16. ábra Carex spicata tömlőcskéi, Hajdúhadház, Csereerdő, 2020

Fig. e16 Utricles of Carex spicata, Hajdúhadház, Csereerdő, 2020

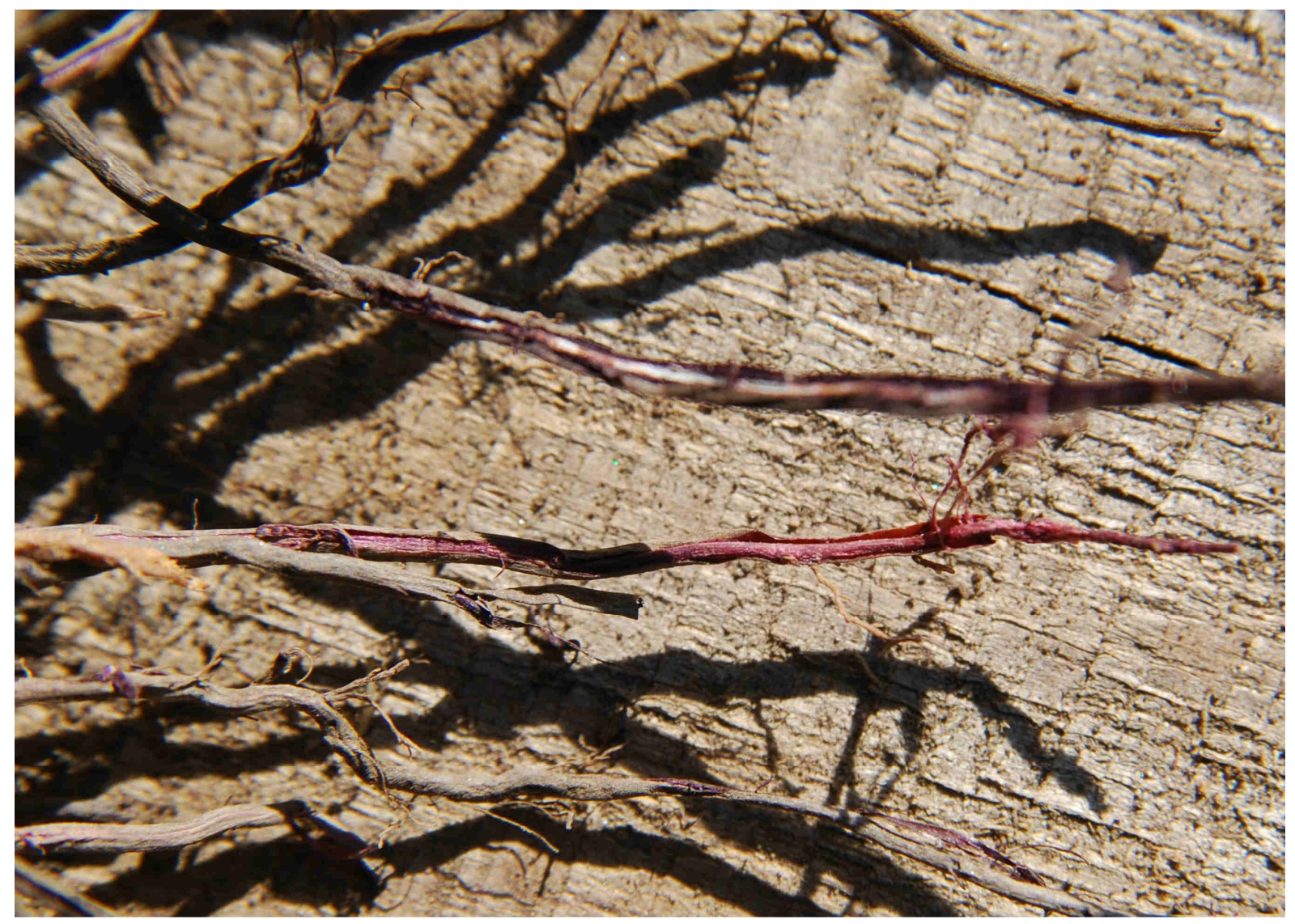

e17. ábra Carex spicata gyökere, Debrecen, Bánki-erdő, 2020

Fig. e17 Roots of Carex spicata, Debrecen, Bánki-erdő, 2020 


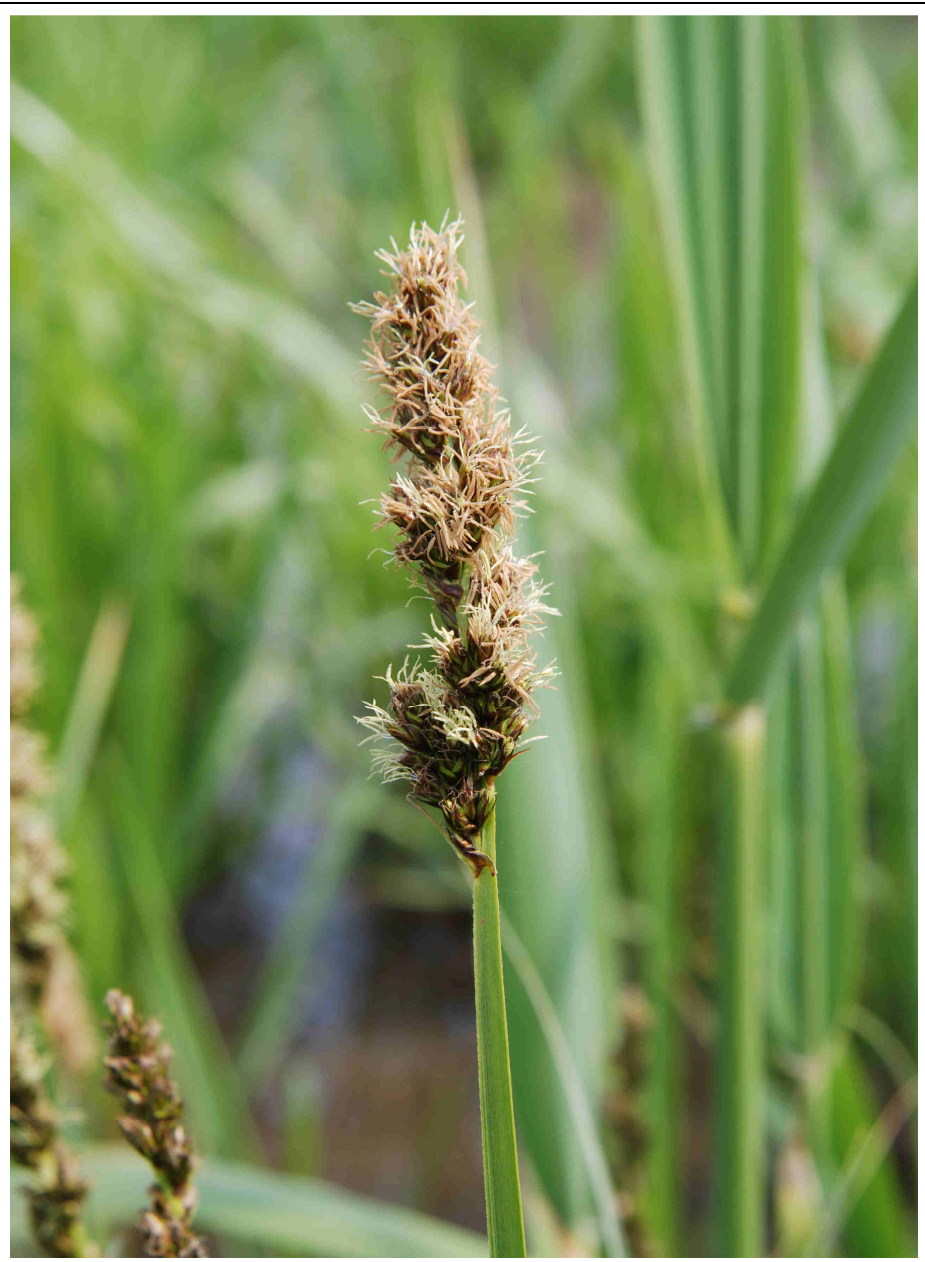

e18. ábra Carex vulpina, Hosszúpályi, Kis-Fehér-tó, 2010

Fig. e18 Carex vulpina, Hosszúpályi, Kis-Fehér-tó, 2010

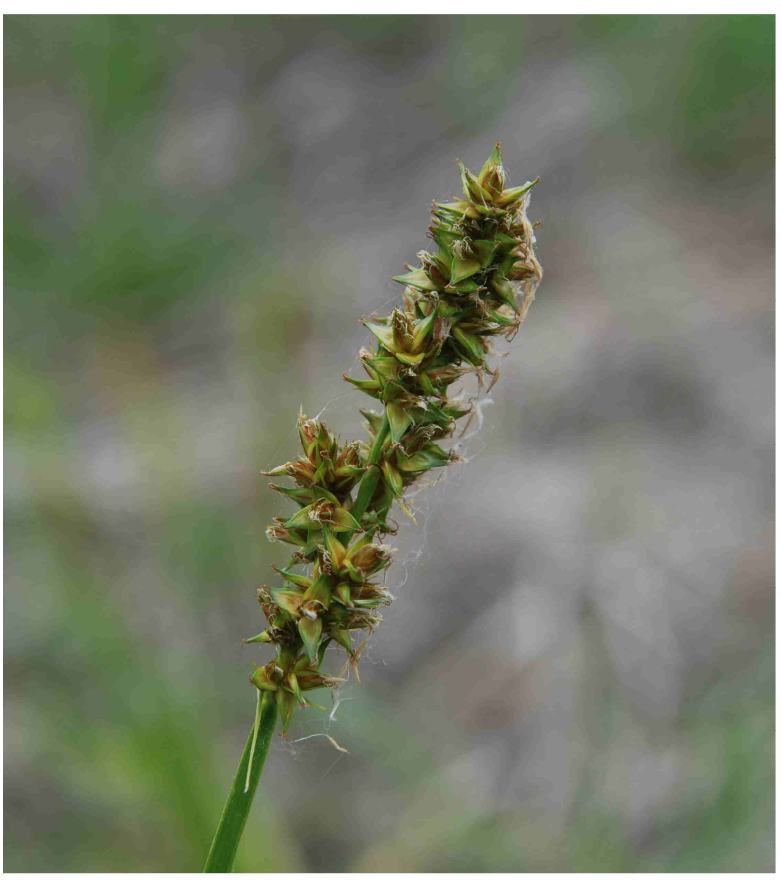

e19. ábra Carex otrubae, Debrecen, Nyárfa-lapos-dűlő, 2011

Fig. e19 Carex otrubae, Debrecen, Nyárfa-lapos-dűlő, 2011

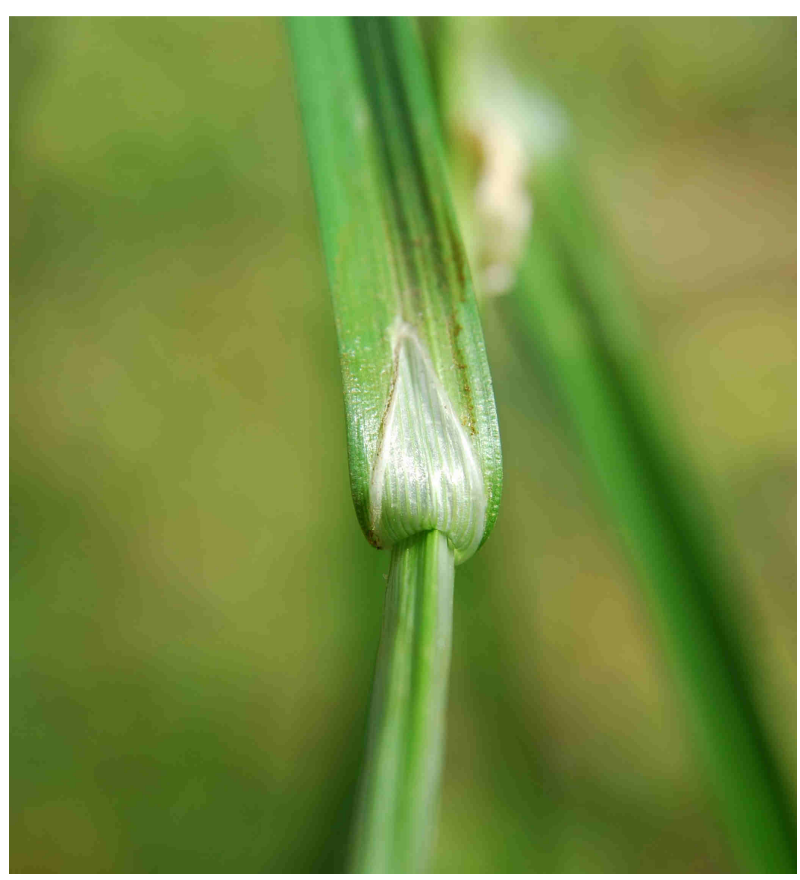

e20. ábra Carex otrubae, Debrecen-Nagycsere, Kőrises Arborétum, 2019

Fig. e20 Carex otrubae, Debrecen-Nagycsere, Kőrises Arborétum, 2019 


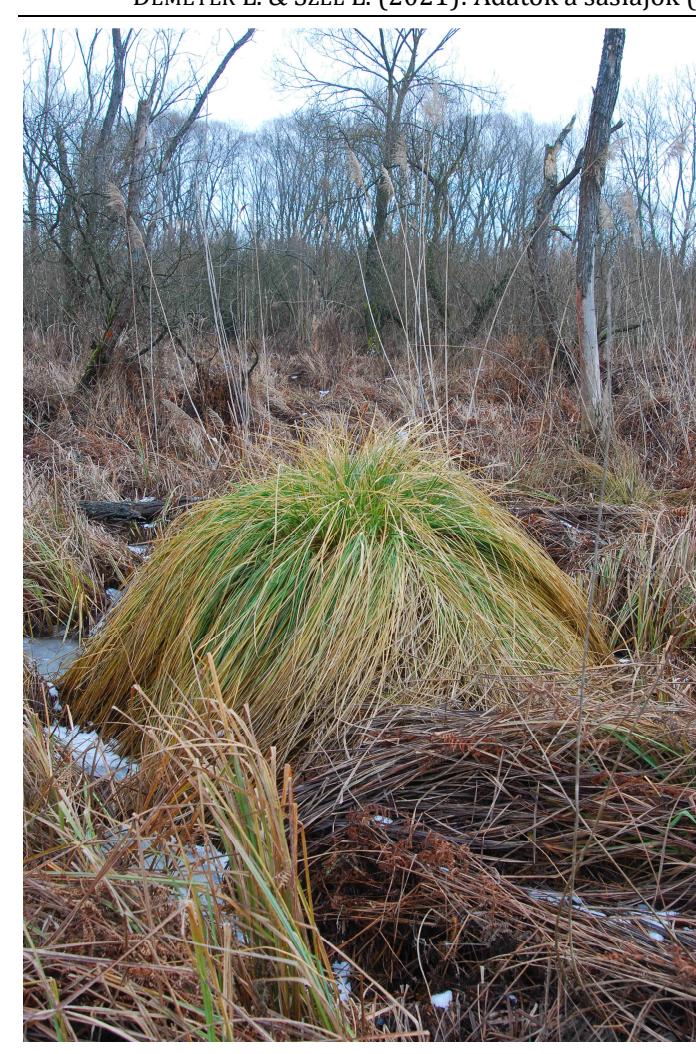

e21. ábra Carex paniculata, Kokad, Daru-láp, 2009 Fig. e21 Carex paniculata, Kokad, Daru-láp, 2009

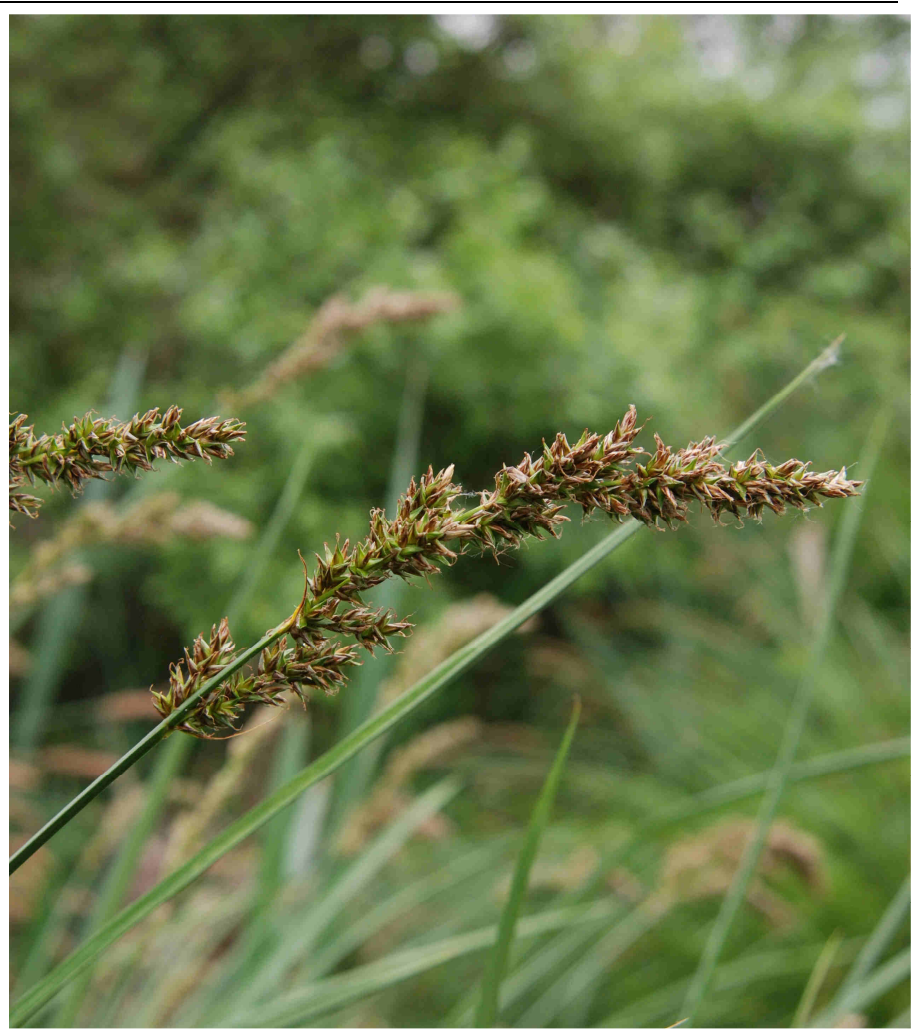

e22. ábra Carex paniculata, Kokad, Álmosd-Kokadi-tározó, 2010 Fig. e22 Carex paniculata, Kokad, Álmosd-Kokadi-tározó, 2010

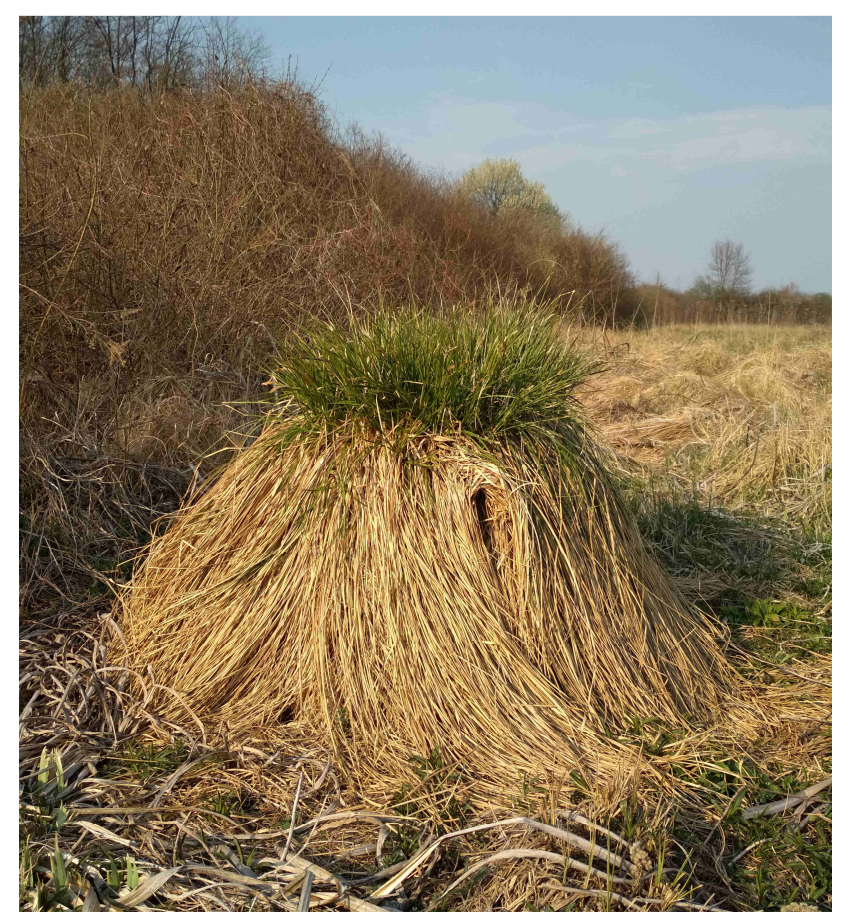

e23. ábra Carex paniculata, Bagamér, Fehérföld-sziget, 2019 Fig. e23 Carex paniculata, Bagamér, Fehérföld-sziget, 2019

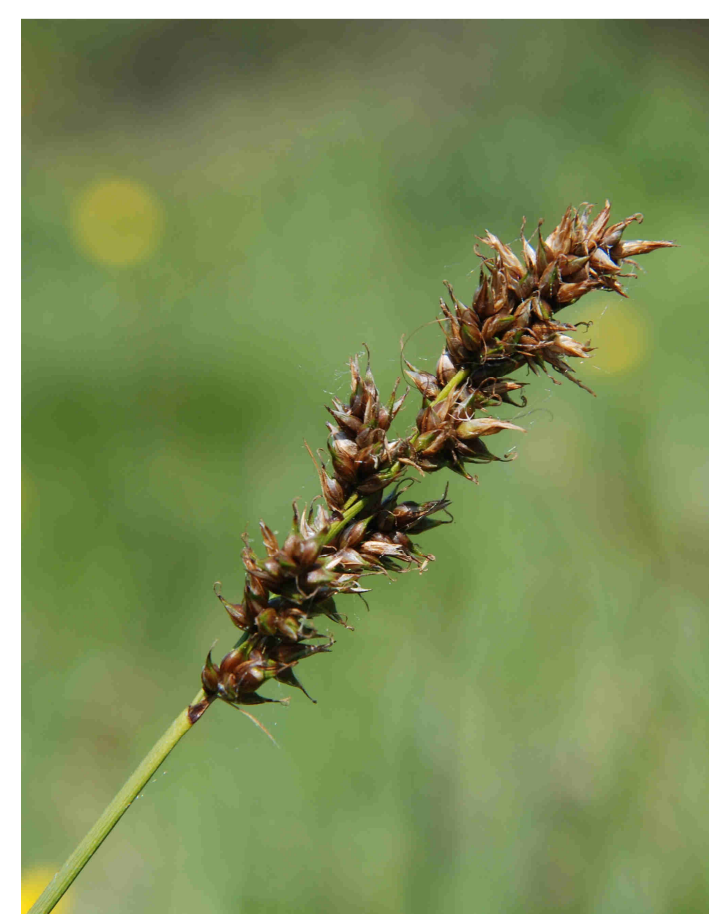

e24. ábra Carex appropinquata, Nyírábrány, Teleki-legelö, 2011

Fig. e24 Carex appropinquata, Nyírábrány, Teleki-legelő, 2011 


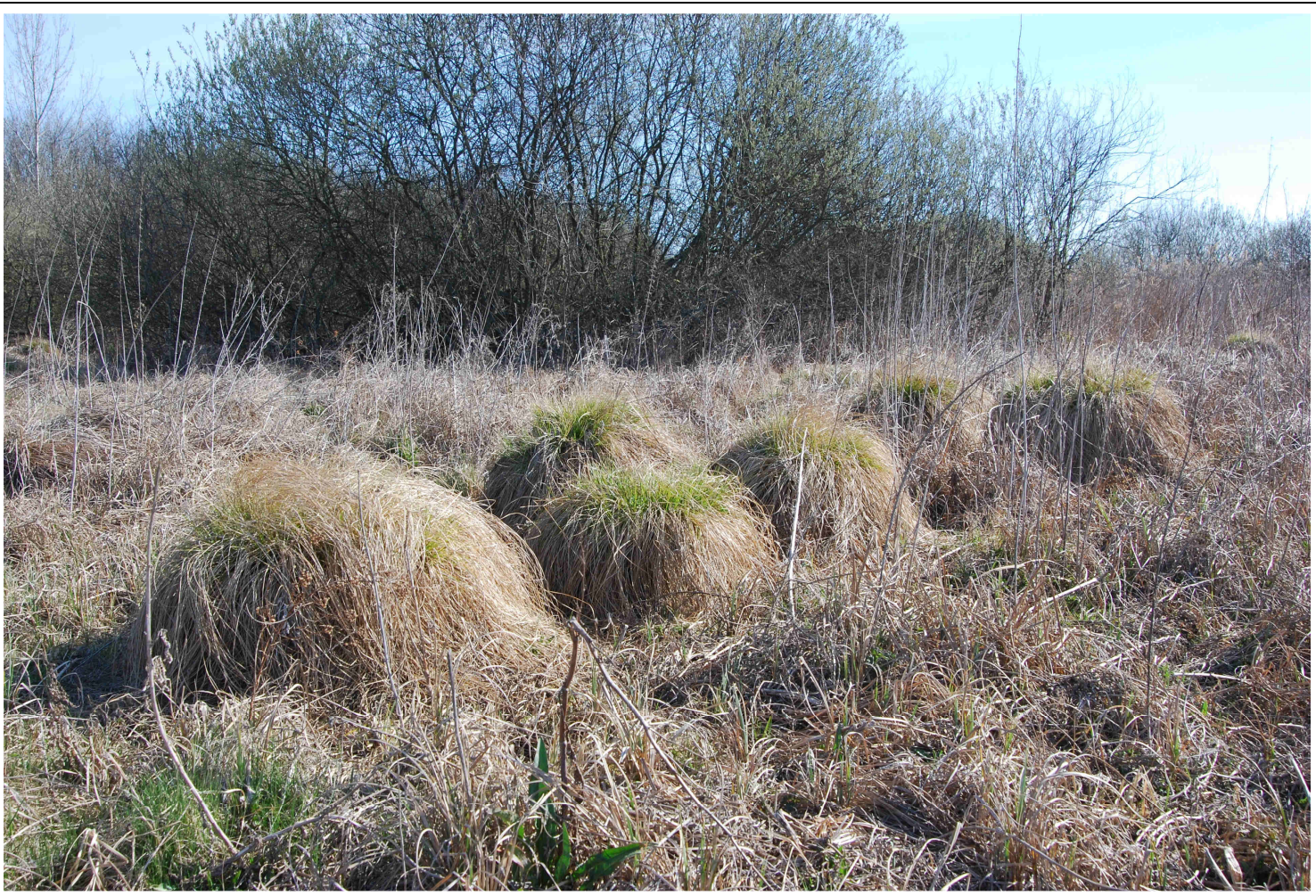

e25. ábra Carex appropinquata, Nyíracsád, Rikács, 2015

Fig. e25 Carex appropinquata, Nyíracsád, Rikács, 2015

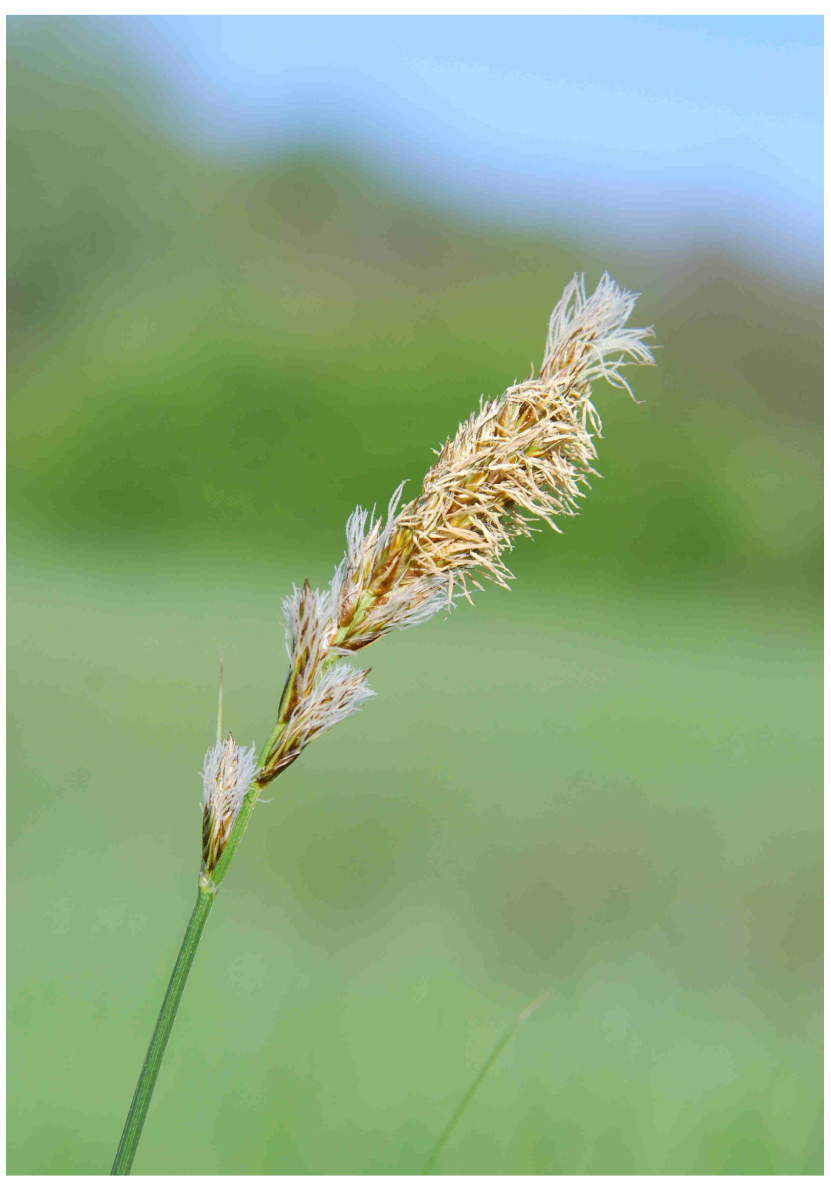

e26. ábra Carex disticha, Debrecen-Nagycsere, 2018

Fig. e26 Carex disticha, Debrecen-Nagycsere, 2018 


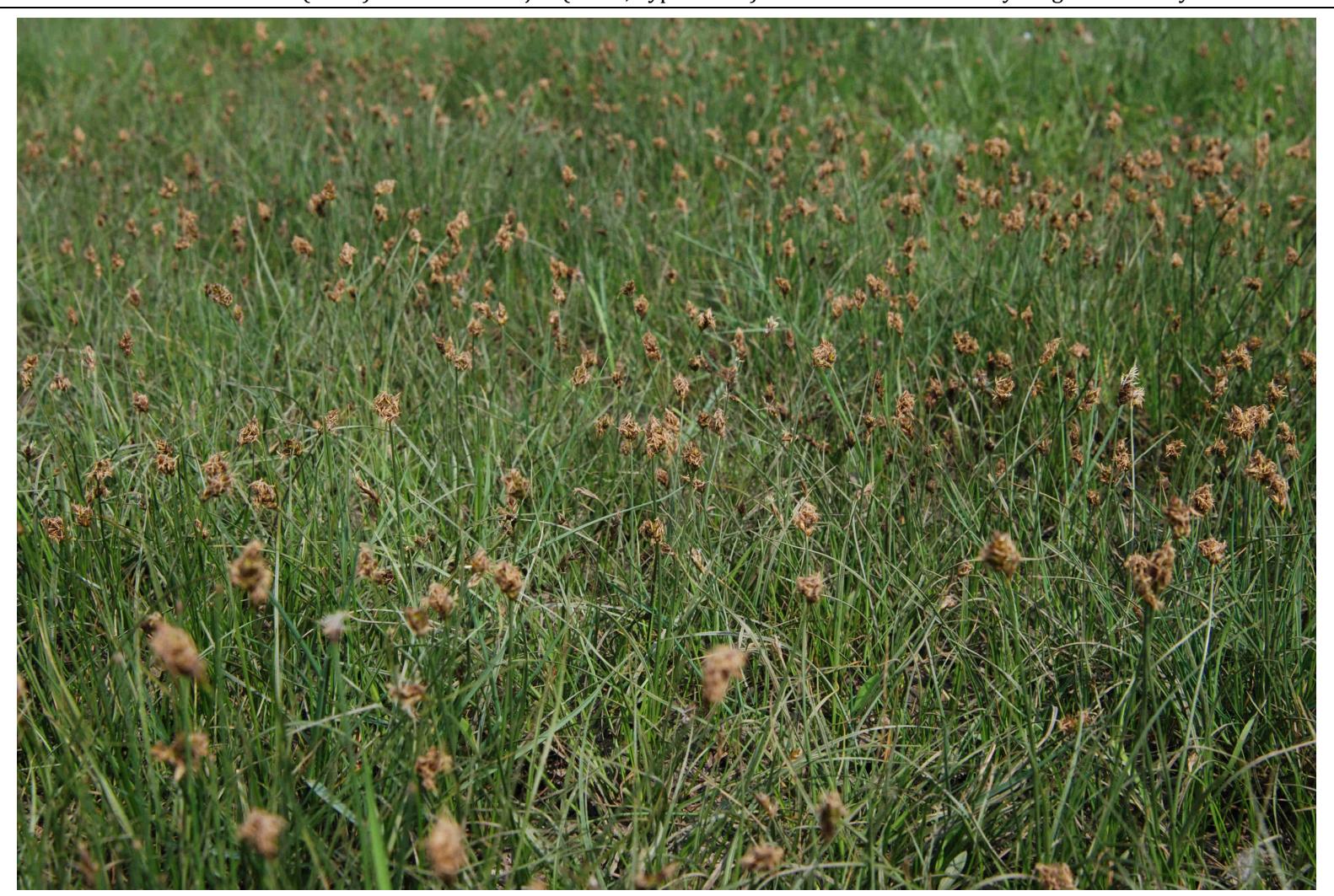

e27. ábra Carex stenophylla, Hosszúpályi, Fehértói-tározó, 2010

Fig. e27 Carex stenophylla, Hosszúpályi, Fehértói-tározó, 2010

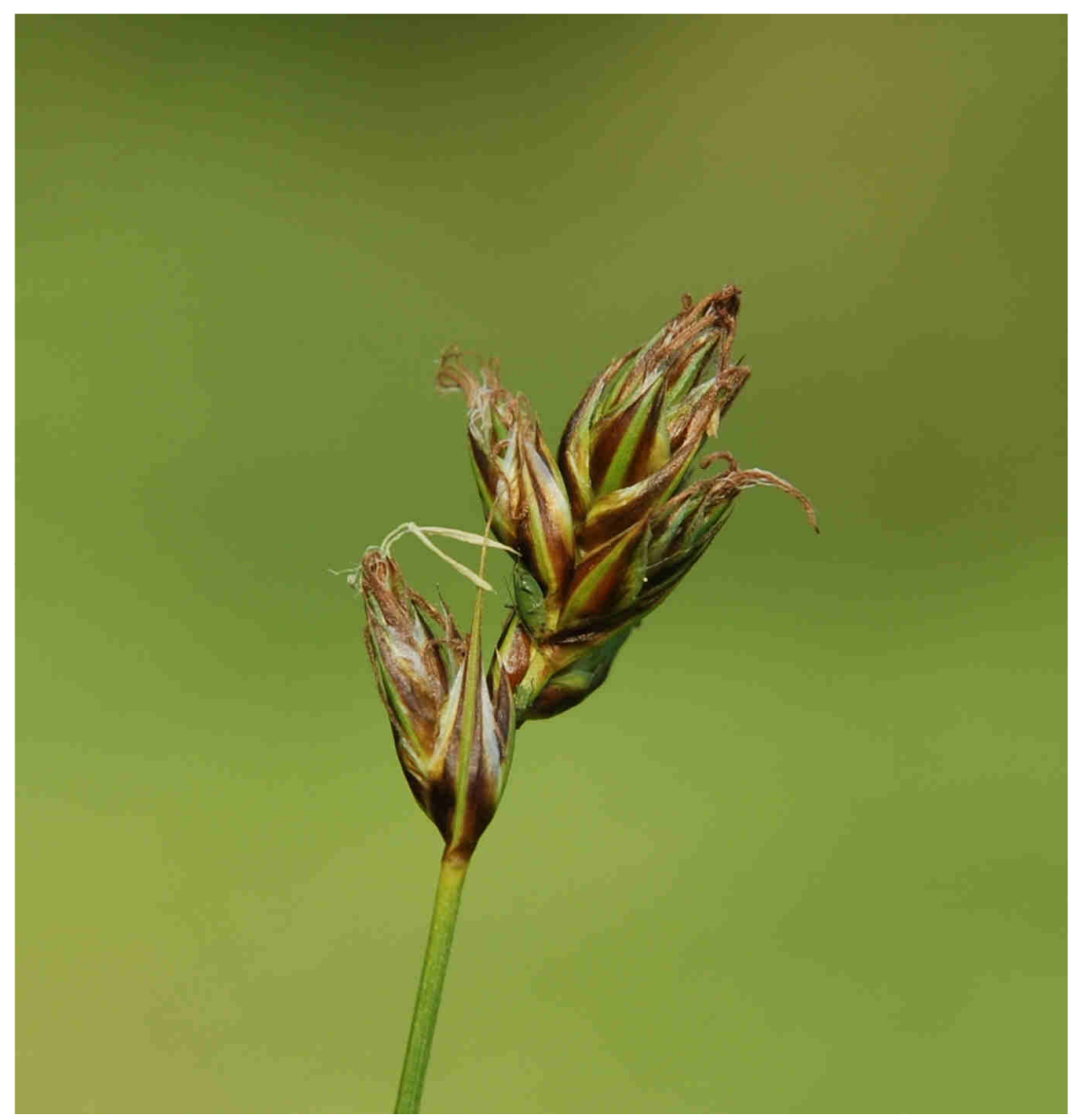

e28. ábra Carex divisa, Debrecen, Bellegelő, 2013

Fig. e28 Carex divisa, Debrecen, Bellegelő, 2013 


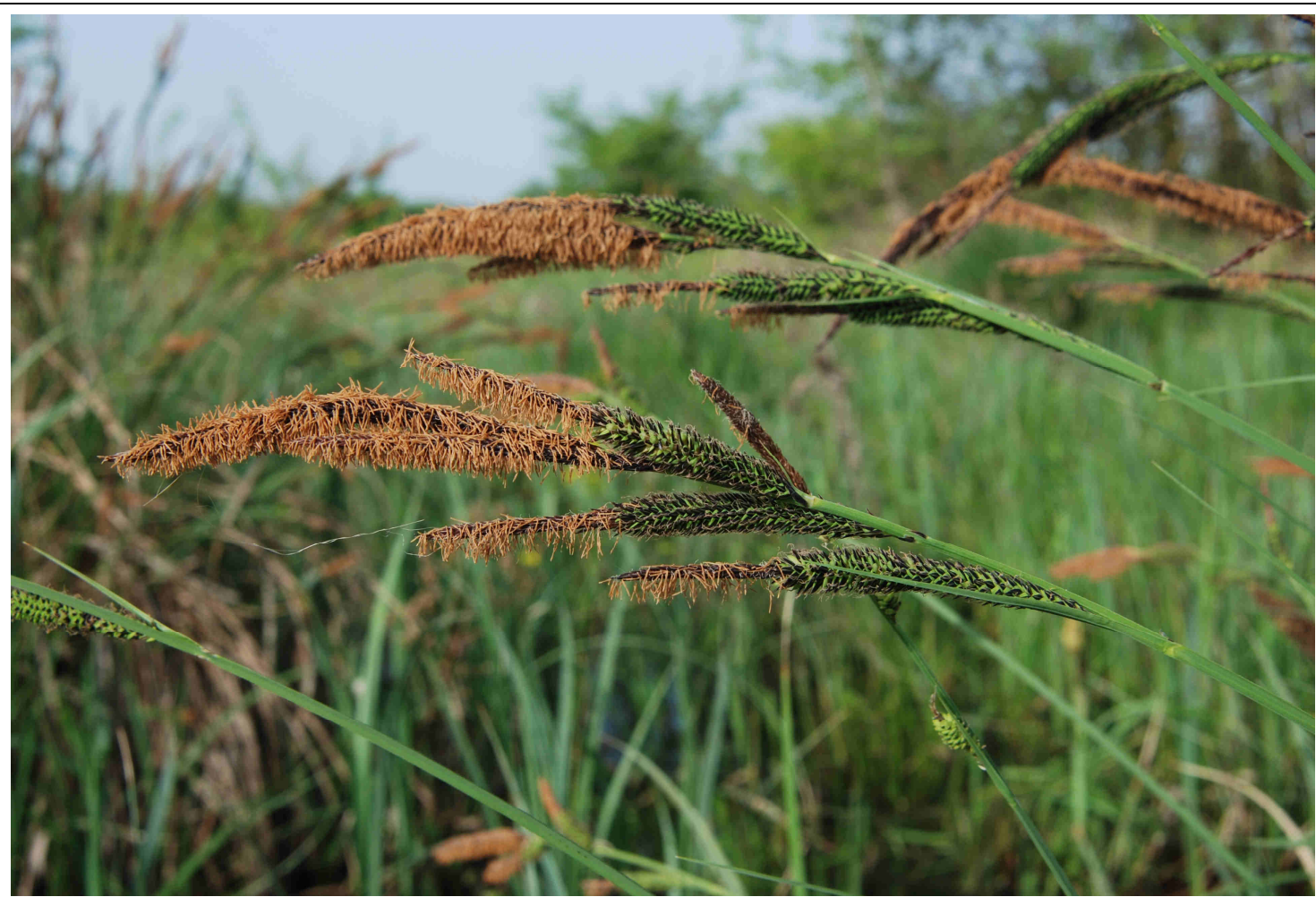

e29. ábra Carex elata, Hajdúsámson, Martinkai-legelő, 2013

Fig. e29 Carex elata, Hajdúsámson, Martinkai-legelő, 2013

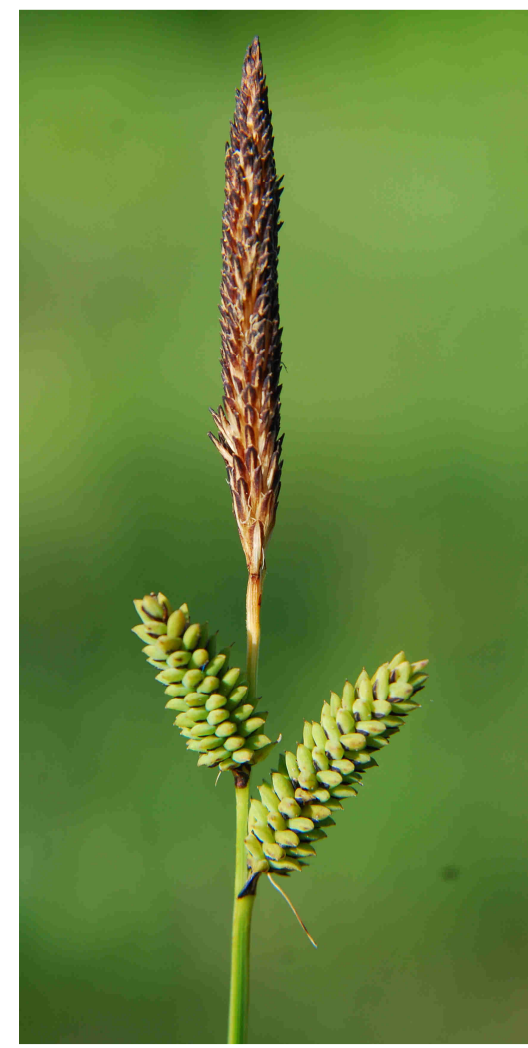

e30. ábra Carex cespitosa, Debrecen, Halápi-erdő, 2009

Fig. e30 Carex cespitosa, Debrecen, Halápi-erdo, 2009

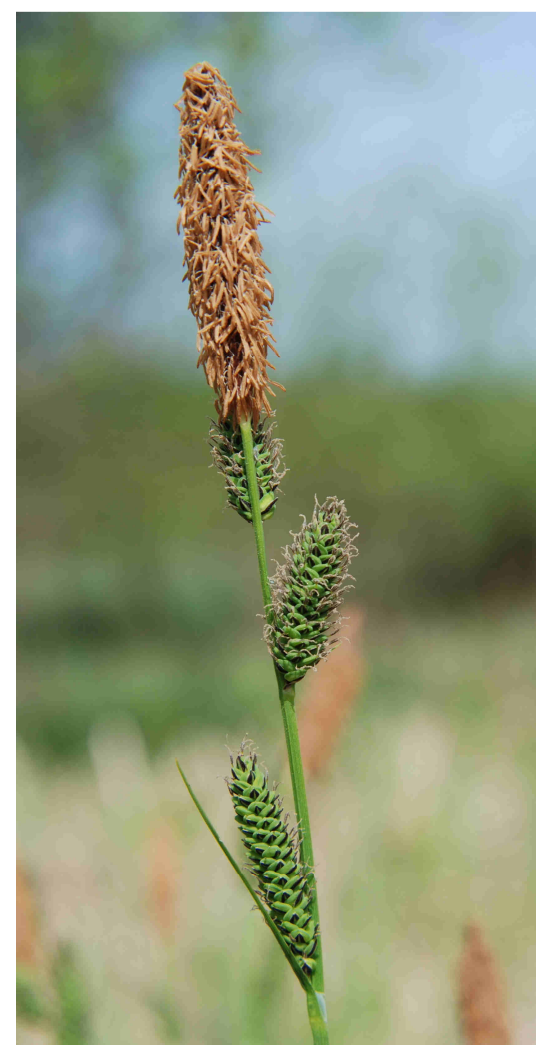

e31. ábra Carex cespitosa,

Nyírmártonfalva, Lapos-dűlő, 2013

Fig. e31 Carex cespitosa,

Nyírmártonfalva, Lapos-dűlő, 2013

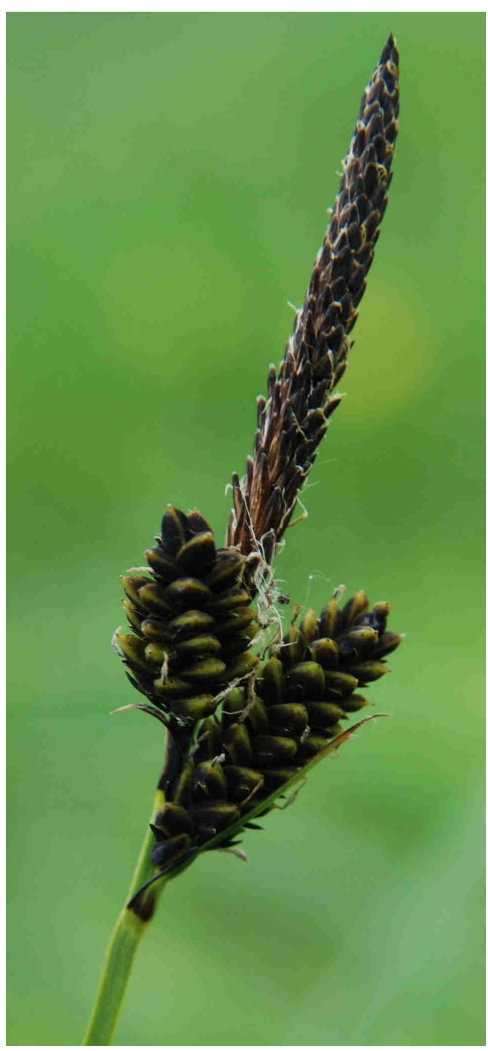

e32. ábra Carex cespitosa, feketés színezetű példány, Debrecen,

Halápi-erdő, 2014

Fig. e32 Black-coloured specimen of Carex cespitosa, Debrecen, Halápi-erdő, 2014 


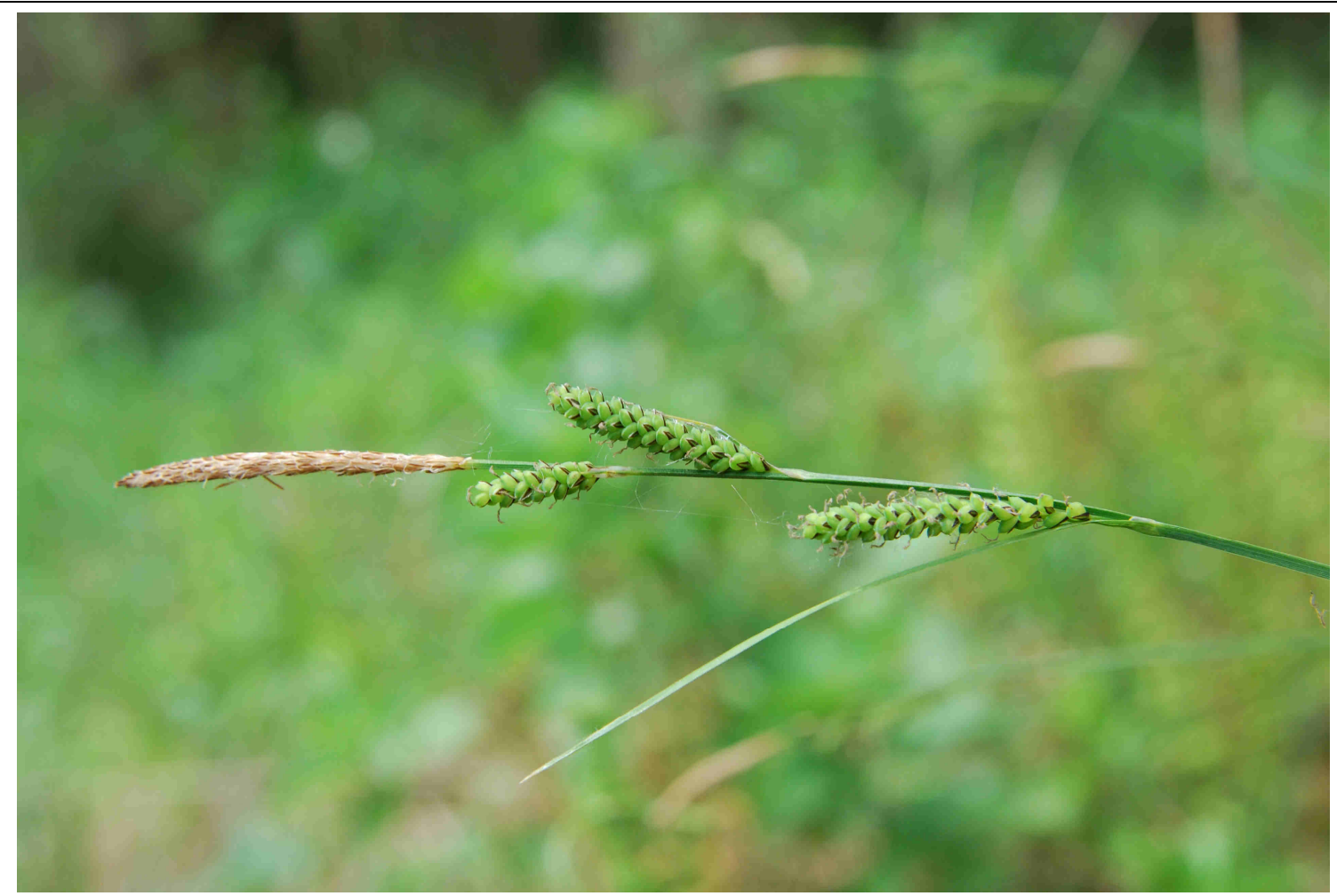

e33. ábra Carex cespitosa, Debrecen, Hármas-hegy alja, 2017

Fig. e33 Carex cespitosa, Debrecen, Hármas-hegy alja, 2017

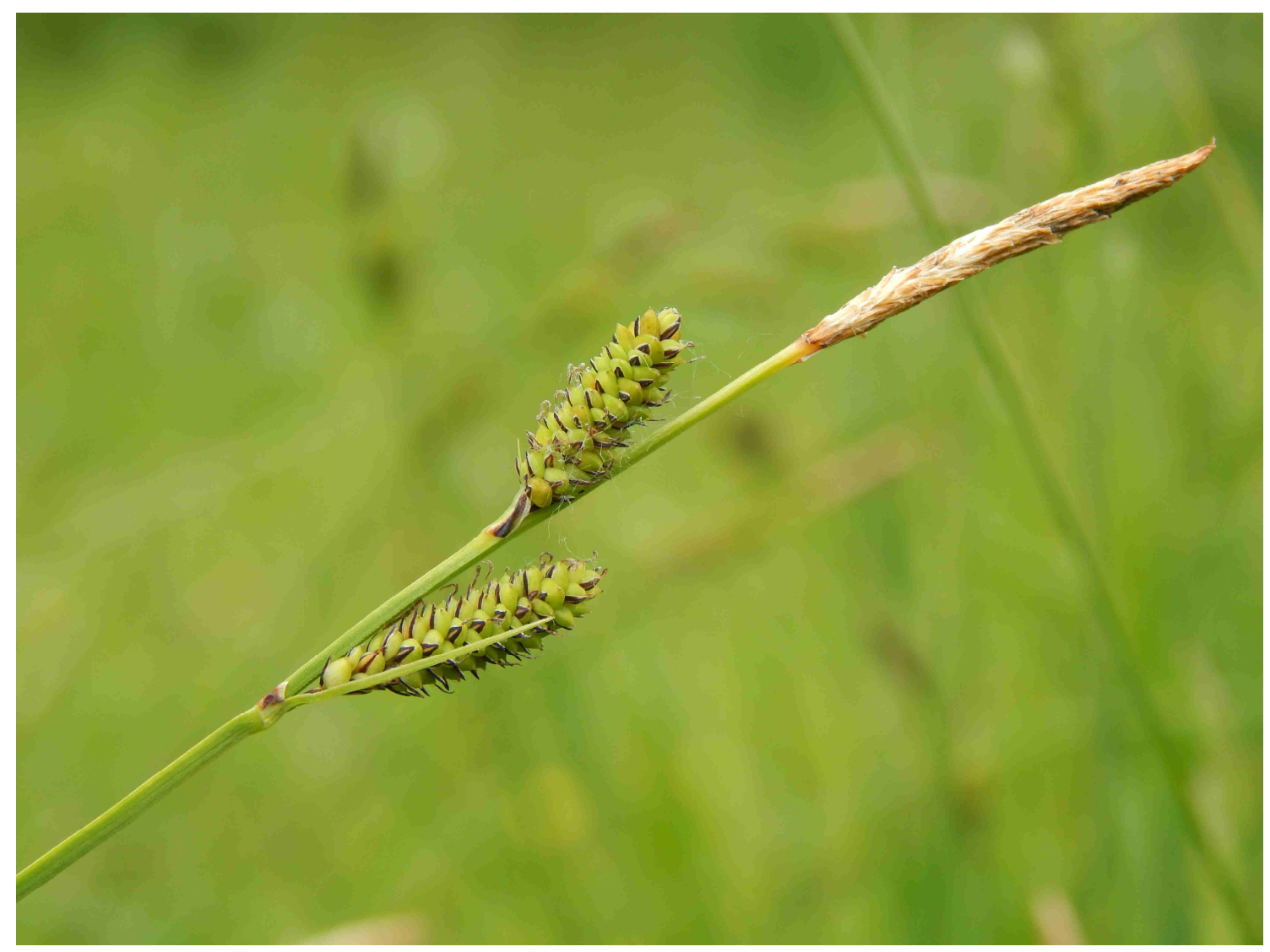

e34. ábra Carex cespitosa, Nyíracsád, Jónásrész, 2017

Fig. e34 Carex cespitosa, Nyíracsád, Jónásrész, 2017 


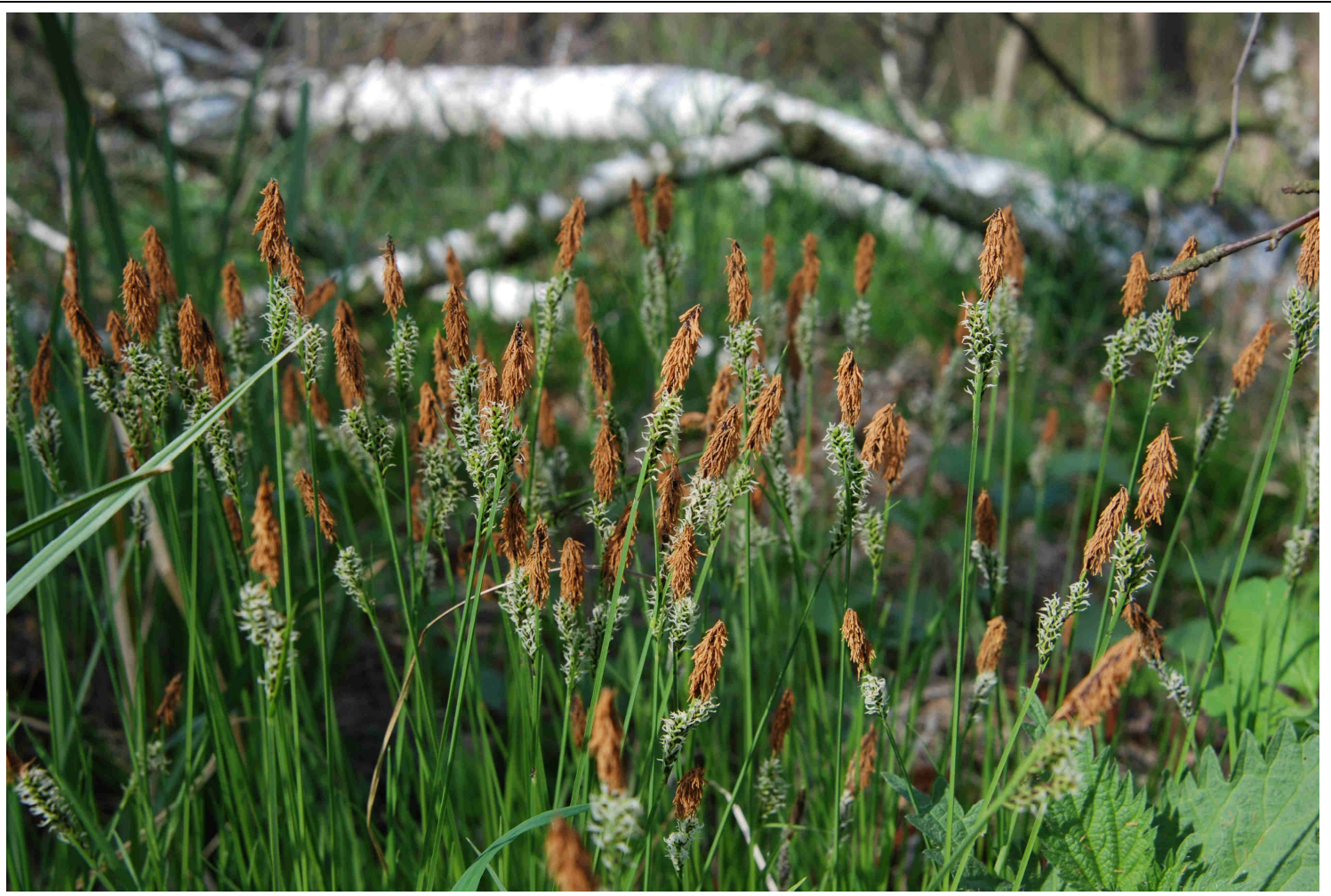

e35. ábra Carex cespitosa L. jellegzetes fahéjszínű porzói, Debrecen, Nagy-dűlő, 2014

Fig. e35 Carex cespitosa L.with characteristic cinnamon stamens, Debrecen, Nagy-dűlő, 2014

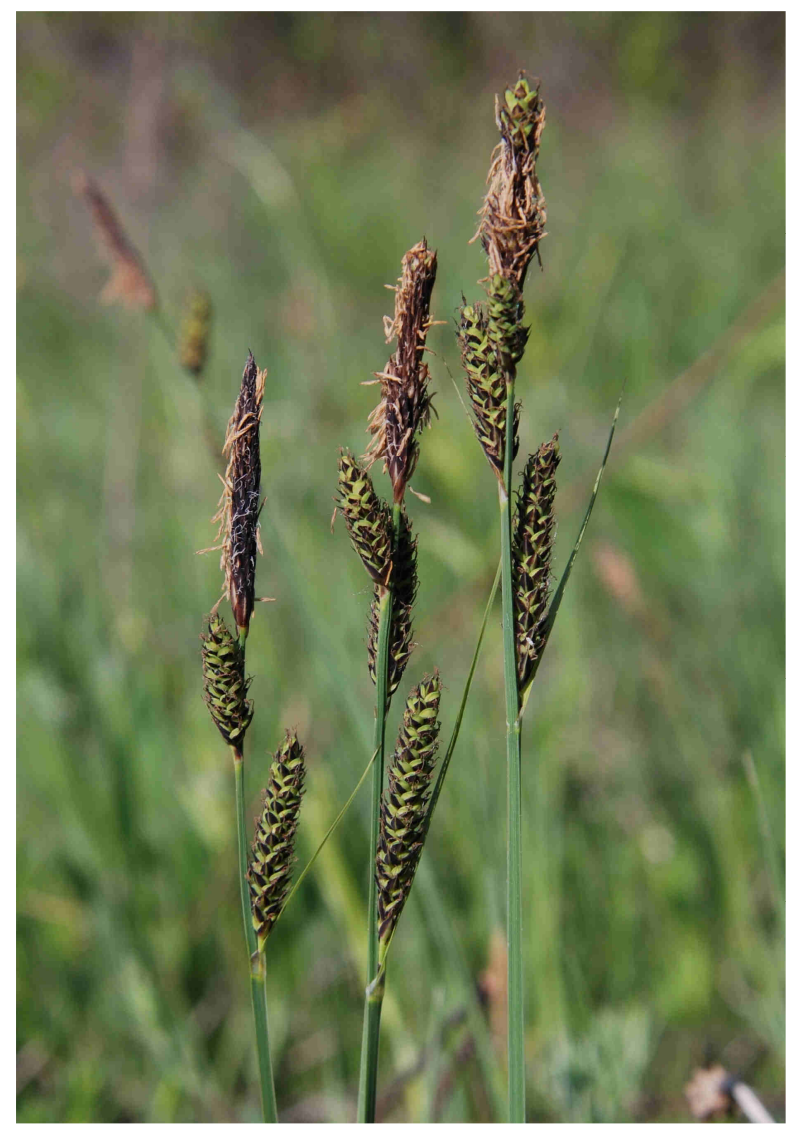

e36. ábra Carex hartmanii, Újléta, Hegyalja, 2011

Fig. e36 Carex hartmanii, Újléta, Hegyalja, 2011

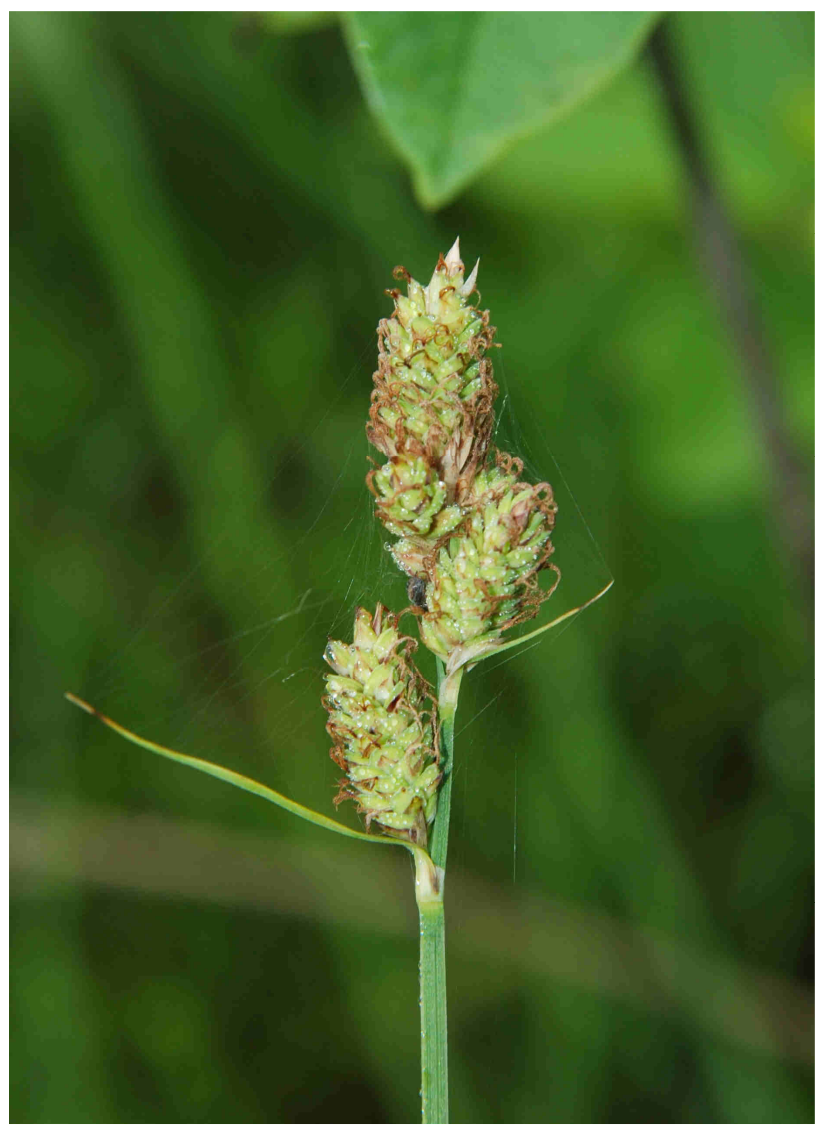

e37. ábra Carex hartmanii, Újléta, Hegyalja, 2010

Fig. e37 Carex hartmanii, Újléta, Hegyalja, 2010 


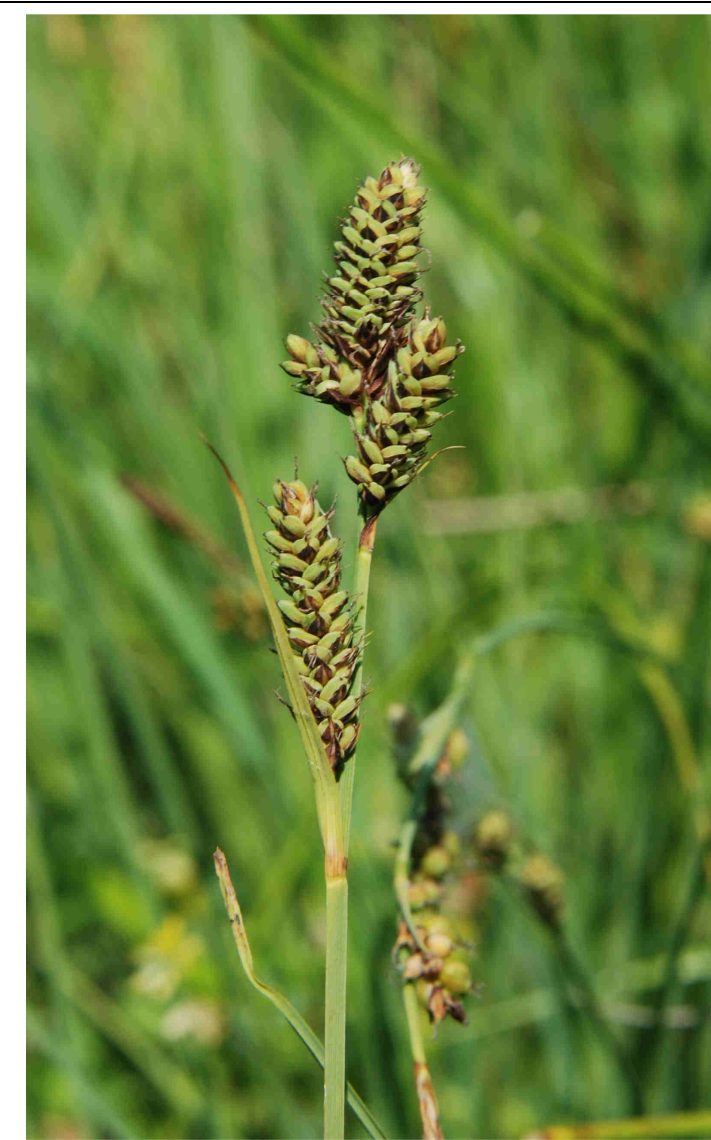

e38. ábra Carex hartmanii, Nyírmártonfalva, Lapos-dűlő, 2011

Fig. e38 Carex hartmanii, Nyírmártonfalva, Lapos-dűlő, 2011

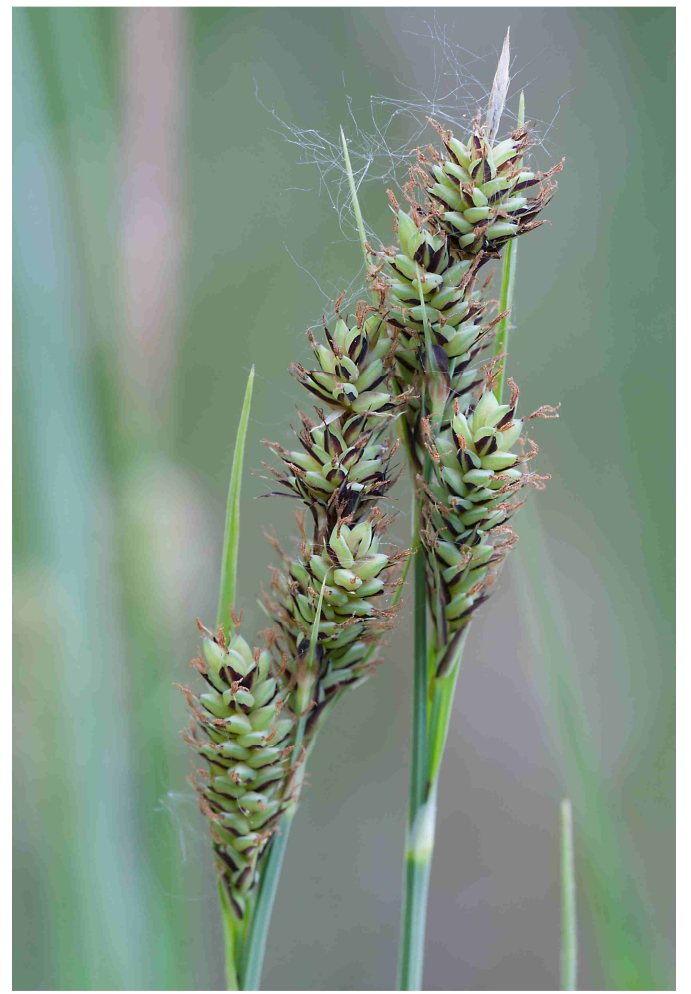

e40. ábra Carex buxbaumii, Vámospércs, Kőrises-dűlő (Jónásrész), 2012

Fig. e40 Carex buxbaumii, Vámospércs, Kőrises-dűlő (Jónásrész), 2012

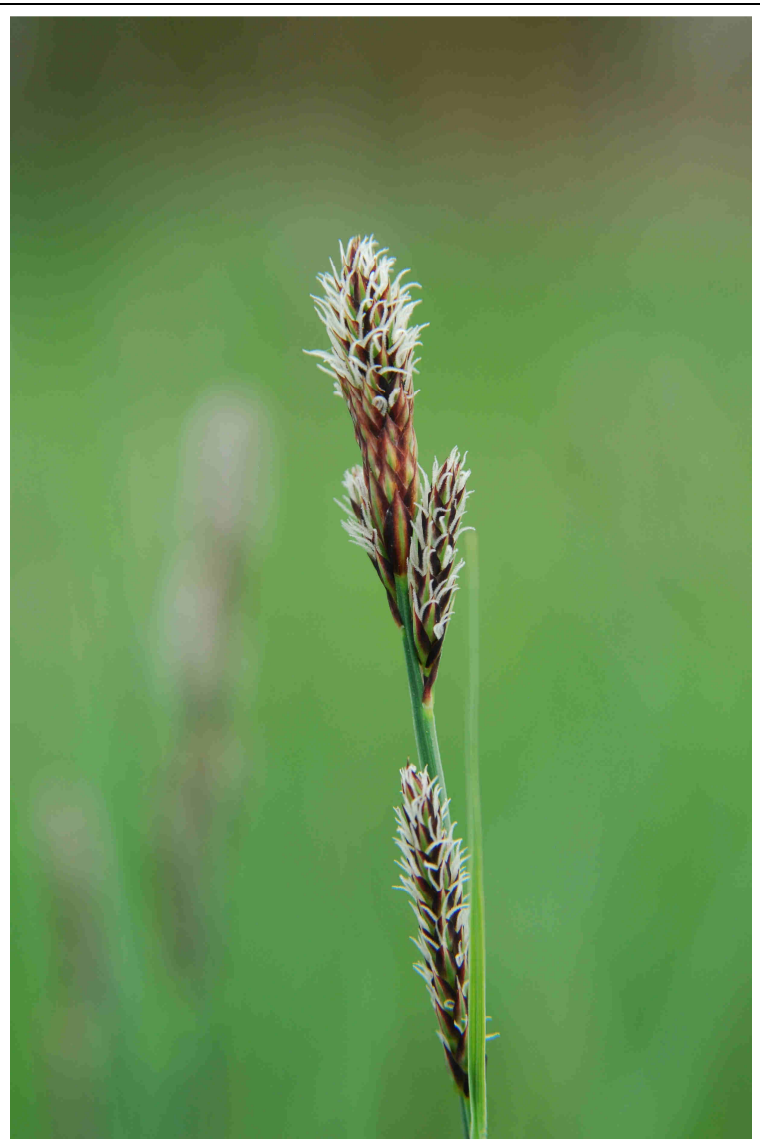

e39. ábra Carex hartmanii, Debrecen, Nagycsere, 2018 Fig. e39 Carex hartmanii, Debrecen, Nagycsere, 2018

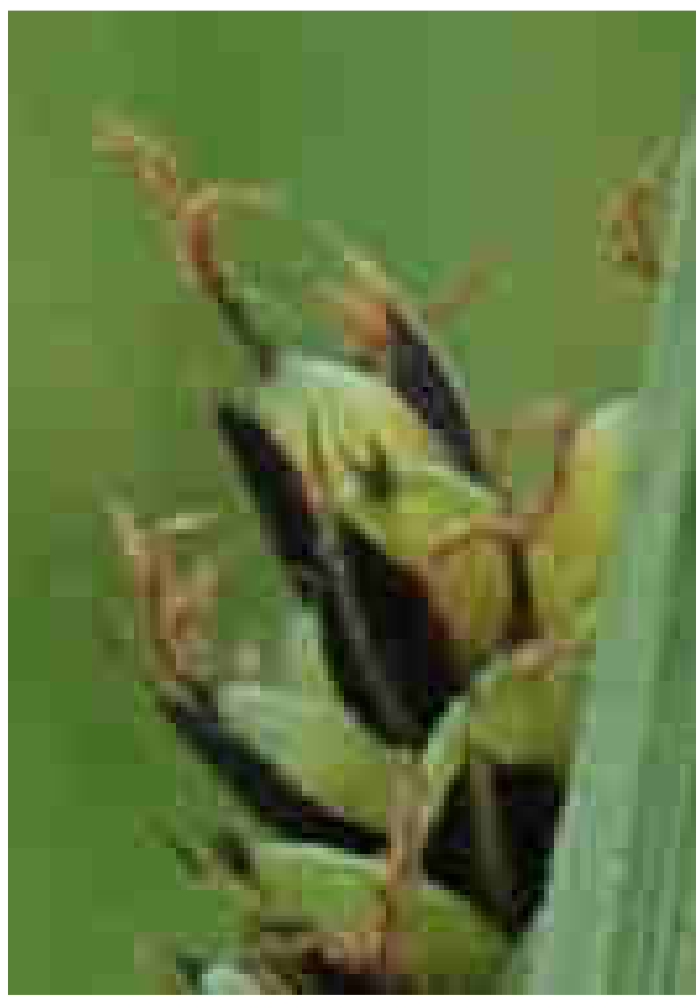

e41. ábra Carex buxbaumii tömlőcskéjének csőre,

Vámospércs, Kőrises-dűlő (Jónásrész), 2011

Fig. e41 Beak of utricle of Carex buxbaumii, Vámospércs, Kőrises-dűlő (Jónásrész), 2011 


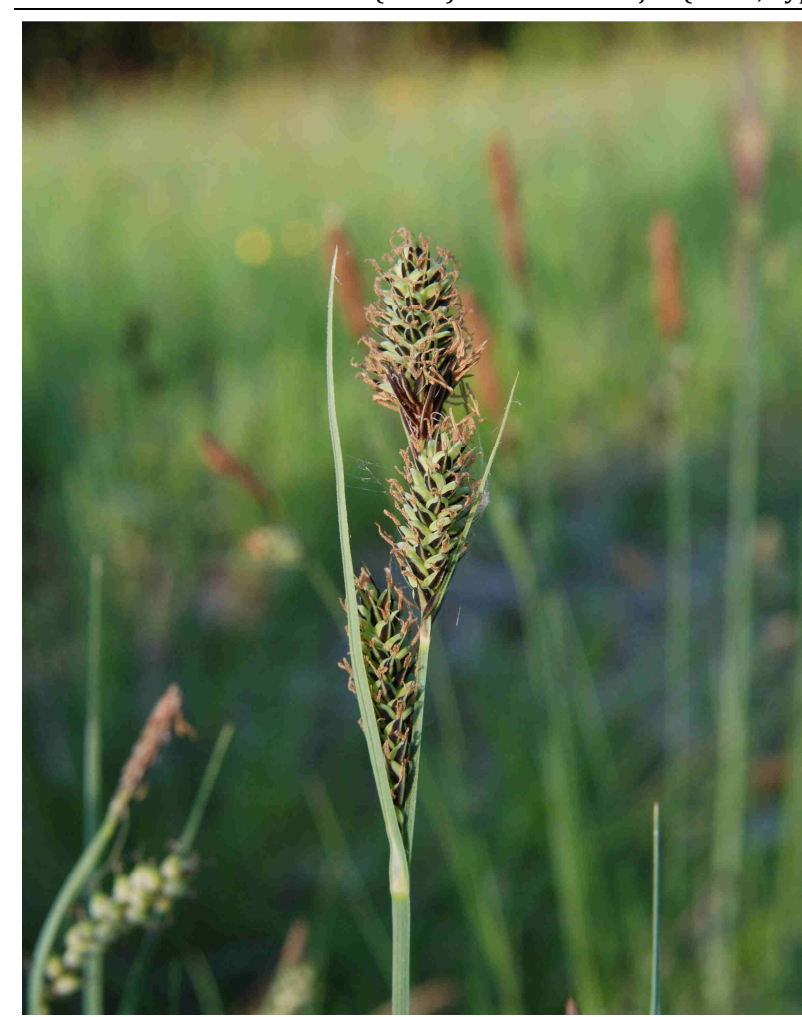

e42. ábra Carex buxbaumii, Vámospércs, Kőrises-dűlő (Jónásrész), 2011

Fig. e42 Carex buxbaumii, Vámospércs, Kőrises-dűlő (Jónásrész), 2011

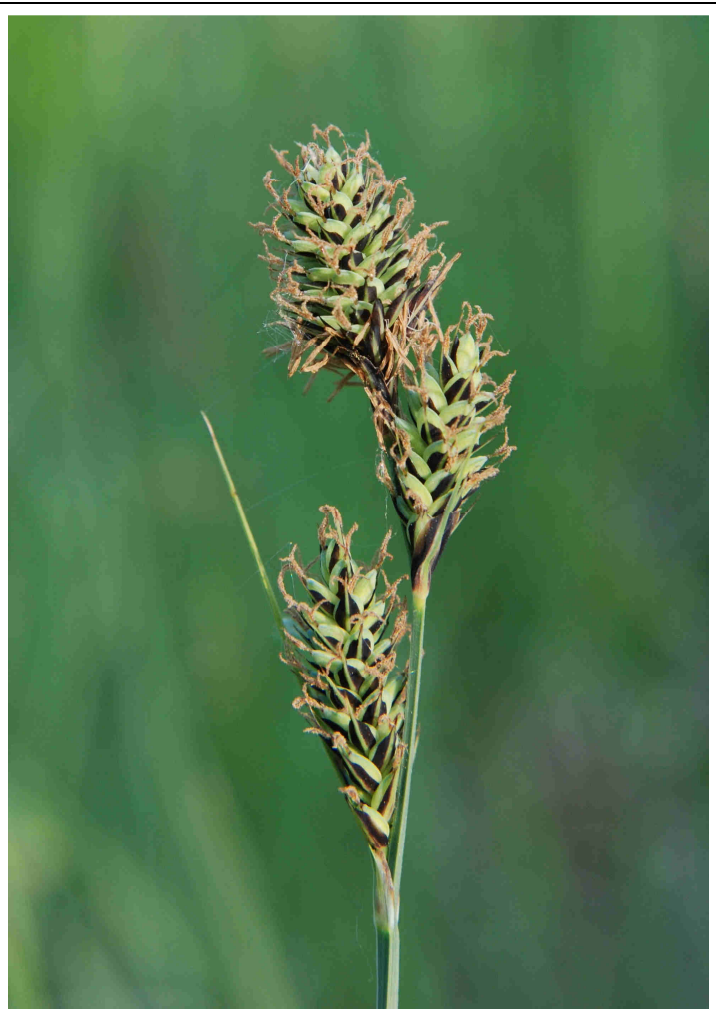

e43. ábra Carex buxbaumii, Vámospércs, Kőrises-dűlő (Jónásrész), 2011

Fig. e43 Carex buxbaumii, Vámospércs, Kőrises-dűlő (Jónásrész), 2011

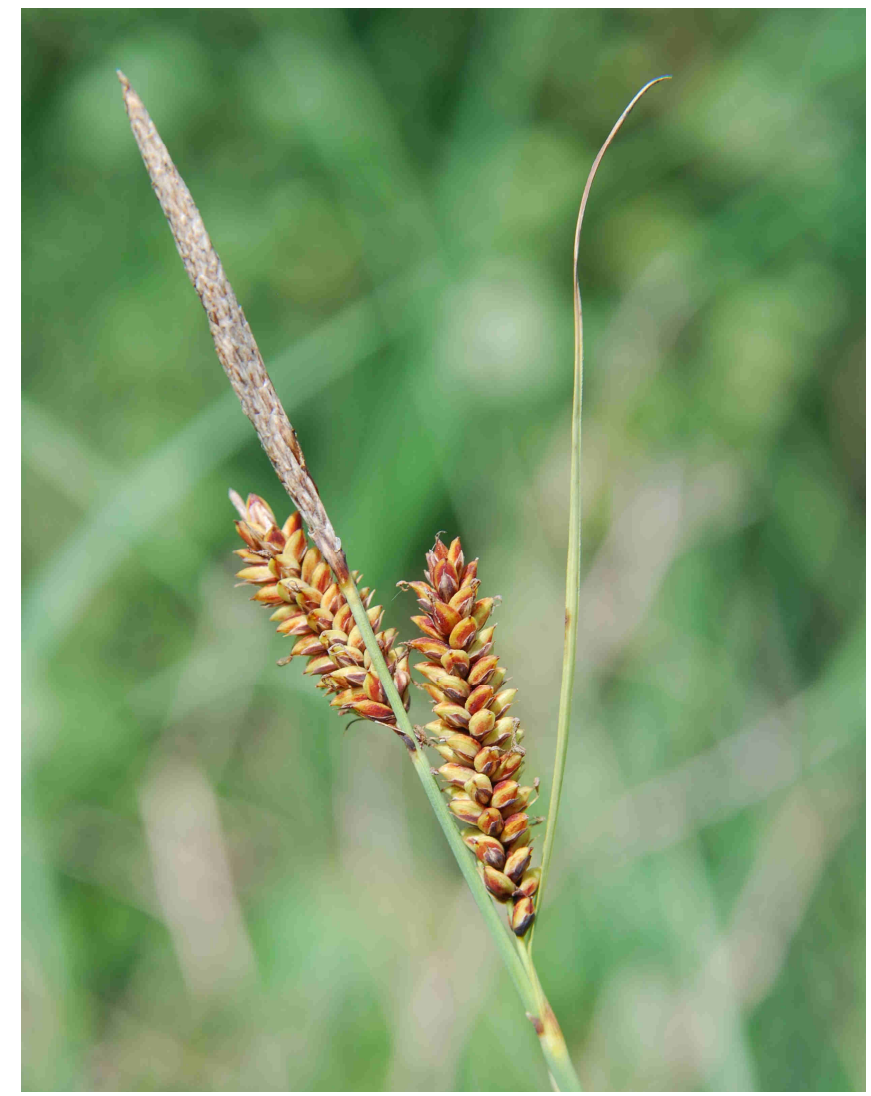

e44. ábra Carex flacca, Monostorpályi, Monostorpályi-legelő, 2019

Fig. e44 Carex flacca, Monostorpályi, Monostorpályi-legelő, 2019 


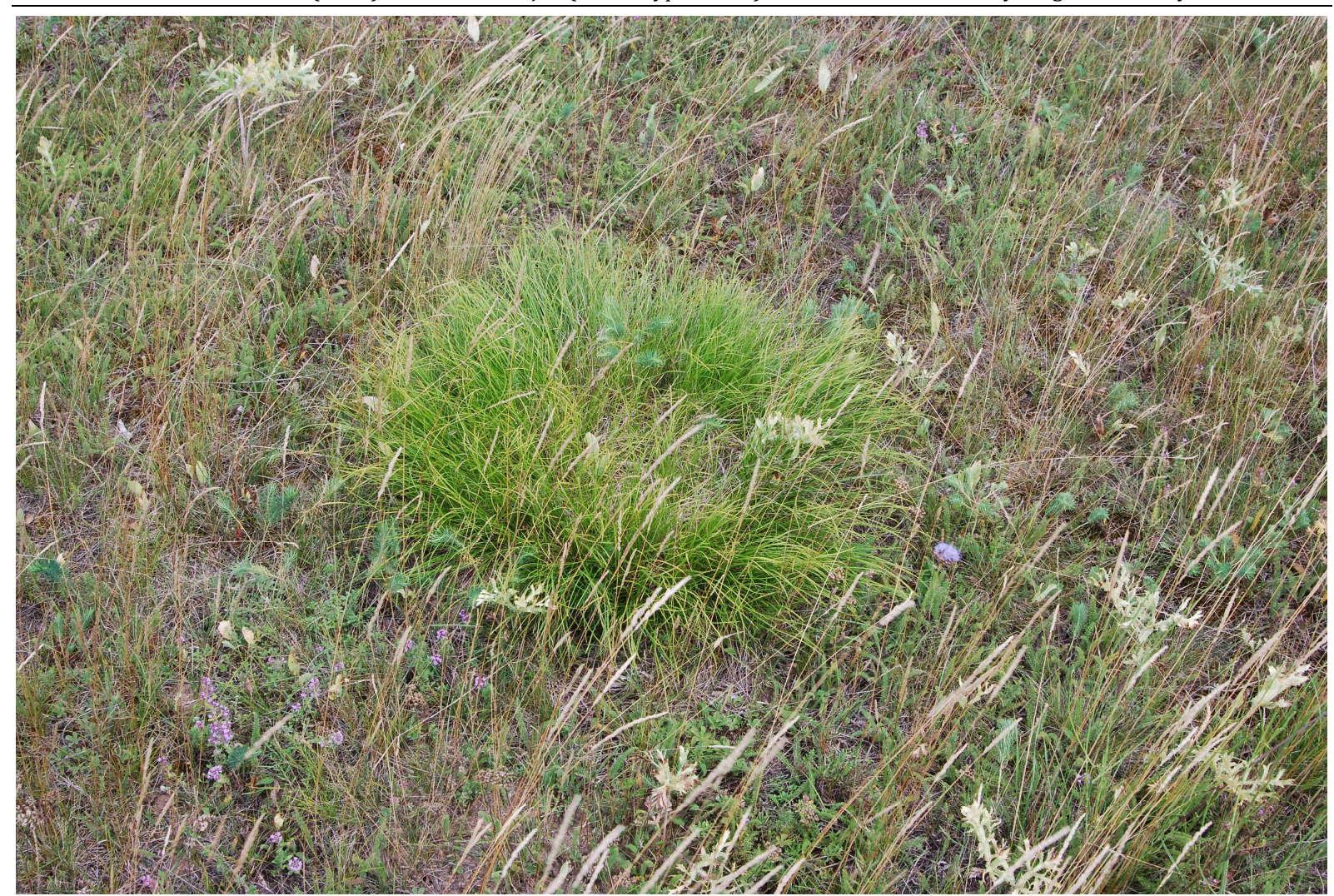

e45. ábra Carex humilis, Bagamér, Malomgát (Daru-hegyek), 2015

Fig. e45 Carex humilis, Bagamér, Malomgát (Daru-hegyek), 2015

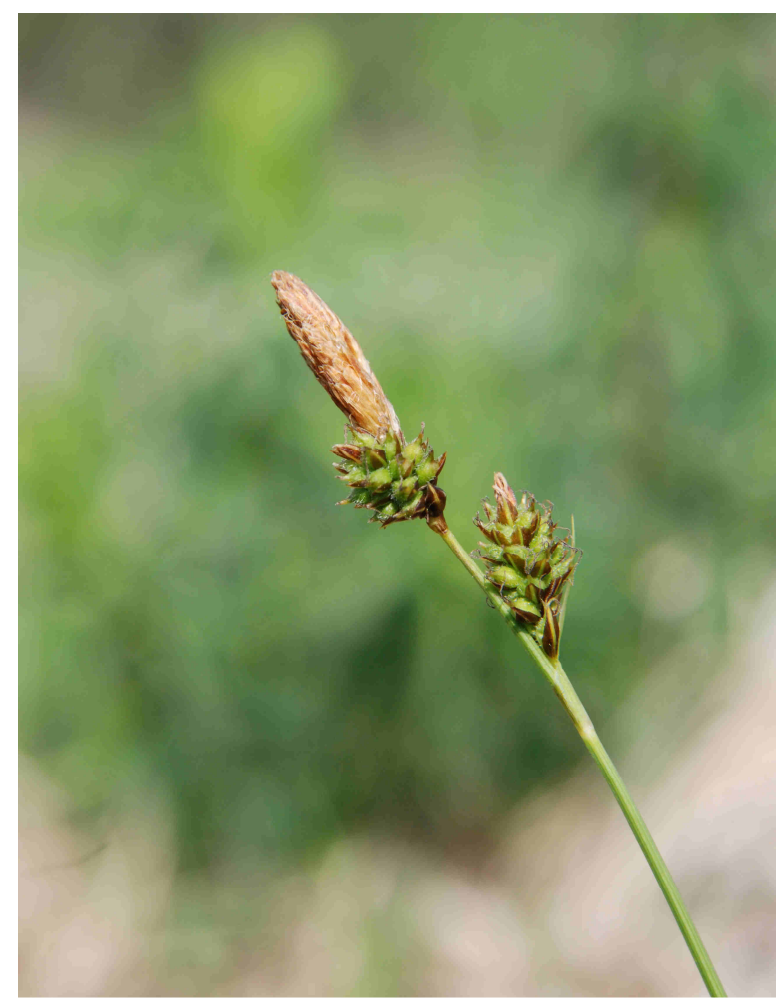

e46. ábra Carex umbrosa, Nyírábrány, Káposztás-lapos, 2010

Fig. e46 Carex umbrosa, Nyírábrány, Káposztás-lapos, 2010

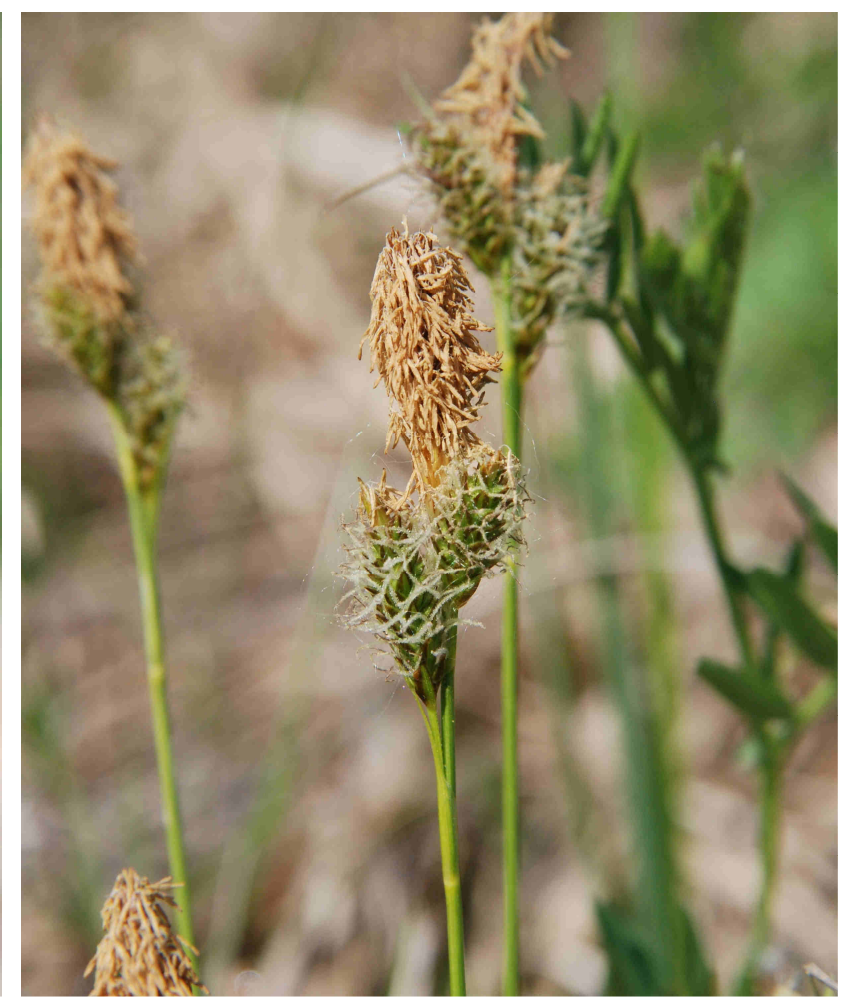

e47. ábra Carex umbrosa, Újléta, Bank-lapos, 2011 Fig. e47 Carex umbrosa, Újléta, Bank-lapos, 2011 


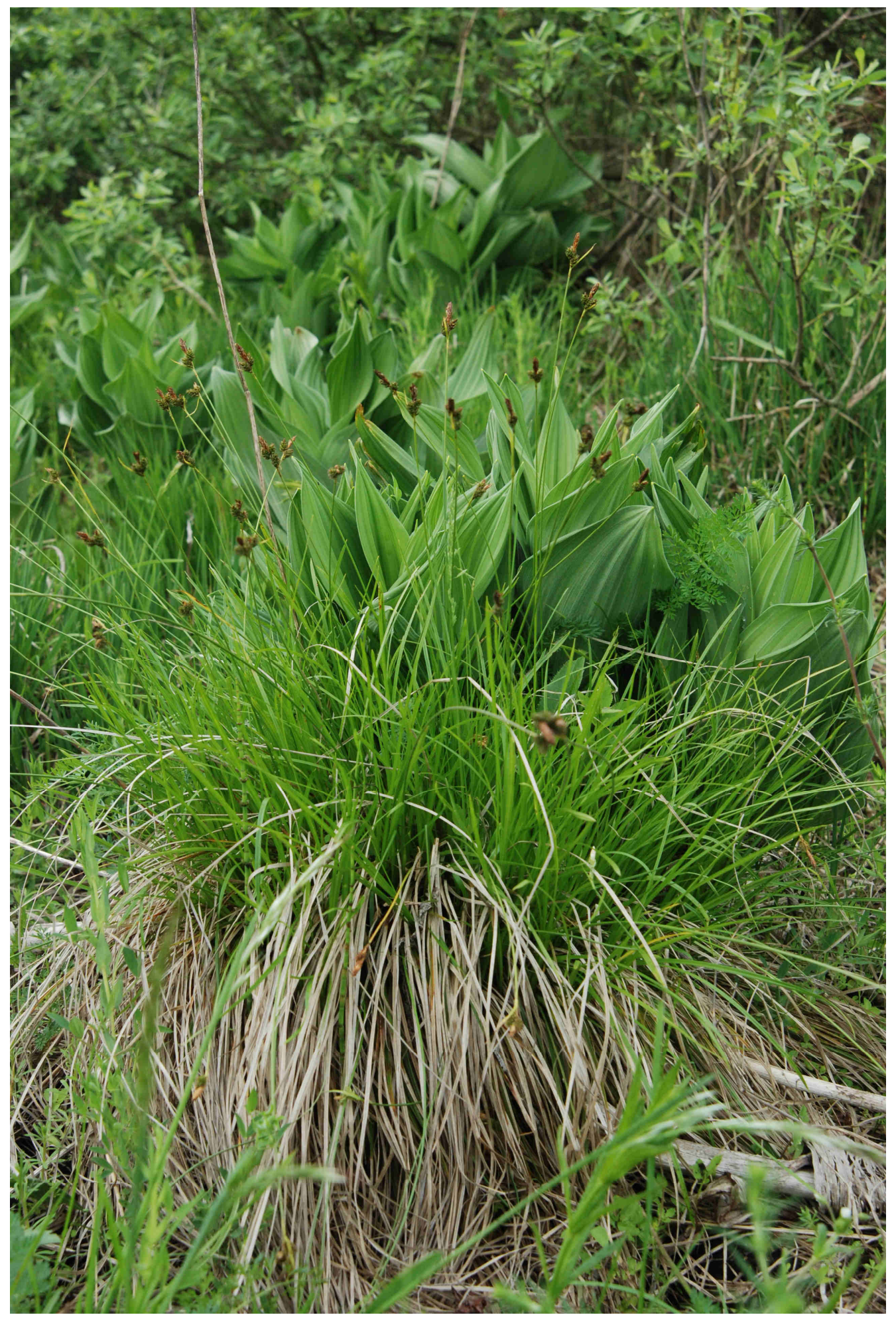

e48. ábra Carex umbrosa, Bagamér, Silye-rét, 2010

Fig. e48 Carex umbrosa, Bagamér, Silye-rét, 2010 


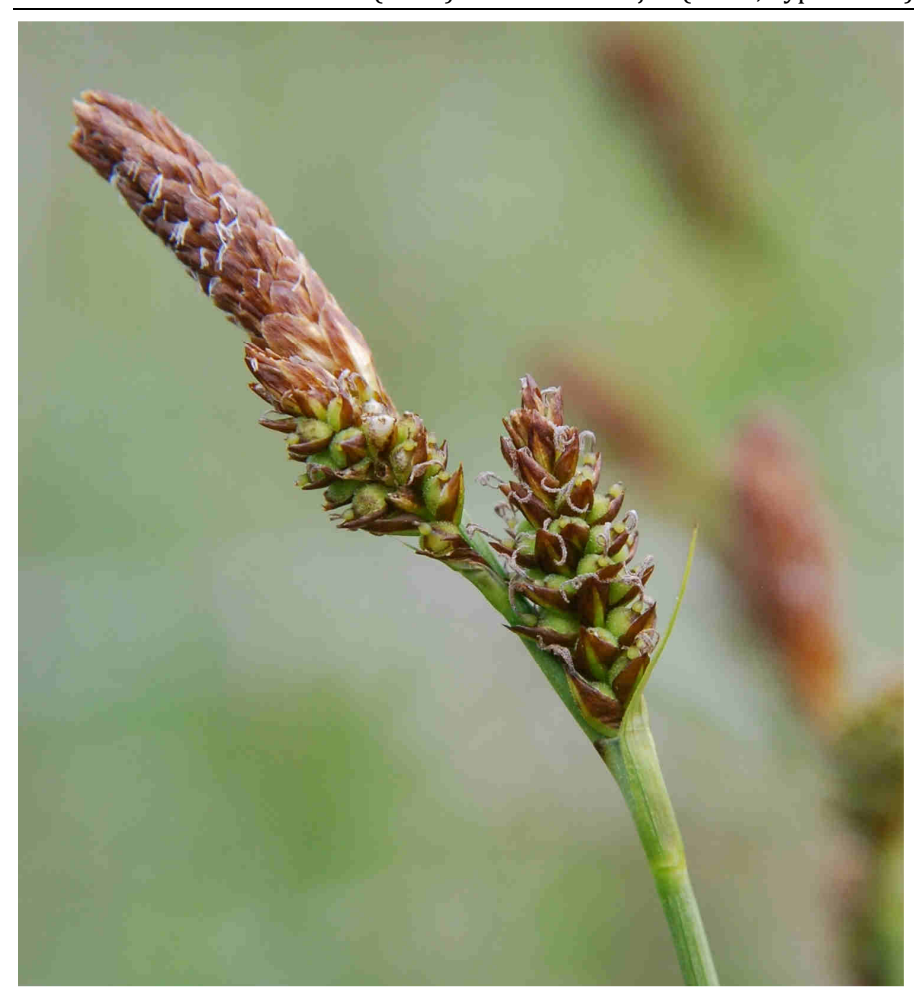

e49. ábra Carex caryophyllea, Bagamér, Malomgát (Daru-hegyek), 2017

Fig. e49 Carex caryophyllea, Bagamér, Malomgát (Daru-hegyek), 2017

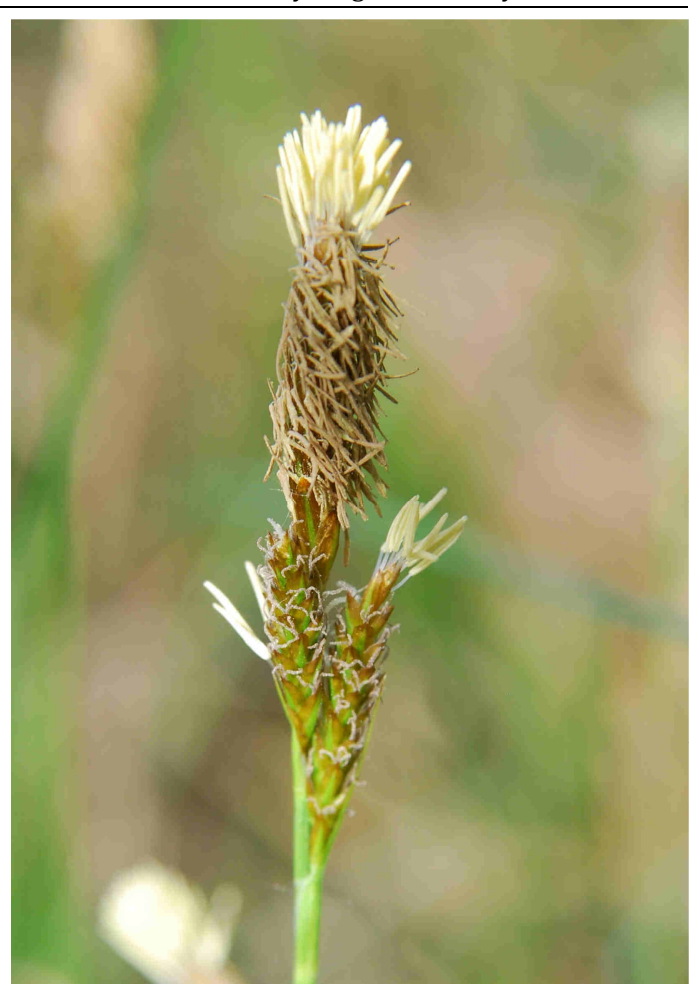

e50. ábra Carex caryophyllea, Debrecen, Bánki-erdő, 2016

Fig. e50 Carex caryophyllea, Debrecen, Bánki-erdő, 2016

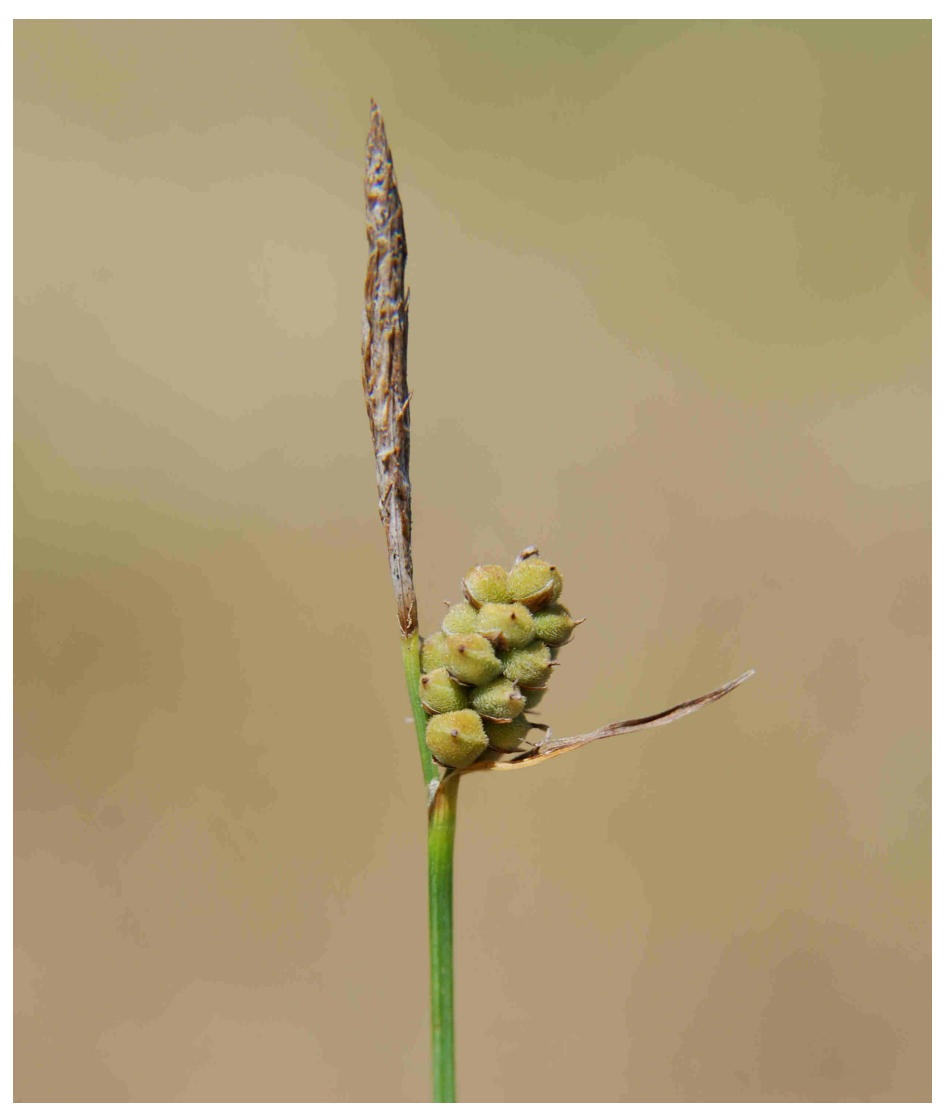

e51. ábra Carex tomentosa, Monostorpályi, Leány-tó, 2019

Fig. e51 Carex tomentosa, Monostorpályi, Leány-tó, 2019 


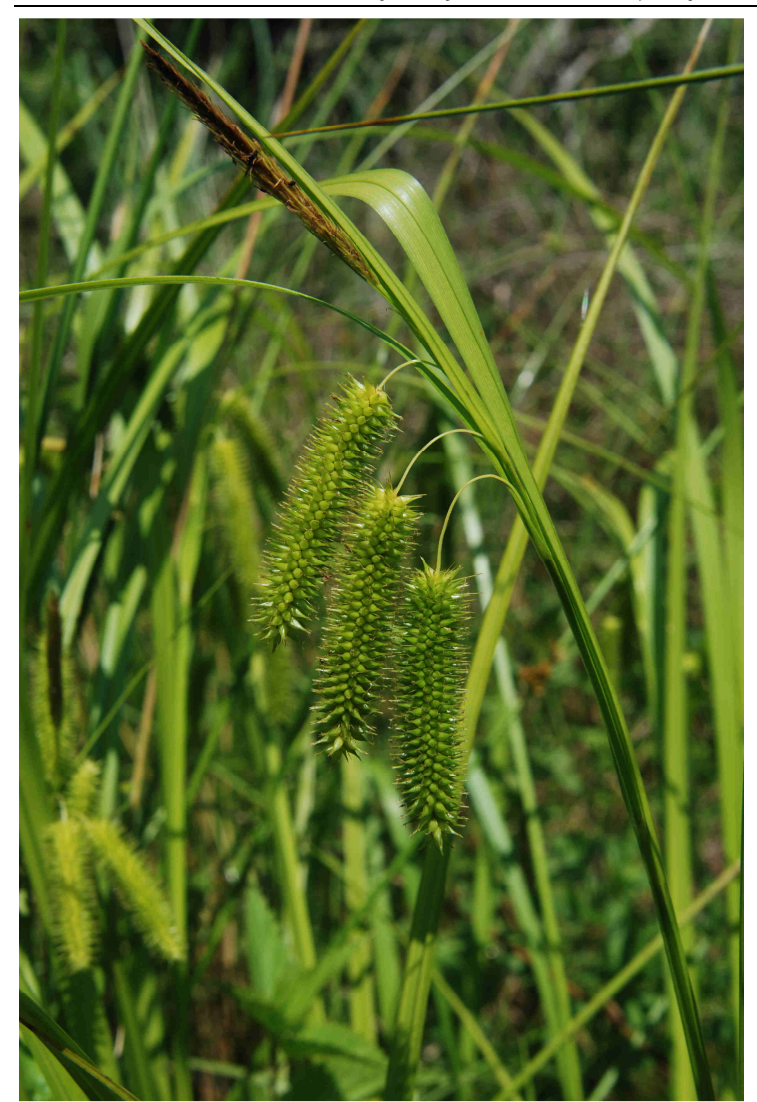

e52. ábra Carex pseudocyperus, Nyírmártonfalva, Lapos-dúlő, 2011

Fig. e52 Carex pseudocyperus, Nyírmártonfalva, Lapos-dúlő, 2011

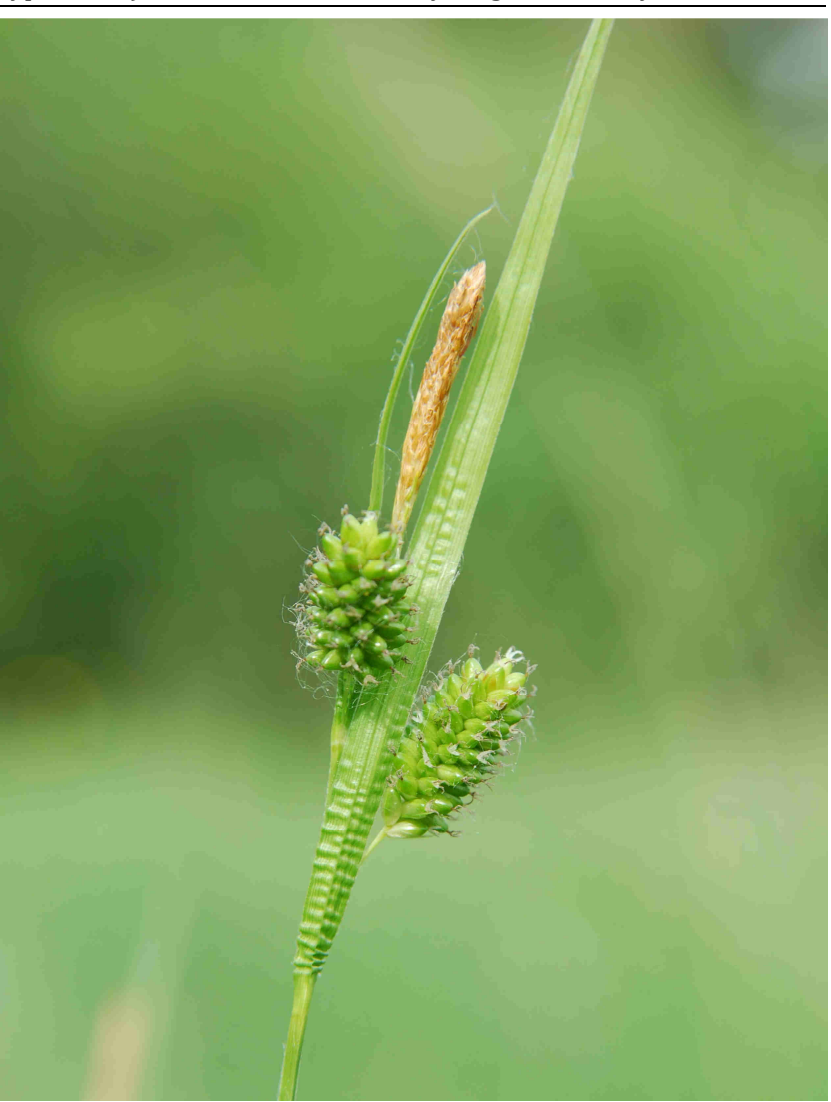

e53. ábra Carex pallescens, Monostorpályi, Monostorpályi-legelő, 2019

Fig. e53 Carex pallescens, Monostorpályi, Monostorpályi-legelő, 2019

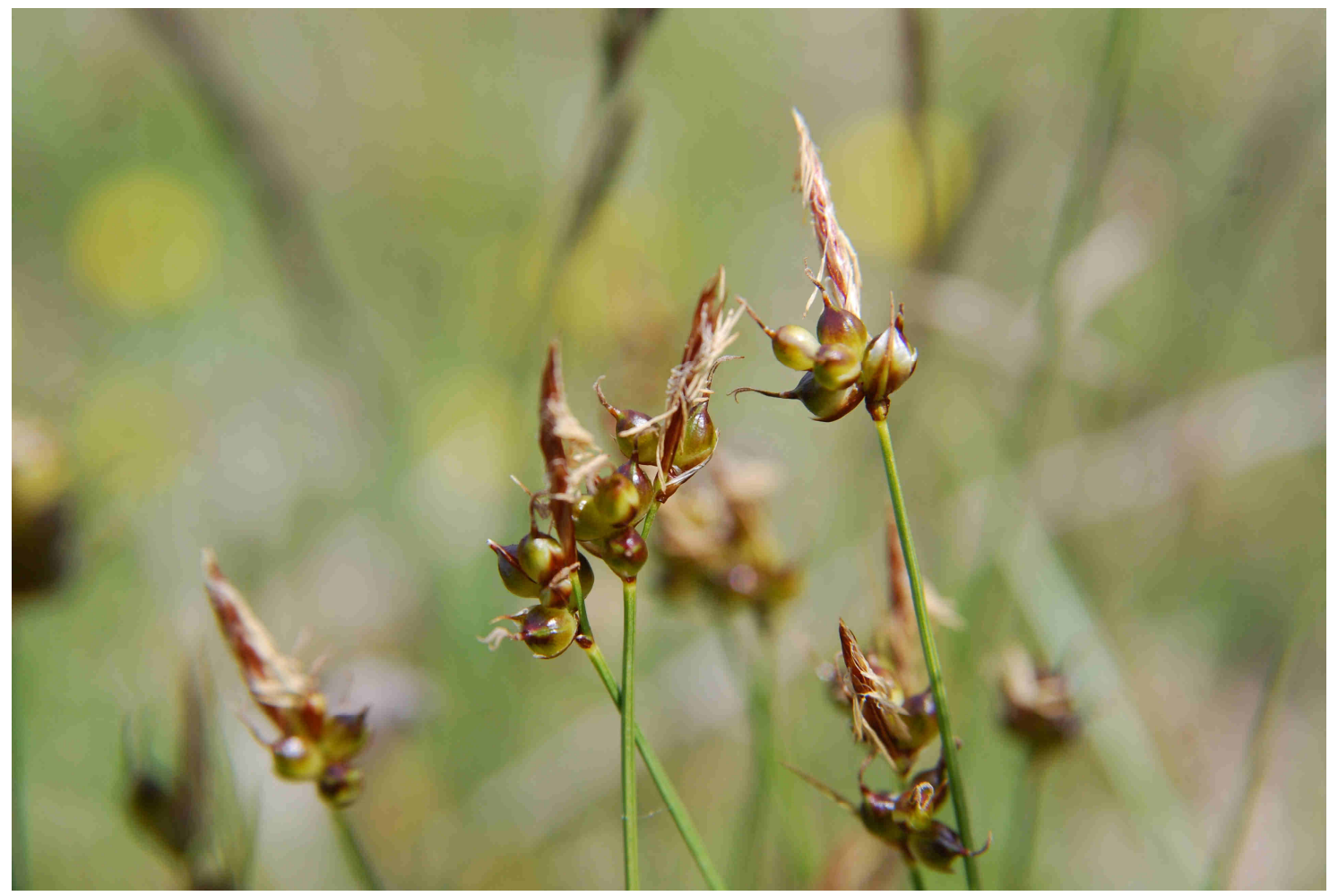

e54. ábra Carex supina, Bagamér, Malomgát (Daru-hegyek), 2017

Fig. e54 Carex supina, Bagamér, Malomgát (Daru-hegyek), 2017 


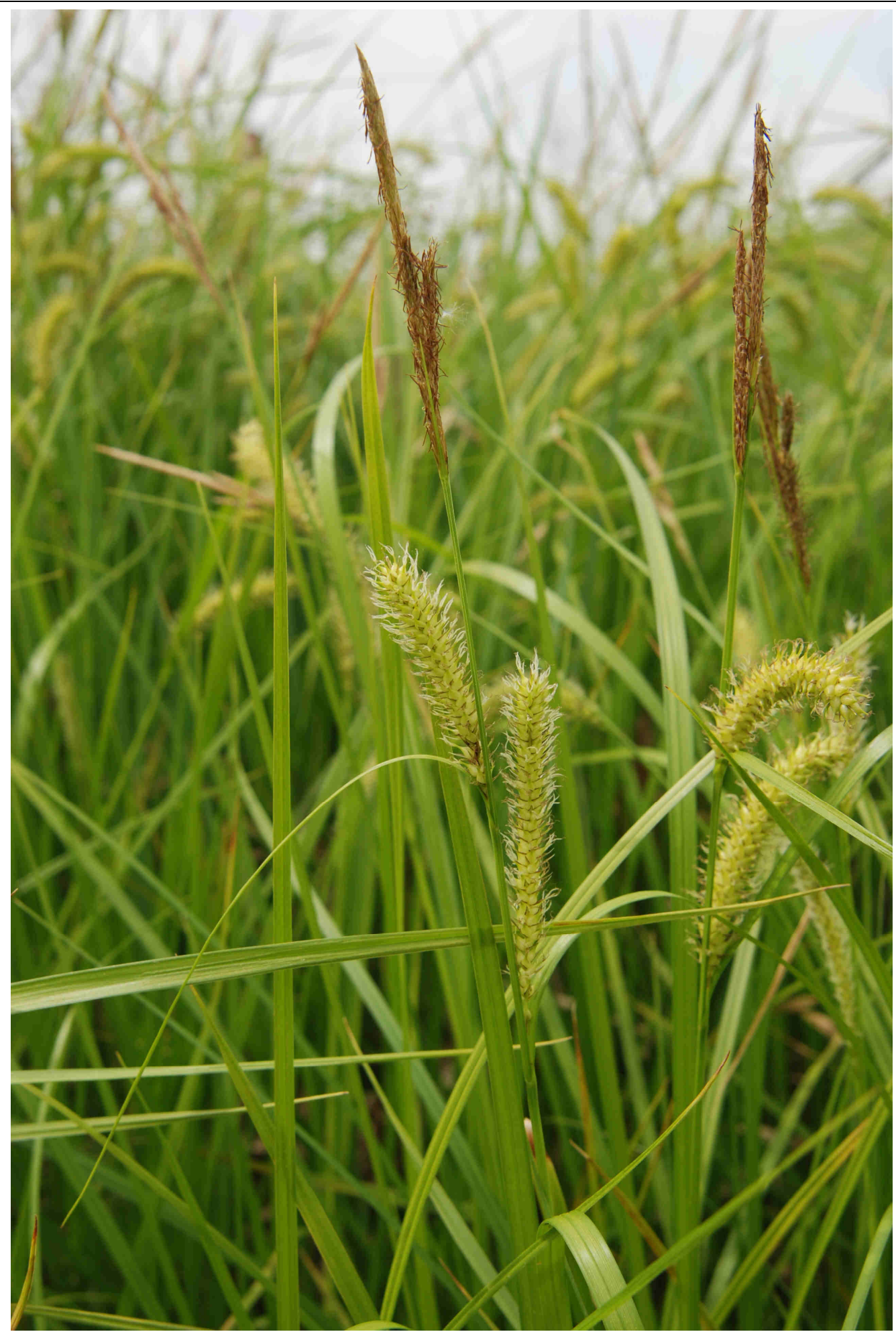

e55. ábra Carex vesicaria, Fülöp, Százholdas, 2013

Fig. e55 Carex vesicaria, Fülöp, Százholdas, 2013 


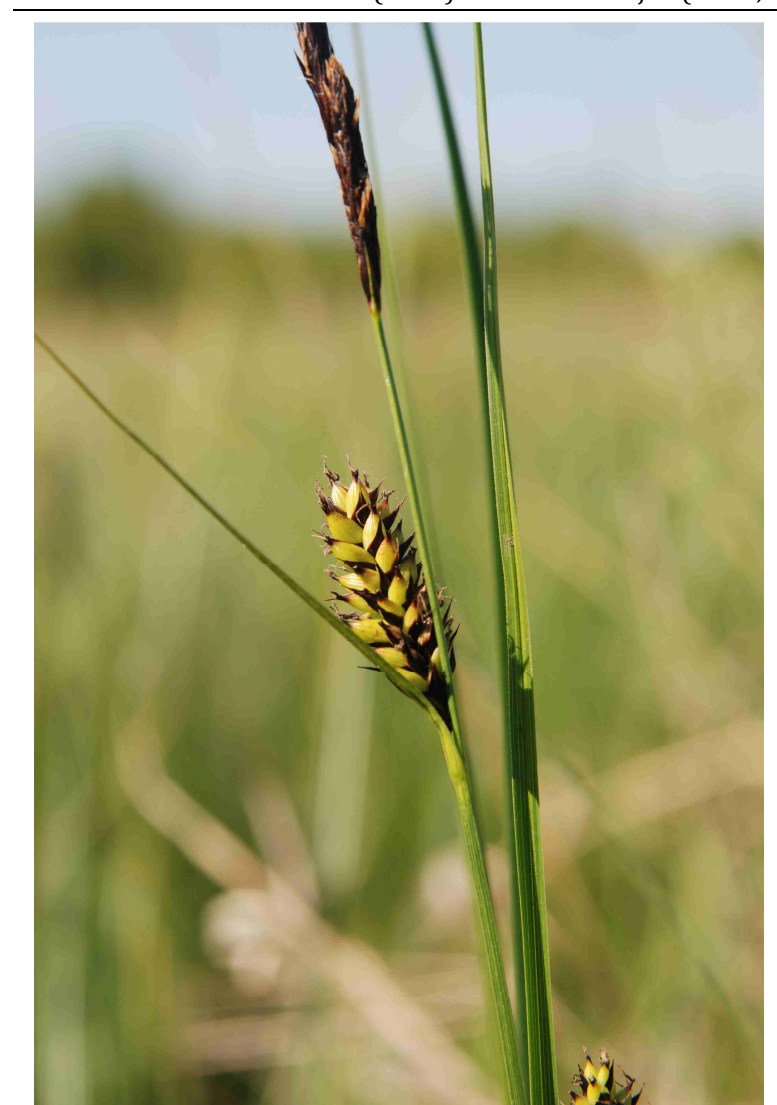

e56. ábra Carex melanostachya, Hajdúbagos, Földikutya Rezervátum, 2011

Fig. e56 Carex melanostachya, Hajdúbagos, Földikutya Rezervátum, 2011

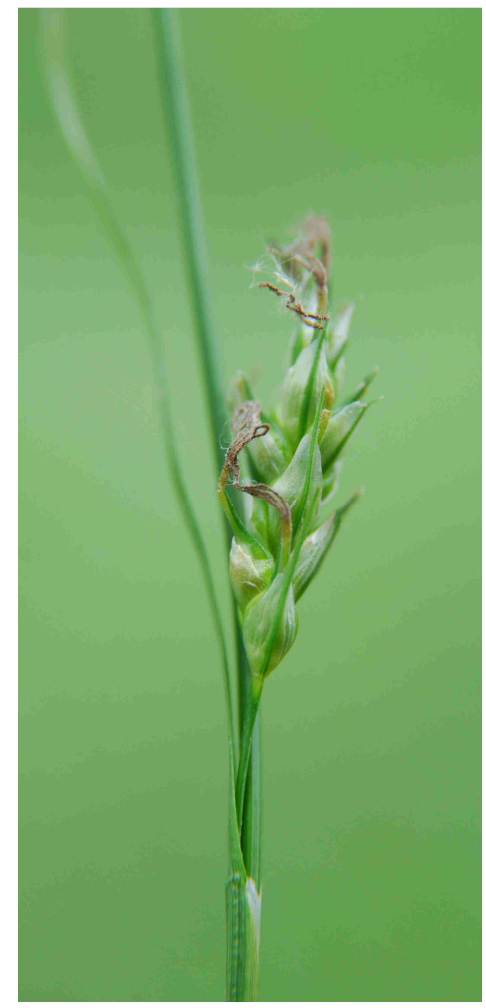

e58. ábra Carex michelii, Nyíracsád, Jónásrész, 2019 Fig. e58 Carex michelii, Nyíracsád, Jónásrész, 2019

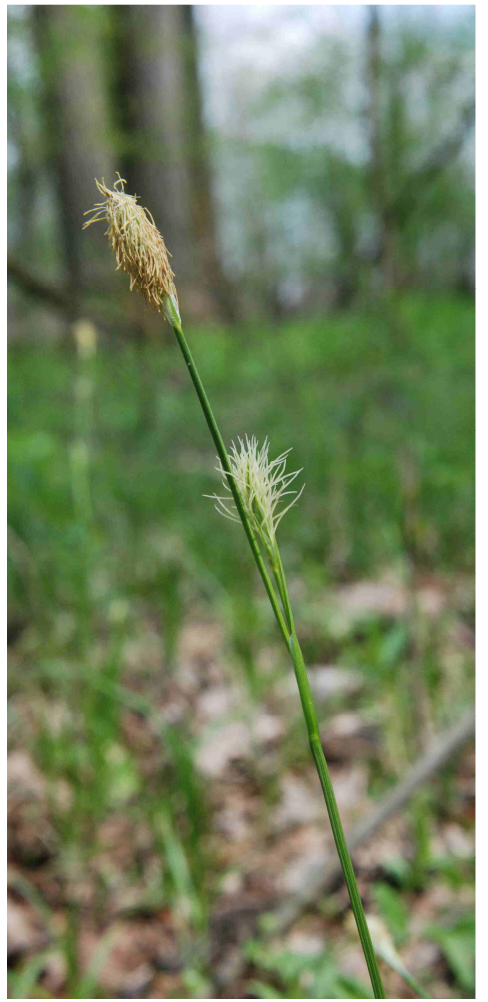

e59. ábra Carex michelii,

Debrecen, Nagy-tag, 2013

Fig. e59 Carex michelii, Debrecen, Nagy-tag, 2013

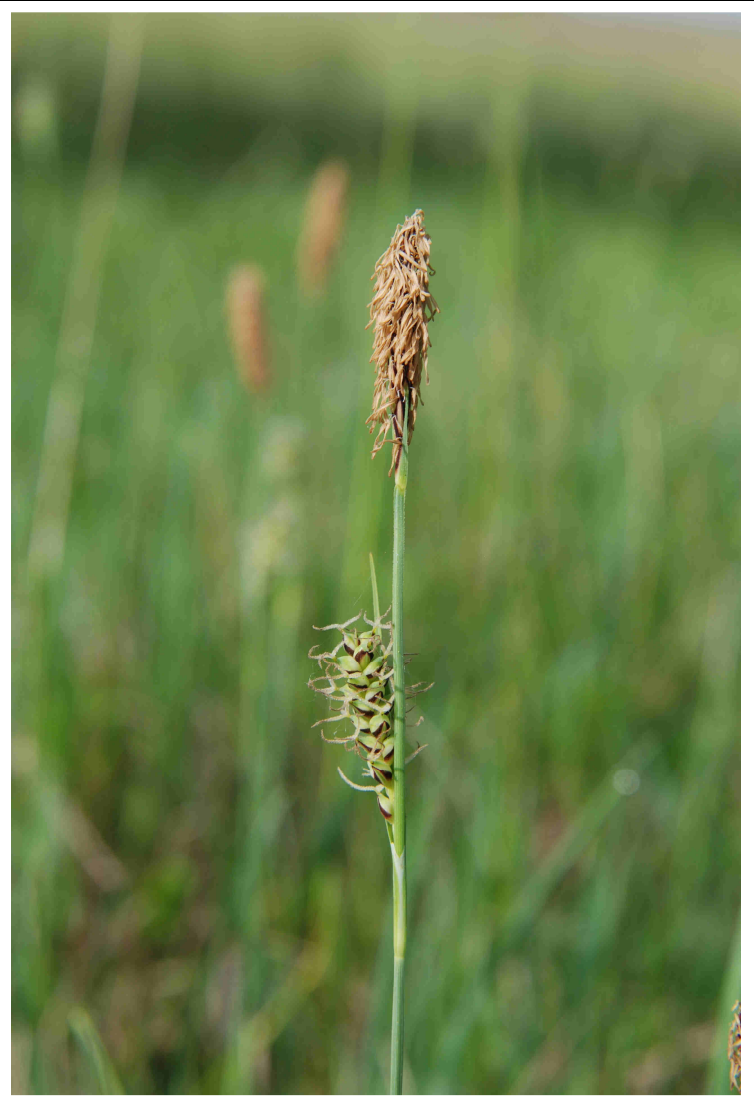

e57. ábra Carex panicea, Hajdúsámson, Martinkai-legelő, 2013

Fig. e57 Carex panicea, Hajdúsámson, Martinkai-legelő, 2013

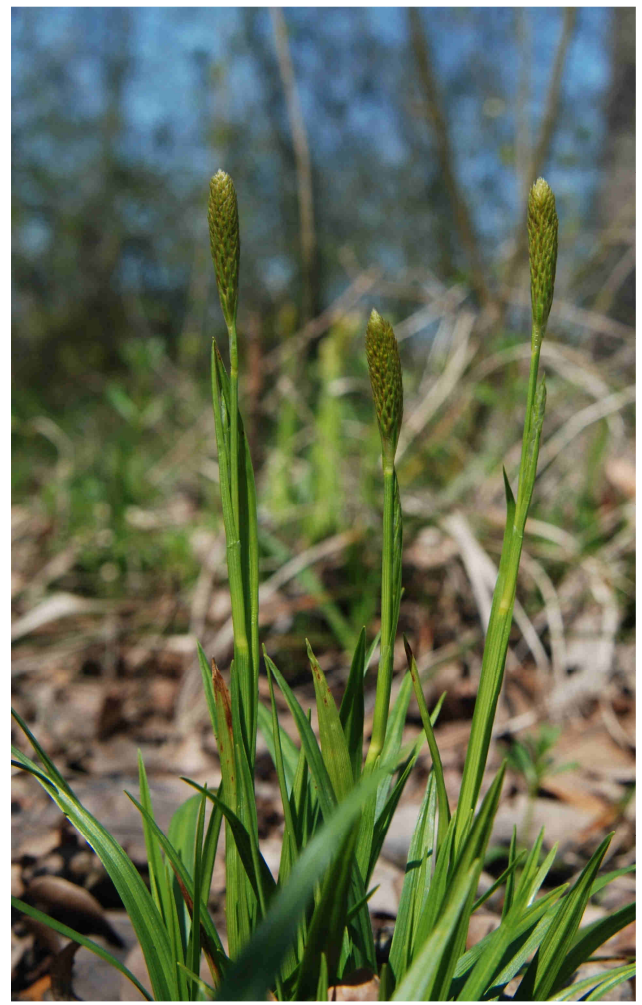

e60. ábra Carex michelii, Debrecen, Halápi-erdő, 2013

Fig. e60 Carex michelii, Debrecen, Halápi-erdő, 2013 


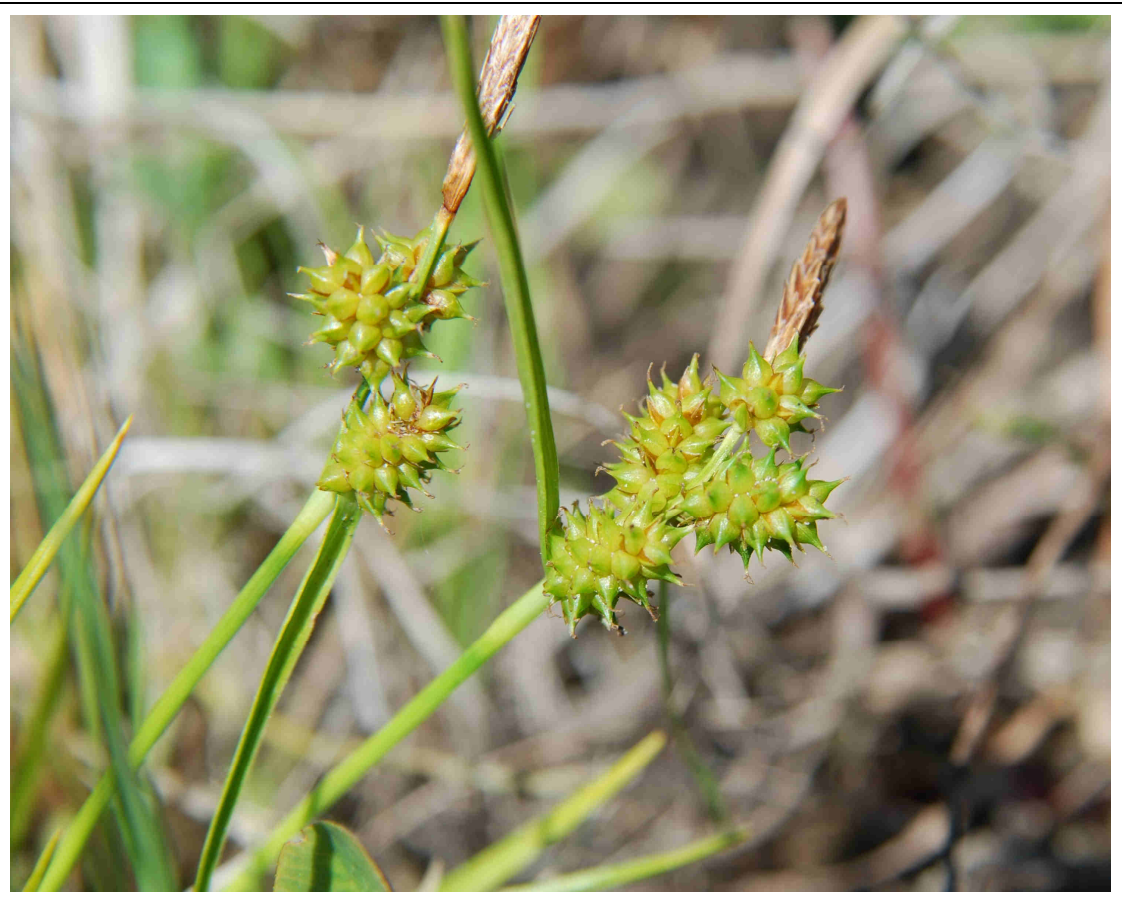

e61. ábra Carex viridula, Debrecen, Halápi-tározó, 2020

Fig. e61 Carex viridula, Debrecen, Halápi-tározó, 2020

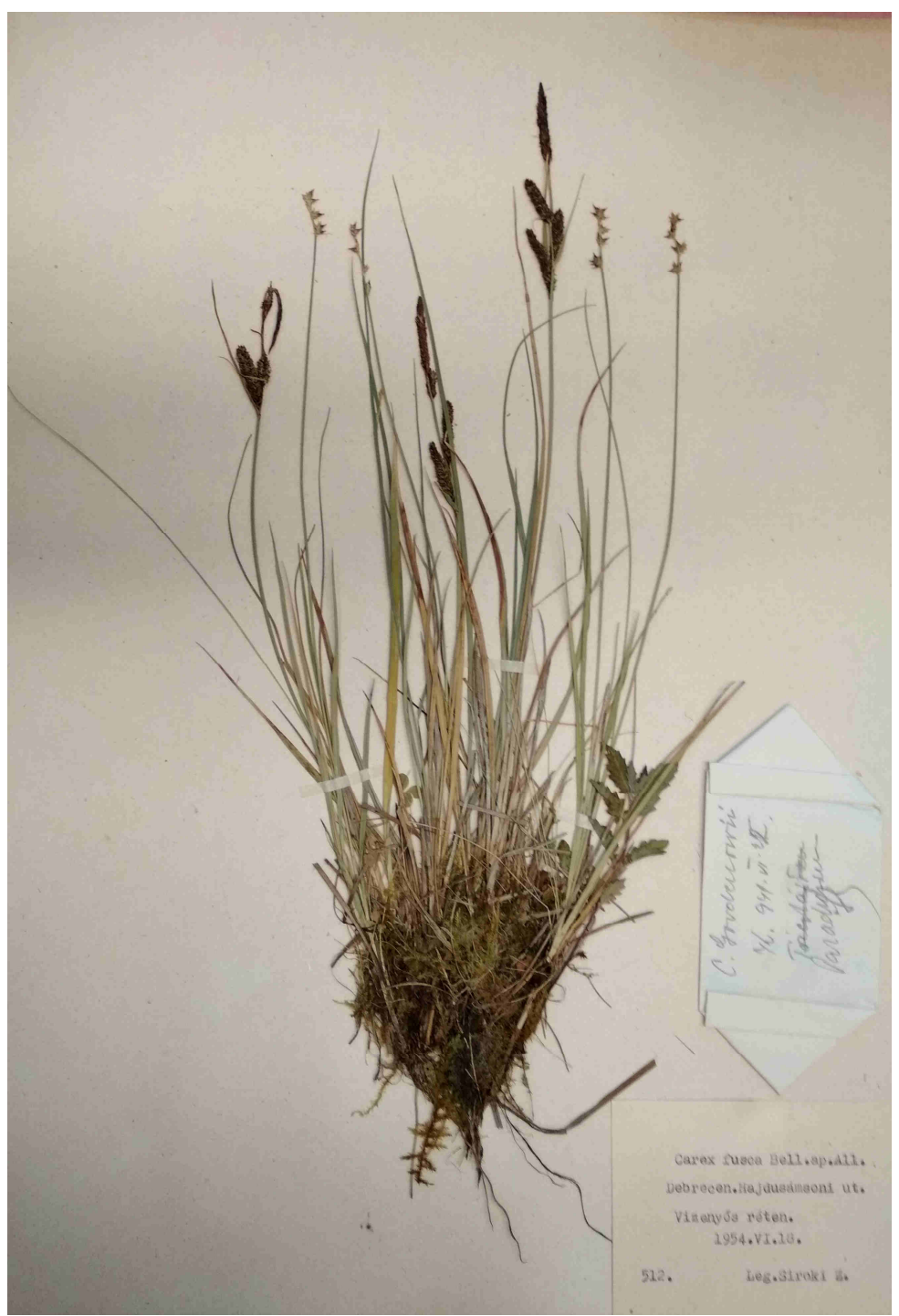

e62. ábra Siroki Zoltán herbáriumi lapja (DE) 1954-ből, melyen a Carex nigra és Carex echinata együtt látható Fig. e62 Zoltán Siroki's herbarium specimen (DE) from 1954, in which Carex nigra and Carex echinata can be seen together 